Rafael Rocha de Andrade

\title{
MONITORAMENTO ECOCARDIOGRÁFICO DA MIOCARDIOPATIA AUTOIMUNE DE AVES SINGÊNICAS INFECTADAS \\ EXPERIMENTALMENTE COM TRYPANOSOMA CRUZI E SUBMETIDAS AO TRANSPLANTE DE MEDULA ÓSSEA
}

\section{BRASÍLIA-DF \\ 2016}



UNIVERSIDADE DE BRASILIA - UNB

FACULDADE DE MEDICINA

PROGRAMA DE PÓS GRADUÇÃO EM CIÊNCIAS MÉDICAS

Rafael Rocha de Andrade

MONITORAMENTO ECOCARDIOGRÁFICO DA MIOCARDIOPATIA AUTOIMUNE DE AVES SINGÊNICAS INFECTADAS EXPERIMENTALMENTE COM TRYPANOSOMA CRUZI E SUBMETIDAS AO TRANSPLANTE DE MEDULA ÓSSEA 


\section{MONITORAMENTO ECOCARDIOGRÁFICO DA MIOCARDIOPATIA AUTOIMUNE DE AVES SINGÊNICAS \\ INFECTADAS EXPERIMENTALMENTE COM TRYPANOSOMA \\ CRUZIE SUBMETIDAS AO TRANSPLANTE DE MEDULA ÓSSEA}

Tese apresentada ao programa de Pós-

Graduação em Ciências Médicas da Faculdade de Medicina da Universidade de Brasília como requisito parcial à obtenção do grau de Doutor. Área de concentração: Medicina

Orientador: Prof. Dr. Antônio Raimundo Lima Cruz Teixeira

Co-Orientador: Prof. Dr. Rodrigo Gurgel Gonçalves 


\section{TERMO DE APROVAÇÃO}

Rafael Rocha de Andrade

MONITORAMENTO ECOCARDIOGRÁFICO DA MIOCARDIOPATIA AUTOIMUNE DE AVES SINGÊNICAS INFECTADAS EXPERIMENTALMENTE COM TRYPANOSOMA CRUZIE SUBMETIDAS AO TRANSPLANTE DE MEDULA ÓSSEA

Tese apresentada ao programa de Pós-Graduação em Ciências Médicas da Faculdade de Medicina da Universidade de Brasília - UnB, como requisito parcial à obtenção do grau de Doutor.

Orientador:

Prof. Dr. Antônio Raimundo Lima Cruz Teixeira - FM - UnB

Examinadores:

Prof. Dr. Francisco Ernesto Moreno Bernal - FAV - UnB

Profa. Dra. Gláucia Bueno Pereira Neto - FAV - UnB

Profa. Dra. Simone Perecmanis - FAV - UnB

Prof. Dr. Cléver Gomes Cardoso - ICB - UFG

Suplente:

Prof. Dr. João Batista de Sousa - FM - UnB 


\section{DEDICATÓRIA}

Dedico este trabalho a todos os cientistas, que assim como eu, dedicam boa parte do tempo de sua vida a aventurar-se no escuro, frente ao desconhecido. O conhecimento que trazemos, apesar de muitas vezes nos parecer insignificante, possui o incrível poder de beneficiar a humanidade. 


\section{AGRADECIMENTOS}

Agradeço a Deus pela vida, pela saúde, pela família e por todas as oportunidades que consegui aproveitar durante minha existência. Pela benção de ter nascido e vivido ao lado das pessoas que amo, sempre na companhia de pessoas exemplares.

Agradeço à minha esposa, querida companheira, parceira de vida, que desde o dia 21 de Junho de 1997, ainda aos 16 anos de idade, vive ao meu lado com muita paciência e alegria. Minha querida caliandra, flor mais bela e doce do cerrado, EU TE AMO. Obrigado pelas aventuras, pelos momentos felizes e pelo seu sorriso durante todos esses anos de união.

Agradeço também aos dois diamantes que Deus me concedeu para lapidar; alegria eterna do meu coração: meus filhos, Lucas e Diogo. Vocês são o meu maior incentivo para continuar a estudar, a trabalhar, a viver. Vocês me ensinam todos os dias o valor do amor verdadeiro, puro, e sem limites.

Aos meus pais, Miriam e Gabriel, sempre amáveis, carinhosos, e professores da vida. Se hoje tenho a oportunidade de me tornar Doutor, foi graças ao cuidado, ensinamento e educação que tive desde o dia do meu nascimento. Pai e Mãe: obrigado, vocês são maravilhosos.

Agradeço aos meus irmãos Gustavo e Patrícia por compartilharem comigo todas as experiências familiares e da vida, pela amizade que construímos e que levaremos pela eternidade.

Ao meu mestre, professor e amigo, Antônio Teixeira, por me trazer para a Universidade de Brasília, por ser meu mentor e orientador, e por me ensinar que a ciência sempre se inicia de uma curiosidade frente ao desconhecido.

Ao meu Co-Orientador e amigo, Prof. Dr. Rodrigo Gurgel, por sua sempre pronta disposição e por seus ensinamentos; profissional, alegre e com vital participação na construção e sucesso deste trabalho.

Agradeço a amizade e a ajuda de colegas da ciência, amigos de bancada e participantes na realização desse extenso estudo - cientistas que assim como eu, possuem não apenas a curiosidade em desvendar mistérios, mas também a coragem para levar os questionamentos adiante. Estas pessoas simples, que com passos de formiguinha, procuram desvendar a complexa e intrigante patogênese da doença de Chagas. São eles: Adriano Rios, Alessandro Sousa, Ana Luisa, Ana de 
Cássia, Carlos Fernando, Ciro Cordeiro, Cléver Gomes, Erick Muller, Francisco Bernal, Glorinha, Guilherme, Luciana Hangstrom, Maria Carolina, Mariana Hecht, Nadjar Nitz, Perla Araújo, Rozeneide Alves, Tamires Vital e Willie Oliveira.

Agradeço o apoio do Hospital Veterinário de Pequenos Animais da Universidade de Brasília. Em especial à Profa. Gláucia Bueno e ao Prof. Jair Costa pelo apoio técnico e mensuração dos exames de ecocardiografia das aves.

Agradeço também aos meus amigos; pessoas que tive a honra de conhecer durante minha vida. Obrigado avocês que fizeram parte de minha história, do meu crescimento, e que também foram importantes na minha formação como pessoa. Muito obrigado meus queridos amigos, por compatilharem sua existência comigo, pelos momentos, pela companhia e pela amizade. Vocês são especiais, e, mesmo sem saberem, também ajudaram na construção deste trabalho. Obrigado:

Gustavo Andrade, Patrícia Andrade, Matheus Geraldo, Gabriel Henrique, Mateus Alcântara, Pablo Prazeres, Marcelo Miller, Alan Ribeiro, Álvaro Henrique, Ricardo Vazquez, Bruno Dallago, Frederico Rosalino, Felipe Augusto, José Waldo, Franklin Martins, Bruno Chaves, Tamara Chaves, Luísa Zandonadi, Renata Zandonadi, Paulo Zandonadi, Aline Ramos, Felipe Oliveira, Gabriela Mariângela, Bruno Dallago, Ricardo Almeida, Antônio Carlos Bentes, Felipe Bueno, Dindinha, Vovó leda, Vovô Zé (José Geraldo), Frida Kobbe e Leví Fiuza. 


\section{EPÍGRAFE}

"Na natureza não sobrevive a espécie mais forte, mas a que melhor se adapta a mudança"

Charles Darwin 


\section{REFERÊNCIA BIBLIOGRÁFICA E CATALOGAÇÃO}

RAFAEL, R. A. Monitoramento Ecocardiográfico da Miocardipatia Autoimune de Aves Singênicas Infectadas Experimentalmente com Trypanosoma Cruzi e Submetidas ao Transplante de Medula Óssea. Brasília: Faculdade de Medicina, Universidade de Brasília, 2016, 105p. Tese de Doutorado.

Documento formal, autorizando a reprodução desta tese de doutorado para empréstimo ou comercialização, exclusivamente para fins acadêmicos. $\mathrm{O}$ autor e seus orientadores reservam para sí os direitos autorais para publicação.

FICHA CATALOGRÁFICA

Andrade, Rafael Rocha. Monitoramento

Ecocardiográfico da Miocardipatia Autoimune de Aves Singênicas Infectadas Experimentalmente com Trypanosoma Cruzi e Submetidas ao Transplante de Medula Óssea / Brasília: Faculdade de Medicina da Universidade de Brasília, 2016. 105p. Tese (Doutorado em Ciências Médicas) - Faculdade de Medicina da Universidade de Brasília, 2016.

1. Trypanosoma cruzi. 2. Autoimunidade. 3. Ecocardiografia. 4. Doença de Chagas. 7. kDNA. 6. Insuficiência cardíaca. I. Teixeira, A.R.L.C. II. Título. 


\section{RESUMO}

A doença de Chagas subsequente à infecção pelo Trypanosoma cruzi ( $T$. cruzi) é endêmica na América do Sul. O tratamento disponível para a doença clinicamente manifesta é insatisfatório. Neste estudo foram conduzidos experimentos independentes em grupos formados por cinco aves nascidas de ovos inoculados ou não com T. cruzi. A integração de minicírculos de kDNA de T. cruzi no genoma das aves singênicas e a herança do kDNA integrado nas progênies foram anteriormente descritas, e a correlação das alterações genômicas com a doença autoimune do coração foi demonstrada. O presente estudo documenta a cardiomiopatia autoimune de origem genética nas aves kDNA+ a partir de exames de ecocardiograma e aponta a evolução desta patologia nas aves após receberem o transplante de medula óssea. As aves com o genoma modificado pela presença de mutações de kDNA (kDNA+), tiveram a medula óssea destruída com drogas, e receberam, dois dias após, transplante de medula óssea de ave controle (kDNA-) da mesma linhagem. Os resultados demonstram que as aves que tiveram seu genoma modificado pela integração das mutações de kDNA apresentaram a miocardiopatia inflamatória de natureza autoimune. Por outro lado, as aves inicialmente sadias que receberam medula óssea proveniente de aves kDNA+ (grupo de indução da patologia), apresentou substancial decréscimo da fração de ejeção e também na fração de encurtamento. No grupo das aves kDNA+ que receberam medula óssea de animais kDNA- (grupo inibição da patologia) não houve melhora significativa dos principais parâmetros de função miocárdica (fração de ejeção, fração de encurtamento e diâmetro interno do ventrículo esquerdo em sístole) logo nos 3 primeiros meses. Porém, houve uma tendência de melhora da função miocárdica na análise aos 10 meses pós-transplante, indicando uma recuperação de parâmetros da função miocárdica das aves deste grupo tratado com medula óssea sadia. Outros estudos de monitoramento cardíaco mais prolongados são necessários, e devem ser realizados para esclarecer o prognóstico das aves após o tratamento com transplante de medula óssea.

Palavras-Chave: Trypanosoma cruzi; autoimunidade; ecocardiografia; doença de Chagas; kDNA; insuficiência cardíaca. 


\begin{abstract}
Chagas disease caused by Trypanosoma cruzi infection is endemic in South America. The treatment available for the clinically manifested disease is considered unsatisfactory. In this study, we carried out groups of five chickens hatched from the T. cruzi inoculated eggs. The integration of the kDNA minicircle sequences in the chicken genome and their inheritance by progeny was documented and the role played by these genome alterations in the disease pathogenesis was demonstrated. The present study showed the autoimmune cardyopathy in chickens with the T. cruzi $(\mathrm{kDNA}+)$ mutations, which were monitored by the echocardiogram. The chickens with the genome altered by the kDNA mutations $(\mathrm{kDNA}+)$ had the bone marrow destroyed with antimetabolic and cytostatic. The transplantation of chicken control bone marrow, without kDNA mutations (kDNA-), was carried out two days thereafter. The results translated the changes of the cardiophathy after bone-marrow transplantation. It was shown that the control healthy chickens (kDNA-) that received bone-marrow from kDNA+ mutated sick chickens (induction of pathology group), showed significant decrease of shortening and ejection fraction. In the group of kDNA+ chickens that received bone-marrow from healthy (kDNA-) chickens (inhibition of pathology group), there where a significant decrease of the heart function parameters, such as reduction of shortening and ejection fraction of the left ventricle during three months after transplantation. However, it was noticed a sustainable improvement of these heart function parameters (shortening fraction, ejection fraction and internal diameter of left ventricle) in the following ten monts after bone-marrow transplantation. This finding suggest a recovery of the heart function in the kDNA+ chickens that had the bone- marrrow destroyed with drugs and that received healthy (kDNA-) bone-marrow transplantation.Further long run studies of cardiac function monitoring are required to determine the prognosis of the sick kDNA+ chickens after the healthy bone-marrow transplantation.
\end{abstract}

Key words: Trypanosoma cruzi; autoimmunity; echocardiography; Chagas disease; kDNA; cardiac insufficiency. 


\section{LISTA DE FIGURAS}

Figura 1. Modificação do genoma de aves singênicas pela integração de sequências de minicírculos de Trypanosoma cruzi

Figura 2. Aspectos clínicos da ave adulta infectada experimentalmente com T. cruzi ainda em estágio embrionário.

Figura 3. Ave sob anestesia previamente ao procedimento de enxerto de fragmento de coração de pinto de um dia de vida.

Figura 4. Reação autoimune durante a rejeição de enxerto de coração .56

Figura 5. Patologia macro e microscópicaresultante das modificações do genoma de aves singênicas pelas mutações de sequências de kDNA de Trypanosoma cruzi. 58

Figura 6. Inoculação dos ovos embrionados e formação dos grupos Experimentais 68

Figura 7. Tratamento para supressão e transplante da medula óssea em aves Gallus gallus singênicas 76

Figura 8. Visualização do coração da ave em decúbito lateral direito e posicionamento de probe na janela paraesternal da ave. 79

Figura 9. Filme radiográfico resultado de hibridização com sonda radioativa de kDNA de amostras de DNA de aves controle e amostras de DNA de aves oriundas de ovos inoculados com T. cruzi. 82

Figura 10. Gráficos em Box-plot demonstrando os valores das variáveis ecocardiográficas Fração de Ejeção do ventrículo esquerdo (EF) e Fração de Encurtamento (FS) dos 4 grupos de aves em três momentos distintos 
Figura 11. Gráficos em Box-plot demonstrando os valores das variáveis ecocardiográficas dos 4 grupos de aves em três momentos distintos..... 86 


\section{LISTA DE TABELAS}

Tabela1. Sequência dos primers S35 e S36

Tabela 2. Estatísticas resultantes das comparações entre os quatro grupos experimentais de acordo com as oito variáveis ecocardiográficas analisadas pelo teste de Kruskal-Wallis. 84

Tabela 3. Estatísticas resultantes das comparações dos parâmetros ecocardiográficos comparando as cinco aves de um mesmo grupo experimental, analisadas pelo teste de Wilxocon. 87 


\section{LISTA DE ABREVIATURAS E SIGLAS}

${ }^{\circ} \mathrm{C}$ : $\quad$ Graus Celsius

dATP: Desoxiadenosina Trifosfato

DIVEd: Diâmetro interno do Ventrículo Esquerdo em diástole

DIVEs: Diâmetro Interno do Ventrículo Esquerdo em sístole

DNA: Ácido desoxiribonucleico

EF: Fração de Ejeção do ventrículo esquerdo

ELISA: Ensaio de Imunoabsorção Enzimática

FS: Fração de Encurtamento

HE: Hemoaglutinação

I.V: $\quad$ Via endovenoso

IFI: Imunofluorescência Indireta

IFN-y: Interferon gamma

IgG: Imunoglobulina $G$

IgM: Imunoglobulina $\mathrm{M}$

IL-10: Interleucina 10

$\mathrm{kb}$ : Kilobases ou mil pares de bases nitrogenadas

kDNA: DNA do cinetoplasto

$\mathrm{Kg}$ : Quilograma

LMPDC: Laboratório Multidisciplinar em Pesquisa de Doença de Chagas

Mm: Milímetro

NAOH: Hidróxido de Sódio

nDNA: DNA de origem nuclear

$\mathrm{Pb}: \quad$ Pares de bases nitrogenadas

PCR: Reação em Cadeia da Polimerase

PEG: Polietileno Glicol

PIB: Produto Interno Bruto

PLVEd: Espessura da Parede Livre do Ventrículo Esquerdo em diástole

PLVEs: Espessura da Parede Livre do Ventrículo Esquerdo em sístole

RNA: Ácido ribonucleico 
rRNA: Ácido ribonucleico ribossomal

SDS: Dodecil Sulfato de Sódio

SIVd: Espessura do septo interventricular em diástole

SIVs: Espessura do septo interventricular em sístole

SSPE: Tampão Salino Fosfato de Sódio - EDTA

T. cruzi: Trypanosoma cruzi

TNF-a: Fator de Necrose Tumoral alfa

UMR: Unidade mínima de rejeição

WHO: Organização Mundial de Saúde

$\mu \mathrm{g}$ : Micrograma

$\mu \mathrm{l}$ : Microlitro 
1.1 Evolução dos seres vivos e transferência gênica horizontal

1.2 Nota sobre a descoberta do Trypanosoma cruzi ....................................22

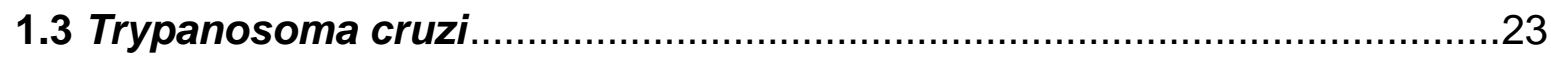

1.4 O DNA mitocondrial do Trypanosoma cruzi (kDNA)................................24

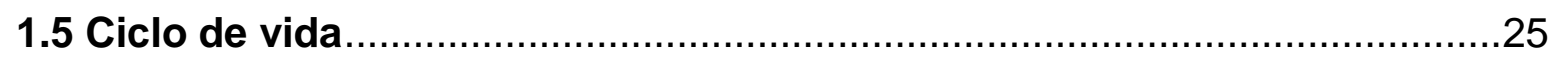

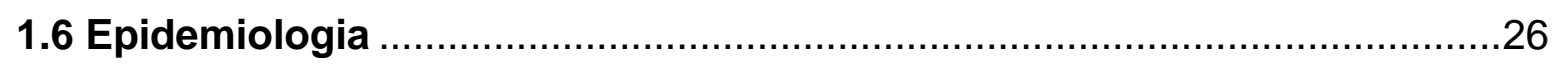

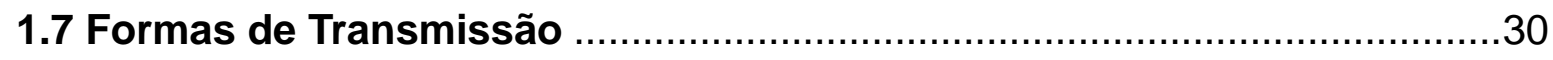

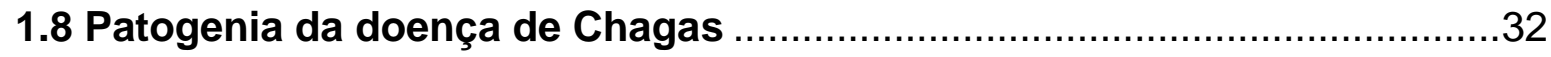

1.8.1 Teoria local ou focal ................................................................................. 33

1.8.2 Teoria neurogênica ou parassimpaticopriva............................................ 34

1.8.3 Teoria da autoimunidade ........................................................................ 34

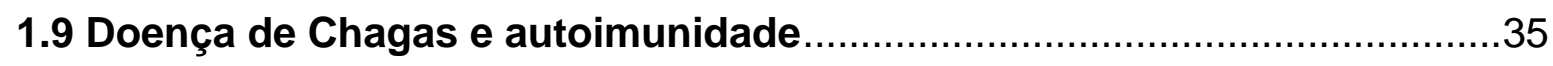

1.10 Sinais Clínicos da Doença de Chagas .......................................................38

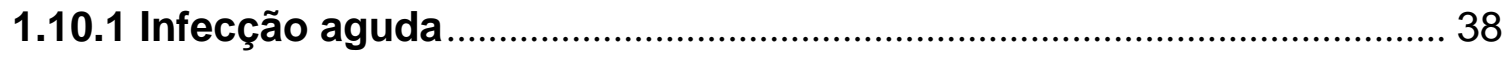

1.10.2 Fase indeterminada da doença de Chagas .............................................. 39

1.10 .3 Infecção crônica .................................................................................... 40

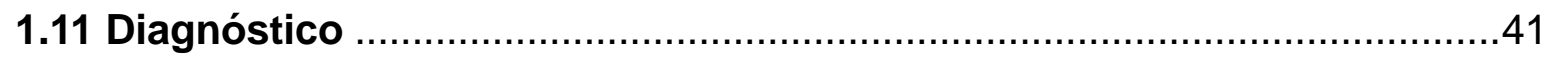

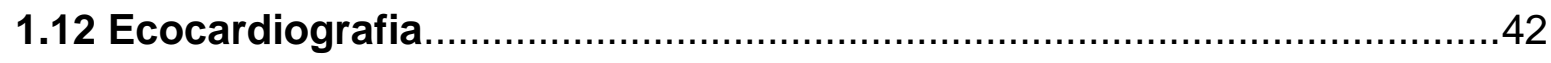

1.13 Tratamento

1.14 Modificação dos genomas de aves pela integração de sequências de minicírculos de kDNA de Trypanosoma cruzi ................................................

1.15 Aves Gallus gallus como modelo experimental em doença de Chagas .50 
1.15.1 Sinais clínicos desenvolvidos pelas aves mutadas

1.16 Enxerto de tecido cardíaco

1.17 Patologia nas aves e proposta de tratamento com transplante de medula óssea .59

2 Justificativa 61

3 Objetivo Geral 62

3.1 Objetivos específicos. .62

4 Material e métodos 63

4.1 Modelo Animal .63

4.2 Reprodução das aves e composição de grupos experimentais .64

4.3 Inoculação de Trypanosoma cruzi na câmara de ar de ovos embrionados .66

4.4 Grupos experimentais .66

4.5 Diagnóstico Molecular. 69

4.5.1 Extração de DNA das Aves 69

4.5.2 Extração de kDNA de Trypanosoma cruzi ……………………………..... 70

4.5.3 Quantificação e teste de qualidade do DNA …………………………….... 70

4.5.4 Reação em Cadeia da Polimerase (PCR) ………………………………... 71

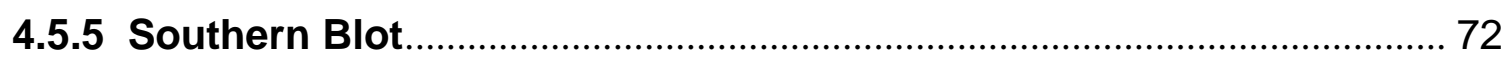

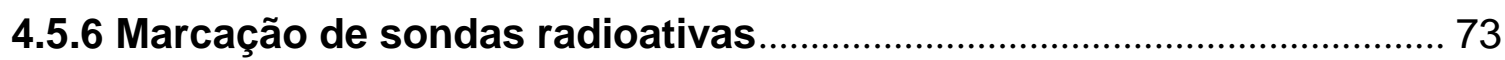

4.5.7 Purificação de sondas radioativas …………………………………......... 73

4.5.8 Hibridização com sondas radioativas ........................................................ 73

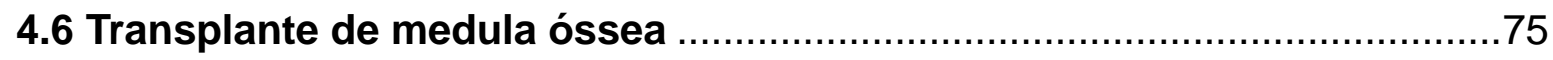

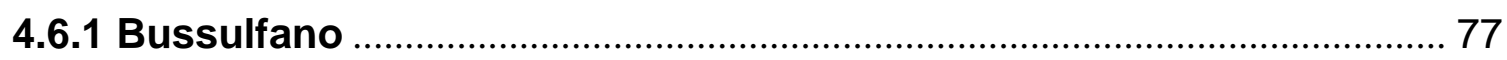

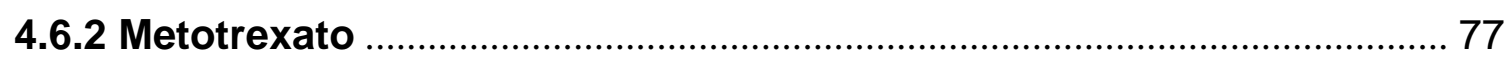




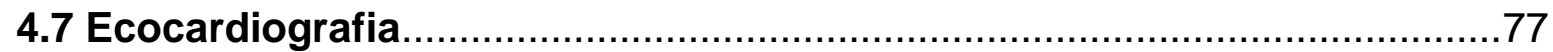

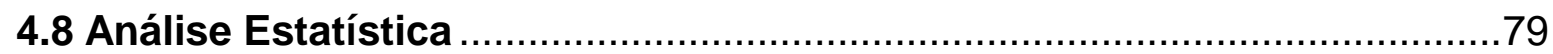

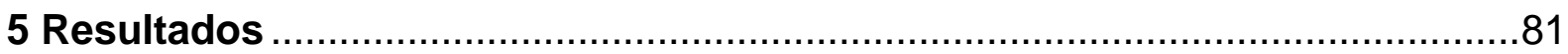

5.1 Modificação dos genomas das aves pela integração de sequências de

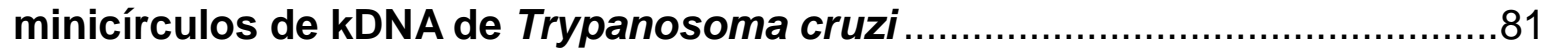

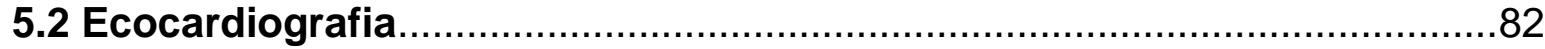

6 Discussão

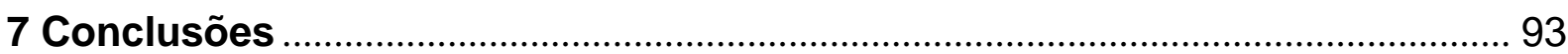

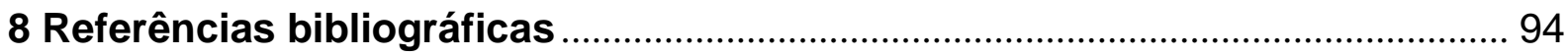

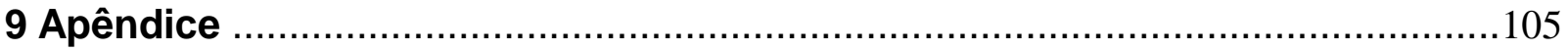




\section{INTRODUÇÃO}

\subsection{Evolução dos seres vivos e transferência gênica horizontal}

A evolução gênica corresponde ao aumento da complexidade dos genomas, da crescente variabilidade genética das populações e, ocasionalmente, permite o surgimento de novas espécies ao longo de milhares de anos (Via, 2009; Futuyma, 2013). Desde o surgimento dos primeiros seres unicelulares e da vida na Terra, há aproximadamente 3,8 bilhões de anos, os seres vivos estão sujeitos a modificações significativas de seus genomas.

O desenvolvimento das tecnologias de sequenciamento genético tem permitido a investigação da origem de genes exóticos ao organismo em estudo e está sendo amplamente utilizada para identificar a evolução do genoma humano, dos animais e das plantas (Keeling e Palmer, 2008). Este método permite aos pesquisadores decifrar a árvore genealógica e a evolução gênica dos organismos. Muitos trabalhos têm sido descritos utilizando esta técnica e relatam que a troca de material genético entre espécies diferentes é um evento muito comum em todos os filos, sendo mais frequente entre as bactérias, mas que também ocorre com organismos eucariontes (Dunn e Ryan, 2015).

A análise das sequências dos genomas dos organismos demonstra que as modificações no DNA resultantes de transferências gênicas (vertical ou horizontal), duplicações, perdas de genes e falhas no mecanismo de reparo são as principais forças relacionadas com a evolução genômica dos seres vivos (Kurland et al., 2003). Ainda que seja difícil a detecção de recombinações gênicas de um organismo, sabese que alterações genotípicas e fenotípicas podem ser benéficas, e favorecer funções vitais para a sobrevivência em maior escala (Dunn e Ryan, 2015).

A recombinação do DNA cria novos genes, os mistura com os demais já existentes e origina diversidade genética dos organismos em uma população. Dentre as formas de recombinação gênica conhecidas cita-se a aquisição de material genético por transferência horizontal (Keeling e Palmer, 2008). Transferência gênica horizontal é caracterizada pela troca de material genético de uma célula a outra que não é sua descendente, inclusive entre indivíduos de filos distantes (Brown, 2003; Goldenfeld e Woese, 2007). Este evento é considerado comum na natureza 
(Andersson, 2009). A ocorrência de transferência gênica horizontal permite ao organismo receptor a incorporação do fragmento de DNA exógeno ao seu. O enxerto do DNA exógeno em elementos transponíveis denominados transposons do genoma receptor possibilita a formação de pseudogenes e de novos genes. Após a ocorrência da transferência horizontal, novas sequências de elementos de transposição não são silenciadas pelo genoma do hospedeiro e permitem a expansão do seu número de cópias (Teixeira et al., 2011b).

Estudos genéticos das populações demonstram que a transferência gênica horizontal é um dos fatores que modificam o DNA ao longo da evolução dos seres vivos. Entretanto, nem todas as alterações gênicas resultam em alterações fenotípicas, já que a grande maioria das regiões do genoma é silenciosa ou expressa mínima atividade funcional (Simonti e Capra, 2015). Esse fato dificulta a identificação de alterações genotípicas que resultam em alterações fenotípicas vantajosas para a espécie em questão (Dunn e Ryan, 2015).

A maior parte dos estudos envolvendo a transferência horizontal de genes focam seus esforços em organismos procariotos por terem o genoma menor e, portanto, mais fáceis de serem estudados. Contudo, com os avanços nos estudos dos genomas, os cientistas começam a relatar este fenômeno em organismos eucariotos. O desenvolvimento das tecnologias de sequenciamento de genes na atualidade permite a investigação da origem de genes exóticos ao organismo em estudo e está sendo amplamente utilizada para identificar a evolução do genoma humano, dos animais e das plantas (Keeling e Palmer, 2008). Adicionalmente, tais sequências de DNA oriundas de organismos distantes no filo não são extintas, uma vez que serão perpetuadas também por transmissão vertical, e permitem serem identificadas (Carvalho, 2013; Teixeira et al., 2006b).

\subsection{Nota sobre a descoberta do Trypanosoma cruzi}

O parasito T. cruzi foi descrito por Carlos Chagas em 1909. Nesse ano, o cientista brasileiro observou a presença de microrganismos flagelados no sangue de uma criança febril de dois anos de idade. Após algumas semanas, quando essa criança já não apresentava mais sintomas,ele percebeu que já não era mais possível 
encontrar esses parasitas flagelados no sangue da paciente e, a partir daí, começou seus estudos para entender melhor essa doença, denominando o parasita flagelado de T. cruzi, em homenagem a Oswaldo Cruz, seu mentor. Durante sua pesquisa, Carlos Chagas descreveu de forma brilhante o patógeno, o vetor e as características clínicas dessa nova doença (Chagas, 1909; Tanowitz et al., 2009). Após muitos anos, já em 1961, essa mesma criança que foi diagnosticada com os parasitas em 1909, foi localizada e re-examinada por pesquisadores da Universidade Federal de Minas Gerais e do Instituto Nacional de Endemias Rurais de Belo Horizonte. Seu nome era Berenice e vivia uma vida normal, sem diferenças clínicas em relação às pessoas sadias. Durante os exames, foi observada novamente a presença dos parasitas circulando no sangue da paciente; desta vez, o parasito foi isolado, cultivado em laboratório, e desde então foi utilizado em diversas pesquisas (Salgado, 1980). Berenice morreu de causa desconhecida em 1973, livre de qualquer sintoma característico da doença de Chagas.

Mais de 100 anos após a descoberta da moléstia e do parasito, a doença de Chagas permanece como grande desafio à saúde pública, em especial, de países da América Latina. Atualmente, com a globalização e imigração mais acentuada, a doença de Chagas se espalhou pelo mundo e se tornou prevalente também nos países não endêmicos (Schmunis et al., 2007).

\subsection{Trypanosoma cruzi}

A doença de Chagas ou tripanossomíase americana é uma zoonose resultante da infecção crônica pelo protozoário flagelado Trypanosoma cruzi (T. cruzi). Análises filogenéticas realizadas com o gene 16S rRNA sugere que o T. cruzi surgiu há 100 milhões de anos, em um supercontinente formado pela união da América do Sul, Antártica e Austrália (Steverding, 2014). Naquela época, os primeiros hospedeiros do parasito foram mamíferos das ordens Didelphimorphia (gambás e outros marsupiais neotropicais) e Cingulata (tatus), os quais podem ser considerados como os hospedeiros mais antigos do T. cruzi (Roque e Jansen, 2014).

Trypanosoma cruzi é um parasito unicelular, intracelular obrigatório do filo Euglenozoa, família Trypanosomatidae e classe Kinetoplastida (Martin e Borst, 2003). Sua única mitocôndria possui o cinetoplasto, uma estrutura contendo DNA 
extra nuclear (Souza et al., 2010). Este protozoário é heteroxênico, uma vez que necessita passar por dois hospedeiros diferentes para completar seu ciclo de vida, um hospedeiro invertebrado, o triatomíneo, e outro vertebrado. Os tripanossomatídeos pertencentes aos gêneros Leishmania e Trypanosoma têm grande importância para a medicina humana e veterinária (Teixeira et al., 2006). OT. cruzi possui sete linhagens geneticamente distintas ou unidades discretas de tipificação (DTUs), Tcl-TcVI (Zingales et al., 2012) e TcBat (Lima et al. 2015). A linhagem Tcl é frequentemente isolada de mamíferos silvestres nos diversos biomas; o Tcll já foi encontrado em uma grande variedade de espécies de mamíferos domésticos e silvestres, sendo o principal agente da doença de Chagas na região Sul e Central da América do Sul. As linhagens TcIll e TcIV são menos frequentes, porém possuem igualmente ampla distribuição, enquanto que $T c V$ e $T c V I$ são comuns em isolados de humanos, ou de triatomíneos que habitam ambiente domiciliar (Lima et al., 2014) e a linhagem TcBat é associada a morcegos (Lima et al., 2015).

\subsection{O DNA mitocondrial do Trypanosoma cruzi (kDNA)}

O protozoário Trypanosoma cruzi tem como principal característica conter uma única mitocôndria simbiótica, contendo o cinetoplasto, estrutura que alberga o DNA extranuclear do parasito, também denominado kDNA (Fidalgo e Gille, 2011; Teixeira et al., 2011b). O kDNA corresponde a aproximadamente $25 \%$ de todo o material genético do parasito e está organizado em estruturas circulares de DNA concatenado, denominados maxicírculos e minicírculos (Guimaro et al., 2014). Sua decatenação pode ser feita pela clivagem com enzima topoisomerase II que lineariza os maxicírculos e minicírculos (Liu et al., 2005).

Em cada cinetoplasto, os maxicírculos, com cerca 40kb, possuem aproximadamente 40 a 50 cópias. Os genes que codificam as proteínas mitocondriais localizam-se nas sequências dos maxicírculos (Klingbeil et al., 2004).

Já os minicírculos, com tamanho médio de $1.4 \mathrm{~kb}$, são encontrados no cinetoplasto em maior abundância, cerca de 15000 cópias. Cada minicírculo tem estrutura circular com quatro regiões conservadas (120-160 pb) intercaladas por quatro regiões variáveis (280-320 pb). As quatro regiões conservadas possuem sequências ricas em citosina e adenina, que são funcionalmente associadas ao sítio 
de origem de replicação, transcrição, recombinação e de mediação da transferência de kDNA ao genoma do hospedeiro. A amplificação por PCR com primers específicos, denominados S35 e S36, da região variável dos minicírculos, geram fragmentos com cerca de $330 \mathrm{pb}$, enquanto que na região conservada geram fragmentos de 120 pb (Shapiro e Englund, 1995; Junqueira et al., 2005; Teixeira et al., 2011b).

A possibilidade de trocas genéticas entre T. cruzi e o hospedeiro foi sugerida em trabalhos que utilizaram técnicas de hibridização in situ, que possibilitou detectar a presença de minicírculos de kDNA do protozoário no genoma de células dos hospedeiros (Teixeira et al., 1991; Teixeira et al., 1994).

As técnicas que permitem a identificação de transferência gênica do parasito para o hospedeiro foram aprimoradas nos últimos anos. Os amplicons, ou produtos amplificados pela PCR, são identificados pela hibridização com sonda radiomarcada de kDNA. Os produtos identificados são submetidos a clonagem e sequenciamento, permitindo a confirmação de sequências de minicírculos de kDNA do T. cruzi em diversos sítios do genoma humano, de aves e de outros mamíferos (SimõesBarbosa, 1999; Teixeira et al., 2006; Hecht et al., 2010; Teixeira et al., 2011a; Teixeira et al., 2011b; Guimaro, et al., 2014).

\subsection{Ciclo de vida}

O protozoário Trypanosoma cruzi pode infectar cerca de 150 espécies de triatomíneos (Galvão e Gurgel-Gonçalves, 2014) e mais de 250 espécies de mamíferos (Hecht et al., 2010; Jansen et al., 2015). As aves são refratárias a infecção (Dias, 1944; Nery-Guimarães e Lage, 1972; Kierszenbaum et al., 1976).

O ciclo de vida do $T$. cruzi inicia-se com as formas tripomastigotas que 0 triatomíneo adquire sugando do hospedeiro infectado. As tripomastigotas ingeridas diferenciam-se em epimastigotas e multiplicam-se no intestino médio do inseto. Já no intestino posterior, ocorre a transformação em tripomastigotas metacíclicos, formas infectantes que são eliminadas junto com as fezes do inseto durante a alimentação e penetram pelas mucosas do hospedeiro ou através do orifício da picada do inseto. Após a entrada desses tripomastigotas metacíclicos no corpo do hospedeiro, estes são fagocitados por células do sistema monocítico-fagocitário, 
principalmente os macrófagos e monócitos, e são rapidamente destruídos. Entretanto, alguns tripomastigotas conseguem internalizar em células não fagocíticas, conseguindo sobreviver ao ataque do sistema imune do hospedeiro. Uma vez dentro dessas células, os tripomastigotas são recrutados pela célula hospedeira para dentro do vacúolo do lisossomo. Os parasitos permanecem no interior do lisossomo por algumas horas quando o vacúolo se rompe, liberando-os no citoplasma da célula hospedeira. No citoplasma, os tripomastigotas se diferenciam em amastigota, que é a forma replicável, sem flagelo e mais arredondada. A forma amastigota começa então a se replicar no citoplasma da célula do hospedeiro. Posteriormente, por mecanismos ainda não esclarecidos, a replicação cessa, ocorrendo a diferenciação das formas amastigotas para a forma tripomastigota, que culmina por romper a membrana da célula do hospedeiro e por liberar os parasitos no sangue. No sangue os parasitos se disseminam, infectando outras células mais distantes, ou podem ser sugados pelo inseto triatomíneo recomeçando o ciclo (Burleigh, 2004).

Dentro da célula do hospedeiro, T. cruzi se reproduz principalmente por fissão binária, entretanto, sabe-se também que podem ocorrer eventos de reprodução sexuada, fato que possibilita a mistura de material genético entre esses tripanossomatídeos, devido a ocorrência de infecções mistas por mais de uma linhagem deste protozoáriono em um mesmo hospedeiro (Gaunt et al., 2003).

A variabilidade genética das linhagens do parasito está associada a mudanças de sua biologia, tais como na preferência entre hospedeiros, virulência, tropismo de células parasitadas entre outras características, fato que dificulta os estudos da patogenia da doença (Dutra et al., 2014). Com grande capacidade adaptativa, verifica-se que T. cruzi é capaz de infectar e multiplicar-se numa grande variedade de células nos tecidos de hospedeiros vertebrados (Burleigh, 2004; Teixeira et al., 2011b).

\subsection{Epidemiologia}

Há evidências de que ciclos enzoóticos de T. cruzi ocorrem há milhões de anos (Coura, 2007). Acredita-se que no início as infecções enzoóticas teriam sido adquiridas por via oral quando mamíferos ingeriam triatomíneos infectados por $T$. 
cruzi. A medida que muitos mamíferos se tornaram infectados, a transmissão por insetos hematófagos passou a ter maior importância na propagação de $T$. cruzi (Diotaiuti, 2009). A transmissão do T. cruzi ao homem teria sido iniciada de forma acidental, com a chegada dos primeiros habitantes ao continente americano, cujos primeiros fósseis encontrados datam de aproximadamente 50 mil anos atrás (Bahn, 1993). Aufderheide e colaboradores (2003) relatam a descoberta de vestígios de DNA de T. cruzi em restos mortais de múmias de 9.000 anos na região ao norte do Chile e sul do Peru. Nesse trabalho, os autores sugerem que o ciclo silvestrede $T$. cruzi nos mamíferos já era bem estabelecido desde antes do aparecimento dos primeiros habitantes humanos na América Latina e começou a ser transmitido para o homem após a sua entrada no ambiente silvestre.

A adaptação dos triatomíneos na convivência com o homem no peridomicílio é um fator importante na transmissão de T. cruzi a humanos (Coura, 2007). No Brasil, existem indícios que a doença de Chagas já ocorria em humanos entre os séculos XVI a XVIII. Naquela época, ocorria um processo de imigração de brasileiros e portugueses que colonizavam o interior do país, avançando para regiões endêmicas da doença. Os relatos da época demonstram a ocorrência de pessoas com sintomas semelhantes aos da doença de Chagas e que eram popularmente comentados como mal do bicho ou mal do engasgo (Dias e Schofield, 2009).

As infecções pelo T. cruzi ocorrem do sul da Argentina ao sul dos Estados Unidos, mas a doença tem se espalhado globalmente em virtude da imigração de pessoas de áreas endêmicas para outros países. A doença de Chagas afeta pessoas que vivem em área de risco nas regiões endêmicas (Coura e Dias, 2009; Teixeira et al., 2011a; WHO, 2015). Há algumas décadas a doença de Chagas era uma enfermidade restrita, prevalente de áreas rurais dos países da América Latina e Estados Unidos, mas devido a imigração populacional, ela se espalhou para os grandes centros urbanos e para os países não endêmicos, que eram livres da transmissão vetorial (Biolo et al., 2010).

No Brasil, a estimativa mais atual indica que cerca de 4,6 milhões de pessoas estão infectadas por T. cruzi e aproximadamente 12.500 óbitos são registrados anualmente (Tanowitz et al., 2009; Lima et al., 2012; Martins-Melo et al., 2014).

Estima-se que aproximadamente 300.000 pessoas estejam infectadas nos Estados Unidos, a maior parte dessas pessoas são imigrantes provenientes de 
áreas endêmicas da América Latina (Bern, 2011, Biolo et al., 2010; Lima et al., 2012). Entretanto, insetos vetores e animais infectados com $T$. cruzi já foram identificados em várias regiões do sul dos Estados Unidos. Bern e colaboradores (2007) relataram 500 amostras de doação de sangue positivas no ano de 2006 e atentam para o perigo da transmissão do $T$. cruzi a partir da transfusão de sangue nos Estados Unidos.

Na Europa, a estimativa é que 14.000 a 181.000 pessoas estejam infectadas por T. cruzi, a maior parte residentes na Espanha, Itália e Reino Unido (Gobbi et al., 2014). Em países não endêmicos a mais importante via de transmissão da doença de Chagas é a partir da transfusão de sangue, já que nesses países ainda não foram implantados programas para detectar $T$. cruzi em bancos de sangue (Dutra et al., 2014). Dados epidemiológicos apontam ainda para 1500 pessoas infectadas pelo T. cruzi na Austrália e 3000 no Japão (Miranda et al., 2015).

Dados epidemiológicos de pessoas infectadas por T. cruzi são conflitantes, mas demonstram que desde 1990 houve considerável decréscimo no número de pessoas infectadas. A Organização Mundial da Saúde (WHO), em seu relatório de 2002, divulgou que havia 18 milhões de pessoas infectadas com o T. cruzi. Já em dois relatórios seguintes, em 2007 e em 2015, esse órgão reportou em ambos que existiam aproximadamente de 6 a 7 milhões de pessoas infectadas pelo protozoário (WHO, 2007; 2015). Isso representa uma redução dos casos de mais de $50 \%$ em um curto período de tempo, fato atribuído aos programas de controle dos vetores nas áreas endêmicas (Biolo et al., 2010; Rassi et al., 2010) além de maior controle dos bancos de sangue, onde passou-se a ser obrigatório o teste de sorologia de todos os doadores para esta doença.

O reconhecimento da prevalência de casos de doença de Chagas no Brasil começou em 1975, quando foi iniciado no Brasil o programa de controle de transmissão vetorial do $T$. cruzi. Tal medida compreendia a borrifação de inseticidas nas casas e no peridomicílio de áreas onde ocorria a infestação dos barbeiros, com objetivo de acabar com o ciclo de transmissão vetorial nestas áreas. O programa também contemplava medidas educativas sanitárias e estabeleceu um sistema de vigilância envolvendo os membros das comunidades locais. Esse programa mostrou-se efetivo para eliminação do vetor Triatoma infestans, o mais importante vetor do ciclo doméstico no Brasil. No início do programa, 711 municípios estavam 
infestados pelo T. infestans. Entretanto, após a borrifação de inseticida nos domicílios, a presença desta espécie foi ficando cada vez mais escassa. Cerca de 166.000 insetos foram capturados no programa de controle em 1975 e apenas 6.111 foram capturados em 1999 (Andrade et al., 2011).

Podemos atribuir o sucesso do programa de controle a diminuição da transmissão do principal vetor pela a pulverização de inseticida no ambiente intra e peridomiciliar, mas também pela melhoria na situação socioeconômica do país. A partir da década de 1960 houve um crescente deslocamento da população rural para os centros urbanos, consequência da modernização da agricultura e intenso processo de industrialização. Em 1950, a população rural brasileira correspondia a $63,8 \%$ da população total, enquanto no início da década de 1970 era de $50 \%$ e, atualmente, não é maior do que $20 \%$ do total de habitantes. Houve também uma melhora significativa dos indicadores econômicos e sociais. Devemos considerar que desde 2005 o país ingressou no grupo de países com alto índice de desenvolvimento humano e que o PIB per capita aumentou cerca de quatro vezes nos últimos 40 anos. Esse panorama resultou em progressiva redução de casas rurais de má qualidade em todo o país. Portanto, as ações continuadas de controle e eliminação do principal vetor, aliado a mudanças econômicas e sociais, determinaram que o risco de transmissão vetorial da doença de Chagas no Brasil esteja hoje circunscrito a determinadas áreas (Silveira e Dias, 2011).

Não obstante ao sucesso do programa, a transmissão vetorial continua ocorrendo no Brasil devido a presença de espécies nativas, tais como, o Panstrongylus megistus, Triatoma brasiliensis e o Triatoma pseudomaculata, e que apresentam importante capacidade vetorial (Silveira e Dias, 2011; Abad-Franch et al., 2013; Vinhaes et al., 2014).

A prevalência de infecção humana pelo $T$. cruzi, em baixas faixas etárias, é considerado um indicador de controle da sua transmissão. Desta forma, a diminuição da transmissão de T. cruzi ao homem foi comprovada com a análise de três inquéritos sorológicos realizados com crianças de faixa etária entre 7 a 14 anos. Em 1980, a taxa de soropositividade nesta faixa etária era de 18,5\%, contra os 0,04\% encontrado em 1999, uma redução de 99,8\%. Já em 2007 , os resultados de 105.000 testes sorológicos em amostras de crianças entre 0 a 5 anos de idade, realizados em quase todos os estados brasileiros, com exceção do Rio de Janeiro, 
indicaram positividade em $0,01 \%$ (Ostermayer et al., 2011). Segundo Dias et al. (2008), a doença de Chagas não pode ser erradicada devido a capacidade que o $T$. cruzi teve de se adaptar e se disseminar hospedando uma grande variedade de espécies de mamíferos, nos diversos ecossistemas nas Américas.

\subsection{Formas de Transmissão}

A principal forma de transmissão de $T$. cruzi aos humanos ocorre quando os parasitos existentes nas fezes do triatomíneo entram em contato com as mucosas, ou através de lesões preexistentes, ou resultante da entrada do parasito pelo local da picada do barbeiro. Além dessa, existem outras formas de transmissão da infecção que também são importantes: via congênita ou vertical, transfusão de sangue, transplante de órgãos, ingestão de alimentos contaminados, via sexual e acidentes laboratoriais (Coura, 2007; WHO, 2007; Lima et al., 2012; Ribeiro et al., 2016).

A transmissão de $T$. cruzi do mamífero infectado ao vetor é garantida quando o hospedeiro infectado apresenta formas circulantes do parasito no sangue (tripomastigotas). Já a transmissão do parasito entre duas espécies de mamíferos, pela predação, pode ser garantida mesmo na ausência de formas circulantes do parasito no sangue, visto que formas amastigotas presentes nos tecidos do mamífero predado também podem ser fonte de infecção (Roque e Jansen, 2014).

Nos últimos anos, as formas de transmissão vertical e oral ganharam importância epidemiológica, sendo responsável por vários casos identificados no Brasil. A transmissão por via oral é importante em regiões onde a prevalência de triatomíneos infectados por $T$. cruzi é alta, como no caso da região amazônica (Valente, 1999). Nesta região a manutenção e a disseminação do T. cruzi no ciclo silvestre é facilitada pelo hábito alimentar insetívoro de pequenos mamíferos e marsupiais, ou mesmo pela predação de outros mamíferos infectados (Yaeger, 1971; Shikanai-Yasuda e Carvalho, 2012).

Nos humanos, a transmissão oral é relacionada com microepidemias, em uma região limitada, geralmente entre familiares (Valente, 1999). A infecção pela via oral é geralmente associada com a infecção aguda mais severa da doença de Chagas, onde os sinais clínicos são mais intensos, inclusive com alta taxa de mortalidade 
(Rassi et al., 2010). No Brasil existem relatos de ocorrência de microepidemia da forma aguda da doença de Chagas transmitida por via oral após consumo de açaí (Pará e Amazonas) e também do caldo de cana (Santa Catarina). Em ambos os casos é provável que o inseto infectado tenha sido macerado junto com a polpa durante o preparo desses alimentos (Shikanai-Yasuda e Carvalho, 2012). Uma microepidemia importante ocorreu na Venezuela em 2007, onde 128 pessoas, a grande maioria crianças, foram infectadas após consumo de suco de goiaba em uma escola municipal (Rodriguez-Morales, 2008).

A transmissão congênita do $T$. cruzi em mulheres gestantes na fase crônica da doença ocorre em menos de $2 \%$ dos casos na América Latina. A exceção ocorre na Bolívia e no Paraguai, onde foram encontradas taxas de transmissão congênita de até 5\% (Rassi et al., 2010). A infecção pelo T. cruzi nas mulheres gestantes e no feto pode causar morte fetal, aborto, nascimento prematuro e retardo do crescimento fetal (Teixeira et al., 2011). A passagem do T. cruzi da mãe ao filho se dá por via placentária, produzindo uma placentite aguda. $\mathrm{Na}$ maioria das ocorrências o parasitismo é acentuado. Nos casos de natimortalidade há, no produto da concepção, parasitismo e lesões inflamatórias mais frequentes no sistema nervoso central, coração, fígado, trato gastrointestinal e pele. $O$ óbito na forma congênita deve-se, em geral, a miocardite, a meningoencefalite ou a infecções intercorrentes (Lopes e Chapadeiro, 1997).

Os casos de transmissão congênita no Brasil diminuíram devido ao declínio dos casos de prevalência de infecção por $T$. cruzi entre gestantes. Estudos em série realizados em Bambuí/MG mostram que, em 1950, a prevalência encontrada na região era acima de $30 \%$ das mulheres, baixando para $9 \%$ nos anos 70 e para menos de 1\% em 2006 (Dias e Neto, 2011).

Outra forma importante de transmissão de $T$. cruzi, e a principal nos países não-endêmicos, é por meio da transfusão de sangue infectado com o parasito. Esta forma de transmissão tornou-se rara no Brasil com a normatização da hemoterapia e devido aobrigatoriedade dos serviços de saúde de bancos de sangue a realizarem testes sorológicos em todos os candidatos à doação (Dias, 2006). Segundo Rassi et al. (2010), a probabilidade de uma pessoa se infectar após a transfusão com sangue proveniente de um doador infectado é de menos de $20 \%$; a depender da quantidade 
de parasitos no sangue, a composição do sangue do doador e também da cepa do protozoário.

Em um estudo recente realizado com camundongos, Ribeiro e colaboradores (2016) demonstram que é possível também a transmissão sexual do T. cruzi em condições experimentais. Nesse estudo foram feitos testes parasitológicos, sorológicos e moleculares de 20 camundongos infectados e também em seus parceiros sexuais inicialmente sadios. Os resultados demonstraram que, após o acasalamento com animais infectados, os parceiros sexuais sadios apresentaram testes sorológicos positivos em $60 \%$ dos casos.

A doença de Chagas tornou-se um importante problema médico e social em quase toda a América Latina por todo o século $X X$ e foi combatida nas últimas décadas, alcançando resultados muito satisfatórios em termos de sua transmissão vetorial e transfusional (Dias et al., 2008).

\subsection{Patogenia da doença de Chagas}

O protozoário Trypanosoma cruzi invade as células do corpo de mamíferos e replica em diferentes tipos de células do hospedeiro. Sabe-se que ao invadir fibroblastos, macrófagos e qualquer das células nucleadas do corpo, particularmente do músculo esquelético e do coração, o parasito multiplica-se e preenche o citoplasma da célula hospedeira, rompendo-a.

O parasitismo pode ser identificado frequentemente na fase aguda da doença, mas, na fase crônica, praticamente não há vestígios do T. cruzi. Nos tecidos o parasito é prontamente fagocitado pelas células do sistema fagocítico mononuclear. A migração das células imunes para o local do parasitismo ocorre por quimiotaxia e depende da produção de citocinas e quimiocinas, assim como da regulação da expressão de seus receptores e moléculas de adesão (Gutierrez et al., 2009).

$\mathrm{Na}$ fase aguda da doença ocorre intensa ativação policlonal de linfócitos T e B. Além disso, estudos atuais demonstram que os linfócitos T CD8 são predominantes no tecido cardíaco na fase crônica da doença. Esses linfócitos T CD8+ são conhecidos por sua atividade citolítica e importantes tanto nas respostas imunes contra T. cruzi, com aprodução de citocinas como o IFN-y e IL-10, como para o desenvolvimento da imunopatogênese da doença de Chagas, já que estão 
envolvidos na lesão tissular do tecido cardíaco (Bonney e Engman, 2008; Gutierrez et al., 2009; Teixeira et al., 2011b).

Estudos em modelos experimentais demonstram que a infecção pelo T. cruzi provoca uma reação inflamatória intensa durante a fase aguda com tripomastigotas abundantes no sangue e o aumento da produção de citocinas, como o IFN-y e o TNF-a, que mobilizam células inflamatórias para eliminar o parasito. Já no início da fase indeterminada da doença, ocorre um substancial aumento na produção da citocina IL-10, evento que é associado como importante regulador da reação inflamatória intensa existente durante a fase aguda. Por mecanismos ainda desconhecidos, o início da fase crônica da doença é marcado por perda do controle da resposta imunológica e que culmina com aparecimento de reação inflamatória intensa multifocal e destruição das células no coração ou no sistema digestório (Dutra et al., 2014). A única evidência patológica comum no tecido cardíaco de pacientes na fase crônica da doença é a presença de infiltrado mononuclear multifocal, geralmente sem a presença do parasito, que, em decorrência de uma reação inflamatória persistente, levam a destruição progressiva do tecido cardíaco (Teixeira et al., 2006b).

\subsubsection{Teoria local ou focal}

A teoria local ou focal trabalha com a hipótese de que as lesões no miocárdio são ocasionadas pela presença direta do T. cruzi e/ou seus antígenos no tecido cardíaco. Porém, esta teoria é incapaz de explicar porque os sintomas cardíacos ou digestivos de pacientes com doença de Chagas só aparecerem na doença crônica, 30-40 anos após a infecção, quando os parasitos não são mais encontrados ou são insignificantes no hospedeiro, se comparados na doença aguda, onde inexistem danos cardíacos ou digestivos em pacientes assintomáticos. Outro fato importante que esta teoria não consegue explicar é o porquê de $2 / 3$ dos pacientes chagásicos crônicos não desenvolverem qualquer sintomatologia da doença. 


\subsubsection{Teoria neurogênica ou parassimpaticopriva}

A teoria neurogênica trabalha com a hipótese de que o processo de infecção do T. cruzi no hospedeiro destrói células ganglionares parassimpáticas nos tecidos parasitados, isso resultaria numa perda de neurônios do parassimpático durante a fase aguda da doença. Essa teoria é apoiada no fato da localização das fibras parassimpáticas estarem na parede dos órgãos parasitados, em maior proximidade da reação inflamatória provocada pela presença do parasito. Já os neurônios dos gânglios simpáticos estão distantes do tecido muscular parasitado e não sofreriam alterações significativas (Marin-Neto, 2007). Desta forma, esta teoria explicaria o desenvolvimento tardio dos sintomas do paciente na fase crônica, mas encontra muita dificuldade em explicar os casos de pessoas que falecem em decorrência de cardiopatia crônica com intenso comprometimento cardíaco, mas com população neuronal normal; ou ainda, de casos de pacientes que em vida tinham função miocárdica normal, e, após morte acidental, é constatada extensa destruição neuronal no tecido cardíaco.

\subsubsection{Teoria da autoimunidade}

Um dos aspectos mais intrigantes na patogenia da doença de Chagas são os processos inflamatórios extensos no coração na ausência do parasito no tecido. Segundo a teoria da autoimunidade, as lesões são desencadeadas pelos linfócitos reativos contra o próprio corpo (Santos-Buch e Teixeira, 1974). A reatividade contra o próprio tecido é característica de subpopulações de linfócitos $T$ que tiveram o genoma modificado pelas mutações de kDNA do $T$. cruzi. A atividade lítica dos linfócitos $T$ mutados com sequências de kDNA não ocorre em todos os pacientes, e esta é uma característica das doenças genéticas, tal como a distrofia muscular de Duchenne, em que vários membros de uma família têm a mutação no gene da distrofina, porém, apenas alguns desses indivíduos têm a doença muscular e cardiopatia autoimune. Sugere-se que a ativação dos linfócitos $T$ citotóxicos pode estar associada à sinalização intragenômica, que se faria cumulativamente entre diferentes sítios do DNA com alterações tri-dimensionais de complexidade crescente, oriundas das mutações de kDNA (Teixeira et al., 2011b; Guimaro et al., 2014). Esta hipótese explicaria me- 
Ihor o fato das lesões nos tecidos aparecerem tardiamente durante a fase crônica da doença, após algumas décadas, independentemente do tecido estar parasitado ou não.

\subsection{Doença de Chagas e autoimunidade}

A fase crônica sintomática da doença de Chagas se inicia quando a relativa estabilidade patológica, presente durante a forma indeterminada da infecção, é quebrada por motivos ainda desconhecidos, quando a inflamação, a necrose e a fibrose passam a ser mais intensas, difusas e progressivas no tecido cardíaco (Teixeira et al., 2006b).

A relação entre doença de Chagas e autoimunidade foi observada pela primeira vez em 1974, por Santos-Buch e Teixeira. A partir de então outros estudos também evidenciaram que a autoimunidade está envolvida na patogênese da doença de Chagas. Esses estudos indicam que a integração do kDNA do parasito no material genético do hospedeiro, ou mutações via transferência gênica horizontal, estão envolvidas nos mecanismos autoimunes presentes na doença de Chagas (Nitz et al., 2004; Teixeira et al., 2006a; Teixeira et al., 2011b; Guimaro et al., 2014).

A evidência experimental aponta que, após a intensa miocardite da fase aguda da doença de Chagas, quando a parasitemia e o parasitismo tissular já estão em baixos níveis, a inflamação regride, mas persiste de forma focal com baixa intensidade durante toda a forma indeterminada da doença (Guimaro et al., 2014).

Alguns fatores são descritos como determinantes na severidade da doença: carga parasitária, cepa do parasito ou seu tropismo tecidual, tempo de infecção e componentes genéticos do hospedeiro. Além disso, admite-se que, a vigência de mecanismo adequado de imunorregulação, seria o fator crucial para se diferenciar os indivíduos que controlariam sua infecção sem desenvolver dano tecidual importante, a partir de resposta inflamatória limitada daqueles que evoluiriam com doença grave, com inflamação intensa, necrose e fibrose reativa (Andrade et al., 2011). Entretanto, faltam evidências sugestivas desse mecanismo imunorregulador.

A teoria de que a reação do sistema imunológico à infecção por $T$. cruzi esteja envolvida como mecanismo fundamental na ocorrência das lesões ocasionadas 
durante a fase crônica da miocardite chagásica crônica apoia-se em extensa gama de evidências experimentais e clínicas descritas a seguir:

Em seu estudo, Teixeira et al.,(1991) identificaram a presença de DNA acessório do T. cruzi em macrófagos peritoneais de camundongos infectados e identificaram a origem desse DNA exógeno pela hibridização in situ com sonda homóloga. Em outro trabalho, foi documentado que sequências de minicírculos do kDNA de $T$. cruzi eram transferidas para o DNA genômico de células mantidas em cultura (Teixeira et al., 1994).

Já em 1996, Argañaraz demonstrou que linhagens de macrófagos de camundongos adquiriram horizontalmente sequências de minicírculos kDNA de $T$. cruzi preferencialmente ligadas a elementos retrotransponíveis do hospedeiro. Outro achado importante foi obtido por Simões-Barbosa et al., (1999), onde foi demonstrado que a transferência de sequência de kDNA de $T$. cruzi é capaz de alterar a expressão gênica das células hospedeiras.

Outro fato que comprova que a reação imunológica é um dos principais mecanismos responsáveis pelos danos cardíacos do hospedeiro, e que esta reação é estimulada pela presença do DNA do parasito no tecido cardíaco, foi descrita no trabalho de Olivares-Vilagómez et al., (1998). Neste estudo, o autor detectou a presença de DNA do T. cruzi disseminado por todo o coração de pacientes na fase crônica e também na fase indeterminada da doença. Os autores sugerem que a severidade dos danos que ocorrem no coração dos pacientes com doença de Chagas seja dependente da quantidade de DNA do T. cruzi remanescente neste tecido após intenso parasitismo da forma aguda. Posteriormente, Simões-Barbosa et al., (1999) demonstraram a inserção do kDNA de T. cruzi em meio a região codificante do gene P9. Essa inserção foi mediada por um elemento retrotransponível (LINE- 1), e levou ao nocaute do gene, como consequência da ausência da expressão de uma proteína na célula infectada.

Trabalhos conduzidos pela equipe de pesquisadores do Laboratório Multidisciplinar de Pesquisa em Doença de Chagas da UnB (LMPDC), demonstraram que o DNA mitocondrial (kDNA) do T. cruzi integra em diversos sítios do genoma do hospedeiro vertebrado, como consequência da infecção (Teixeira et al., 1994, Teixeira et al., 2011b). Foi demonstrado também que segmentos de 
minicírculos do kDNA do parasito integram frequentemente em retrotransposons LINE-1 em humanos, aves e coelhos (Nitz et al., 2004).

Teixeira et al., (2006b) observaram que, mesmo depois que animais experimentalmente infectados foram tratados com nitroderivado tripanocida, diminuindo a parasitemia do hospedeiro, as fibras cardíacas continuavam a ser rejeitadas por células efetoras do sistema imune e demonstrou mais uma vez a ideia da presença de um perfil autoimune na doença de Chagas.

A integração do kDNA do $T$. cruzi no genoma de hospedeiro humano foi documentada por Nitz et al. (2004) e por Hecht et al., (2010), onde demonstraram que a integração ocorria principalmente a partir de elementos retrotransponíveis LINE-1 em vários cromossomos diferentes. Nesse estudo, os autores demonstraram que a diversidade genética dos animais e humanos adquirida ao longo de sua evolução ocorreu também por transferência horizontal de material genético entre organismos eucariotos. O primeiro estudo foi um marco para a ciência, pois rompeu o paradigma de que somente os procariotos (vírus e bactérias) eram capazes de transferir parte de seu material genético para os humanos, como era conhecido até então.

Por último, Teixeira et al., (2011b) produziram doença similar a cardiopatia chagásica crônica em aves refratárias a doença. Esses pesquisadores demonstraram que pintos nascidos de ovos inoculados com T. cruzi nascem sem sinal de infecção ativa, mas com o kDNA retido em seu genoma. Essas aves, livres do parasito mas com o kDNA integrado em seu genoma, desenvolveram cardiopatia semelhante a observada nas infecções pelo T. cruzi (Teixeira et al., 2011b; Guimaro et al., 2014).

Desta forma, relatos de trabalhos publicados apontam para a evidência de que as modificações fenotípicas causadas pela presença do kDNA no genoma do hospedeiro podem ser os principais fatores envolvidos no desenvolvimento dos processos de reconhecimento autoimune do hospedeiro, responsáveis pela produção de dano cardíaco durante a fase crônica da doença de Chagas. 


\subsection{Sinais Clínicos da Doença de Chagas}

\subsubsection{Infecção aguda}

Após a transmissão vetorial do T. cruzi ao humano, é comum a observação de sinais clínicos no local da entrada do parasito, que pode ocorrer no local da picada (chagoma de inoculação), ou no olho (sinal de Romaña). O sinal de Romaña ocorre quando a pessoa se infecta após coçar a região da picada contendo as fezes do inseto e leva a mão até o olho, permitindo a entrada do parasito através da mucosa.

No caso do paciente vir a desenvolver o sinal de Romaña, ele apresentará edema na região do olho, bipalpebral, unilateral, indolor, acompanhado por conjuntivite não purulenta e adenopatia satélite.

Porém, se o paciente apresentar sinal de inflamação bastante evidente no local de picada do vetor, este desenvolverá uma reação de hipersensibilidade tardia em resposta a saliva e aos antígenos do inseto vetor. O chagoma de inoculação foi descrito pela primeira vez por Mazza e Freire (1940), e caracteriza-se como uma lesão cutânea redonda avermelhada, endurecida, indolor ou pouco dolorosa de 2 a 5 cm de diâmetro e que pode ou não ulcerar.

A infecção aguda se inicia de 6 a 10 dias após a entrada do T. cruzi no hospedeiro, podendo durar de 6 a 8 semanas. Esta fase é caracterizada pela alta parasitemia do T. cruzi no paciente (Burleigh, 2011; Steverding, 2014).

Nesta fase da doença, mais de $99 \%$ dos casos é inaparente, ou seja, os pacientes não conseguem identificar qualquer sintoma. Este fato faz com que o paciente não procure o atendimento médico (Bern, 2011). Um estudo realizado com 544 indivíduos expostos a infecção natural pelo T. cruzi, indicou que apenas um terço das pessoas infectadas apresentou sintomas compatíveis com a doença aguda (Teixeira et al.,1997).

Ainda que raros, os sintomas mais comuns na fase aguda da doença compreendem febre de pequena intensidade, dores no corpo, hepatomegalia, esplenomegalia, adenomegalia, edema no rosto, membros inferiores ou generalizados, conjuntivite e diarréia. Análises laboratoriais podem evidenciar anemia, aumento na concentração de enzimas do coração e do fígado, e trombocitopenia (Tanowitz et al.,2009). Os linfonodos quando aumentados 
apresentam-se isolados, indolores, móveis e sem sinal de inflamação. O baço tem consistência normal, liso e indolor. A esplenomegalia não costuma ser acentuada e a hepatomegalia não é dolorosa à palpação. A miocardite e/ou a meningoencefalite pode aparecer durante a fase aguda em crianças com menos de cinco anos de idade, e neste caso, é indicativo de prognóstico ruim da doença e geralmente fatal (Steverding, 2014).

Segundo Rassi et al., (2010), existem diferenças no tempo do início do aparecimento dos sintomas se o $T$. cruzi for contraído por diferentes meios de transmissão. No caso das pessoas que adquirem a infecção por meio do vetor, os sintomas geralmente começam a aparecer em cerca de 1 a 2 semanas após a infecção. Mas se a infecção tiver origem pela doação de sangue infectado, os sintomas aparecerão mais tardiamente, alguns meses mais tarde.

Após a passagem da fase aguda, a doença evolui para a fase crônica, e é caracterizada por baixa parasitemia no paciente, assim como elevação dos títulos de anticorpos IgG e diminuição de lgM.

\subsubsection{Fase indeterminada da doença de Chagas}

Os pacientes que evoluíram para a fase crônica, mas não possuem qualquer sintomatologia clínica, são considerados pacientes na fase indeterminada da doença. Esta fase pode durar a vida inteira para 60 a $70 \%$ dos pacientes infectados. Outros 30 a 40\% dos pacientes infectados, após permanecerem cerca de 10 a 40 anos na fase indeterminada da doença, desenvolverão sintomatologia clínica, cardíaca ou gastrointestinal (Nunes et al., 2013; Gobbi et al., 2014). O critério utilizado atualmente para se definir um paciente que está na fase indeterminada da doença depende de resultados de teste sorológico positivo para IgG anti- T. cruzi, ou demonstração do parasito. Porém, esses pacientes não possuem sinal clínico cardíaco (sem anormalidade ao eletrocardiograma) ou digestivo da doença, e tem tamanho regular do coração, esôfago e cólon demonstrado em radiografia. Os achados histopatológicos de biópsia de pacientes durante essa fase demonstram presença de lesões inflamatórias no coração, trato digestivo e tecido muscular similar aos encontrados em pacientes durante a fase crônica da doença, mas em grau muito menos intenso (Teixeira et al., 2006b). 


\subsubsection{Infecção crônica}

A fase crônica, ou sintomática da doença, começa com o início do aparecimento das lesões teciduais provocadas pela infecção com o T. cruzi. Ainda que a grande maioria dos indivíduos infectados permaneça na fase indeterminada ao longo de toda sua vida, em aproximadamente $30 \%$ dos pacientes ocorre o aparecimento de lesões teciduais, principalmente no coração e no sistema digestivo (Steverding, 2014). Esta fase inicia-se aproximadamente 10 a 40 anos após a infecção vetorial por T. cruzi (Gobbi et al., 2014).

Dos pacientes que apresentam sintomatologia da infecção por T. cruzi, 94,5\% desenvolvem lesões no tecido cardíaco, contra apenas 5,5\% que desenvolvem a forma digestiva da doença (Teixeira et al., 2011a). Assim, se considerarmos que existem aproximadamente cinco milhões de brasileiros infectados com T. cruzi, estima-se que um milhão e meio de pessoas têm ou virão a ter comprometimento cardíaco em decorrência desta doença.

Dentre as formas de apresentação clínica durante a fase crônica da doença de Chagas, a cardíaca representa a mais importante, dada sua prevalência e gravidade no paciente (Nunes et al., 2013). Os fatores responsáveis pela evolução dos sintomas para a forma cardíaca da doença não são ainda completamente elucidados, mas sabe-se da participação de mecanismos autoimunes na fisiopatologia da doença (Hecht et al., 2010; Teixeira et al., 2012; Guimaro et al., 2014).

A miocardiopatia no paciente chagásico crônico é semelhante a miocardiopatia dilatada idiopática e tem como característica um processo inflamatório de células mononucleares multifocal. Pacientes com miocardiopatia chagásica crônica têm prognóstico pior quando comparado com pacientes com miocardiopatia dilatada idiopática (Nunes, 2013). Nesta fase da infecção, não existem evidências de que o parasito esteja envolvido no aparecimento dos sinais clínicos (Villas-Boas et al.,2004).

A inflamação crônica, de baixa intensidade mas persistente, acaba por provocar destruição tissular progressiva e fibrose extensa no coração (Andrade et al., 2011; Falchetto et al., 2015). Os achados mais comuns de pacientes com cardiomiopatia chagásica crônica são: hipertrofia do miocárdio, dilatação das cavidades cardíacas, presença de fibrose, formação de trombos, afinamento do ápice ventricular do ventrículo esquerdo e que pode culminar para formação de aneurisma apical 
(Coura, 2007). Com isso, o coração aumenta de tamanho e surgem arritmias e bloqueios atrioventriculares, além de tromboembolismo e miocardiopatia que antecipa a insuficiência cardíaca, considerada a forma mais grave de manifestação da doença (Coura e Borges-Pereira, 2010; Rassi et al., 2012).

O único achado comum a todos os casos de pacientes chagásicos é a presença de infiltrado de células mononucleares nos tecidos alvo, pois em apenas $10 \%$ desses casos são encontrados os parasitos no local da inflamação (Teixeira et al., 2006b).

Outros achados clínicos de pacientes que podem estar presentes na cardiopatia chagásica crônica são descritos por Bern (2011), e inclui bloqueio átrioventricular, taquicardia ventricular persistente, disfunção do nodo sinoatrial - culminando em bradicardia severa, formação de trombos no ventrículo esquerdo, e dilatação progressiva do ventrículo esquerdo seguido por falência cardíaca congestiva.

Depois de mais de 100 anos da descoberta da doença, a compreensão patogenia da doença de Chagas ainda requer estudos físicos-químicos sobre a sinalização entre as células efetoras e células-alvo da resposta autoimune. Atualmente, pesquisadores buscam explicar o que exatamente exacerba o processo inflamatório no tecido cardíaco.

\subsection{Diagnóstico}

A forma aguda da doença pode ser diagnosticada pela presença de parasitos circulantes em exames parasitológicos diretos de sangue periférico, tais como exame a fresco, esfregaço ou gota espessa. Se for o caso do paciente relatar sintomas a mais de 30 dias, são recomendados métodos de concentração, já que com a evolução da doença para a forma crônica ocorre o declínio da parasitemia. Os testes de concentração recomendados são o teste de Strout, micro-hematócrito ou o QBC. A presença de anticorpos IgM anti- $T$. cruzi no sangue pode indicar a doença aguda se esta for associada a fatores clínicos compatíveis (Andrade et al., 2011).

Já durante a fase crônica da doença de Chagas, devido ao motivo dos pacientes infectados apresentarem baixa parasitemia, e por serem de baixa sensibilidade, os métodos parasitológicos não são eficientes, e, portanto, não recomendados para o diagnóstico. Neste estágio da doença, o diagnóstico é 
usualmente confirmado com a detecção de anticorpos lgG anti-T. cruzi, confirmados por dois testes sorológicos distintos. Os métodos sorológicos recomendados são a Imunofluorescência Indireta (IFI), a Hemoaglutinação (HE) e o ELISA. O diagnóstico mediante testes sorológicos é bastante utilizado para detecção de anticorpos específicos contra antígenos do $T$. cruzi, oferecendo evidência indireta de sua presença no corpo do paciente infectado.

Os resultados positivos devem ser interpretados com cautela, pois é relativamente comum ocorrerem resultados falsos positivos devido à reação cruzada com antígenos de outros microrganismos, como Leishmania spp. (Vexenat et al., 1993; Gadelha et al., 2003). Em vista disso, procura-se considerar que o teste é positivo somente quando houver resultado concordante em dois exames sorológicos de princípios distintos que identificam anticorpos anti-T. cruzi (WHO, 2002).

Além dos métodos sorológicos o diagnóstico da doença tanto na forma aguda como na crônica pode ser realizado utilizando testes de xenodiagnóstico, hemocultura ou PCR. Para efeito de diagnóstico, não existem manifestações clínicas, semiológicas ou alterações em exames cardiológicos complementares que confirme a cardiopatia chagásica crônica, neste caso o clínico deverá solicitar exames adicionais supracitados para a confirmação da doença (Andrade et al., 2011).

\subsection{Ecocardiografia}

O exame ecocardiográfico em animais vem se popularizando na pesquisa experimental e clínica devido ao seu baixo custo, por ser um exame não invasivo, e à portabilidade do equipamento (Martinez-Lemus, et al., 1998). Esse exame é útil para investigar o coração sob o ponto de vista morfológico e hemodinâmico. A ecocardiografia teve seu início como uma técnica capaz de revelar estruturas normais e anormais em modo A (amplitude) e modo M (movimento). Avanços subsequentes em ecocardiografia bidimensional (2D) possibilitaram a análise da dimensão das estruturas do coração em tempo real. A gravação do modo $M$ é derivada das imagens do modo bidimensional e graficamente representa 0 movimento das estruturas cardíacas durante a sístole e a diástole (Libby, et al., 2008). 
As ondas emitidas pelo aparelho de ultrassom são parcialmente refletidas pelas estruturas cardiovasculares e é interpretado pelo aparelho em forma de linhas ou formatos que demonstram a anatomia cardíaca do paciente. Desta forma, quando as ondas ultrassônicas emitidas pelo aparelho incidem sobre uma superfície limítrofe entre duas estruturas de densidade acústicas diferentes, uma parte dessas ondas é refletida e captada pelo transdutor, que são transformadas em sinal elétrico e interpretadas em forma de linhas no vídeo do aparelho. O transdutor é formado por um cristal pizoelétrico em sua extremidade, importante tanto na emissão de ondas ultrassônicas como na recepção dos sinais refletidos; ele capta os ecos provenientes das faces limítrofes dos tecidos que são registrados graficamente no monitor do aparelho.

A escolha do transdutor adequado é pré-requisito para o sucesso do exame, pois transdutores com baixa frequência $(2,0$ a 3,5 MHz) apresentam menor resolução da imagem, porém a penetração do feixe de eco é maior. Inversamente, sondas com alta frequência $(4,0 \mathrm{a} 8,0 \mathrm{MHz})$ não têm grande penetração, porém fornecem imagem de melhor resolução, sendo mais apropriada para o uso em animais menores (Abduch et al., 2014).

O diagnóstico, prognóstico ou a determinação de fator de risco para morte ainda constitui um desafio na doença de Chagas, em parte devido à diversidade de manifestações que o paciente pode assumir (Júnior e Filho et al., 2013). Segundo os autores, a ecocardiografia é o exame que melhor pode determinar o prognóstico e a evolução da cardiopatia chagásica crônica.

O exame ecocardiográfico permite avaliar o desempenho contrátil do ventrículo esquerdo, o comprometimento do ventrículo direito, a presença de aneurismas apical ou submitral, trombos cavitários e alterações da função diastólica. Do ponto de vista ecocardiográfico, a cardiomiopatia causada pela doença de Chagas se assemelha a miocardiopatia dilatada, e é caracterizada por dilatação das câmaras cardíacas, podendo haver alterações das características do enchimento ventricular (disfunção diastólica) e, frequentemente, incompetência das valvas atrioventriculares. A maioria das miocardiopatias dilatadas são indistinguíveis etiologicamente, exceção feita à miocardiopatia chagásica, onde pode ser detectado aneurisma apical (Lima et al., 1995). 
Mesmo na fase indeterminada da doença, o exame de ecocardiograma pode demonstrar alterações de contratilidade em parede do ventrículo esquerdo. Nesta fase da doença, o exame geralmente detecta alterações sutís e com excelente prognóstico da doença. $O$ aspecto clássico do ecocardiograma durante a fase crônica da doença avançada compreende a dilatação das cavidades atriais e ventriculares, espessamento da parede do ventrículo esquerdo e insuficiência das válvulas atrioventriculares. Os aneurismas ventriculares geralmente presentes em posição apical são característicos na cardiopatia chagásica crônica e se associam ao maior risco tromboembólico e a arritmias ventriculares. Todos esses aspectos ecocardiográficos são relevantes na avaliação do prognóstico dos pacientes com cardiopatia chagásica crônica (Andrade et al., 2011).

Sánchez-Montalvá et al., (2016) recomendam que a eletrocardiografia seja o primeiro exame a ser realizado para triagem da existência de comprometimento cardíaco em pacientes infectados com o T. cruzi. A partir daí, se houver sinais de anormalidades nesse exame, recomendam a ecocardiografia para avaliar a extensão e gravidade dos danos no coração. Martinez-Lemus et al., (1998) afirmaram que repetidas avaliações ecocardiográficas em tempos cronológicos distintos podem ser úteis na avaliação da evolução de doenças cardíacas.

\subsection{Tratamento}

É sabido atualmente que o protozoário T. cruzi necessita de alguns tipos de esteróis em todos os estágios do seu ciclo de vida para sobreviver e que é extremamente sensível aos compostos inibidores da biossíntese do ergosterol. Pesquisas in vitro desenvolvidas no Brasil demonstram certa eficácia de alguns antifúngicos como o itraconazol e o cetoconazol que atuam na inibição da síntese do ergosterol. Entretanto esses medicamentos falham na eliminação completa do parasito e também não previnem a progressão das lesões típicas da fase crônica da doença em animais ou humanos (Urbina e Docampo, 2003).

O tratamento preconizado e atualmente validado para a doença de Chagas consiste no uso de tripanocidas compostos de nitroderivados, o Benzonidazol ( $\mathrm{N}$ benzyl-2-(2-nitro-H-imidazol-1-yl)acetamide), e Nifurtimox (4-(5-nitro-3-methylfurphurylideneamino)-tetrahydro-4-H-1, 4-thiazine-1-1-dioxide) (Bern, 2011). No Bra- 
sil o benzonidazol é atualmente a única droga disponível para comercialização. A partir da década de 1980, o nifurtimox teve sua comercialização interrompida, primeiramente no Brasil e depois em outros países da América do Sul, possivelmente em razão do efeito tripanocida menor em algumas regiões endêmicas (Oliveira et al., 2008). Estudos demonstram que apesar de reduzirem substancialmente a parasitemia durante a fase aguda da doença (Urbina e Docampo, 2003), esses medicamentos não possuem eficácia durante a fase crônica.

Em um desses trabalhos, Lauria-Pires et al., (2010) demonstraram que o tratamento de 91 pessoas portadores da doença de Chagas na fase crônica não foi capaz de eliminar o parasito. Estes autores realizaram o diagnóstico molecular por PCR com uso de primers que se anelam com DNA nuclear do T. cruzi e evidenciaram infecção ativa nesses pacientes. Ao monitorar a evolução da doença nos pacientes pelas análises de exames de ECG e ecocardiografia dez anos após o tratamento, eles concluíram que não foi possível identificar efeito benéfico do tratamento específico. Em resumo, os pesquisadores puderam concluir que os pacientes tratados com os nitroderivados Benzonidazol e Nifurtimox não obtiveram melhora nos parâmetros eletrocardiográficos quando comparado com pacientes não tratados, e que na verdade esses tratamentos são ineficazes.

Não se sabe ao certo qual o motivo da melhor eficiência desses antiparasitários no tratamento da forma aguda da doença. Em seu estudo, Urbina e Docampo (2003) relatam que $80 \%$ ou mais dos pacientes crônicos tratados continuam apresentando sorologia positiva e evolução dos sinais clínicos da doença.

Além do fato da ineficiência desses medicamentos na fase crônica da doença, os pacientes tratados apresentam reações adversas importantes (Urbina e Docampo, 2003; Lauria-Pires et al., 2010). As reações adversas são comuns durante o tratamento com ambas as drogas e compreendem: neuropatia periférica, fraqueza muscular, cefaleia, náuseas, vômito, distúrbios visuais e mentais, formigamento, prurido, dermatite, descamação cutânea, anorexia, perda de libido, hiperalgesia, perda de peso, e também depressão da medula óssea - no caso do benzonidazol. Por esse motivo, torna-se obrigatório o acompanhamento médico durante toda a fase de tratamento do paciente, sendo comum a determinação da suspensão do tratamento antes de sua conclusão. 
Imai et al., (2015) relatam um caso envolvendo uma imigrante do Brasil que foi para o Japão e que desenvolveu complicações cardíacas 16 anos após sua chegada nesse país. A paciente precisou suspender o tratamento com benzonidazol 56 dias após seu início, devido ao aparecimentode neurites periféricas (parestesia nos braços, mãos e nos pés). Em outro estudo, envolvendo 32 pacientes que deveriam receber o tratamento com benzonidazol durante 60 dias, Pontes et al., (2010) relataram que $28(87,5 \%)$ desses pacientes tiveram reações adversas com uso deste medicamento e que $25 \%$ deles tiveram que interromper o tratamento antes de seu final. As reações mais frequentes encontradas neste estudo foram: prurido (50\%), formigamento $(43,8 \%)$, fraqueza muscular $(37,5 \%)$, e exantemas ou erupções cutâneas avermelhadas $(31,3 \%)$.

O tratamento com nitroderivados na fase crônica tardia da doença de Chagas é desaconselhado, pois, além da grande toxicidade apresentada no tratamento de pacientes, o seu uso não previne o aparecimento das lesões ou a evolução delas no coração dos pacientes (Teixeira et al., 2011b; Morillo et al., 2015).

Pesquisadores canadenses e brasileiros criaram um grupo de pesquisa, o BENEFIT, e que estudaram os benefícios do benzonidazol para tratamento da doença de Chagas crônica. Esse grupo fez o acompanhamento de 2854 pacientes com cardiopatia chagásica crônica que receberam o tratamento do benzonidazol na dose recomendada e concluíram que apesar de reduzir o número de parasitos circulantes no sangue dos pacientes, o tratamento não teve efeito significativo sobre os danos no coração, ou não preveniram a evolução da cardiopatia (Morillo et al., 2015).

Já o tratamento de suporte aos sintomas da doença depende das manifestações clínicas, tanto na fase aguda como na crônica. No tratamento de suporte preconizado para pacientes com alterações cardiológicas, são usadas as mesmas drogas que para outras cardiopatias, tais como cardiotônicos, diuréticos, antiarrítmicos e vasodilatadores. Nas formas digestivas da doença, pode ser indicado tratamento conservador (dietas, laxativos, lavagens) ou cirúrgico, dependendo do estágio da doença (Brasil, 2010).

As drogas atualmente preconizadas para o tratamento da doença de Chagas, nifurtimox e benzonidazol, são ineficazes para o tratamento da evolução da cardiopatia chagásica crônica e são muito tóxicas ao organismo humano, com aparecimento de reações adversas importantes no paciente tratado. Por esse motivo, novas 
drogas ou novas formas de tratamento mais eficazes devem ser descobertas para o tratamento dessa morbidade que atinge milhões de pessoas infectadas no Brasil e no mundo (Fonseca-Berzal et al., 2016).

Enquanto os pacientes da doença de Chagas aguardam o desenvolvimento de medicamentos mais eficientes e de menor toxicidade para a eliminação do T. cruzi, os cientistas têm avançado em uma nova estratégia no tratamento da doença, na tentativa de reparar ou diminuir os danos causados ao miocárdio de pacientes com a forma cardíaca crônica. É a chamada medicina regenerativa, que consiste na utilização de células tronco pluripotentes e que permitem ao próprio organismo utilizá-las para o reparo seus tecidos e órgãos lesados. A célula-tronco é uma célula indiferenciada, capaz de originar outras células-tronco (autorregeneração) e também em se diferenciar, podendo dar origem a diversos tipos celulares como cardiomiócitos e neurônios. Estas células se integram em todos os tecidos de um organismo adulto e possuem potencial de diferenciação em qualquer tipo celular do organismo, seja uma célula da pele, células cardíacas, ou um neurônio; fato este demonstrado quando células tronco embrionárias foram marcadas e reintroduzidas em embriões de camundongo (Rassi et al., 2010).

As células tronco da medula óssea são ditas pluripotentes, pois têm a habilidade de se diferenciarem em diversos tipos celulares, a depender do tipo de tecido adjacente e fatores de diferenciação envolvidos (Guarita-Souza et al., 2006). A forma como as células pluripotentes transplantadas migram para o tecido cardíaco lesado é ainda desconhecida, mas supõe-se que a resposta inflamatória persistente no local leve a liberação de citocinas, que sinalizam o recrutamento das células de medula óssea transplantadas na periferia para o tecido cardíaco (Villas-Boas et al.,2004).

Muitos tecidos e órgãos do corpo humano, tais como o fígado, o músculo esquelético, o pâncreas, e o sistema nervoso, têm um estoque de células-tronco com capacidade de regeneração tecidual após injúria. Sabe-se que as células-tronco presentes nestes órgãos são não apenas multipotentes, no sentido de que podem gerar as células constitutivas daquele órgão de origem, mas também são pluripotentes, no sentido de que também podem gerar células de outros órgãos e tecidos.

As células-tronco adultas são abundantes na medula óssea dos indivíduos e, possibilita evitar os problemas de rejeição imunológica nos casos de transplante au- 
tólogo. Ferrari et al., (1998) demonstraram que, ao injetar células de medula óssea de camundongos no músculo esquelético lesado quimicamente, as células medulares injetadas eram capazes de se diferenciar em miócitos no ambiente da lesão muscular. Em um estudo desenvolvido por nosso grupo de estudo, Guimaro et al. (2014) constataram que aves cardiopatas com lesões no coração induzidas pela presença do kDNA do $T$. cruzi em seu organismo tiveram diminuição da inflamaçãoconfirmada por histopatologia após tratamento com transplante de medula óssea isogênica.

\subsection{Modificação do genoma de aves pela integração de sequências de minicírculos de kDNA de Trypanosoma cruzi}

Estudos recentes de nosso grupo indicam a presença de sequências de minicírculos de kDNA nos genomas de aves nascidas de pintos inoculados com $T$. cruzi (Figura 1). Nesses estudos, os animais controles eram originários de ovos inoculados apenas com o meio de cultura, e não continham as sequências de minicirculos de kDNA integradas no genoma. As bandas contendo o kDNA integrado foram identificadas com sonda radiomarcada de kDNA com 330 pb (Teixeira et al., 2011b; Guimaro et al., 2014). 
A

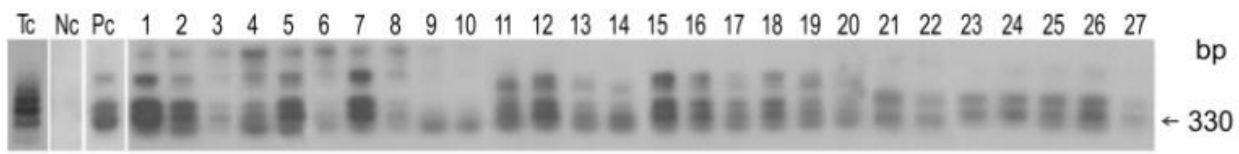

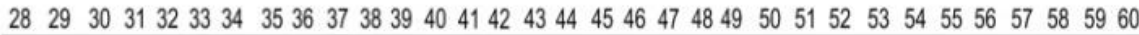

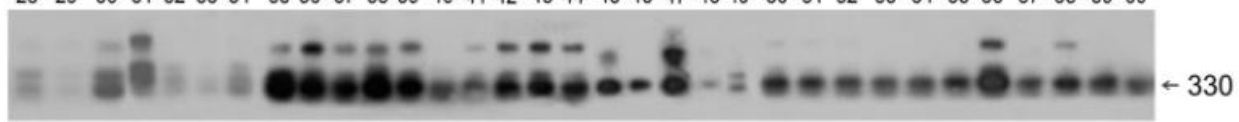

B

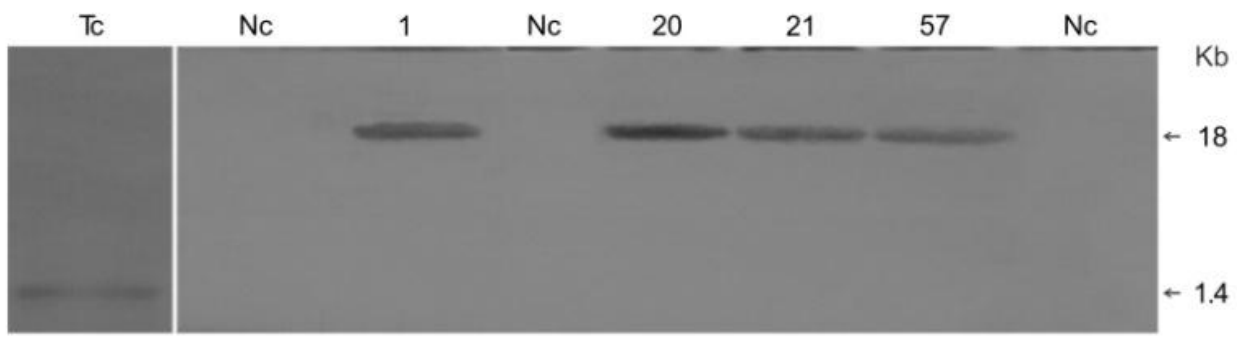

C

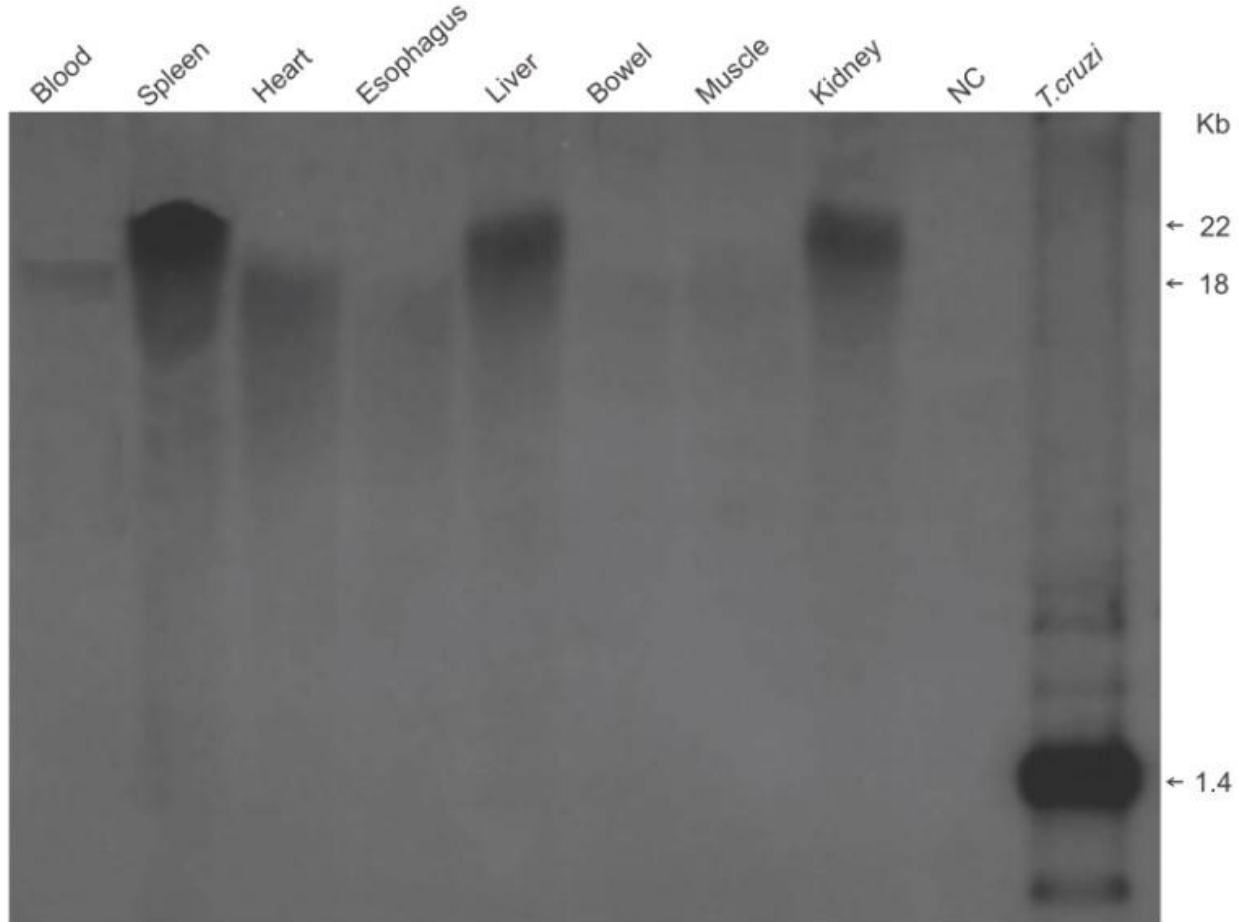

Figura 1. Modificação do genoma de aves singênicas pela integração de sequências de minicírculos de Trypanosoma cruzi. A) Amplificação pela PCR das sequências de minicírculos nos genomas de aves kDNA+ nascidas de ovos inoculados com T. cruzi. NC, controle negativo; Pc, controle positivo. Números 1 a 60 , aves kDNA+. B) Hibridização Southern blot de fragmentos de digestão EcoRI de DNA de células mononucleares do sangue de aves kDNA+, demonstrando bandas de $18 \mathrm{~kb}$. C) Hibridização de fragmentos de digestão com EcoRI de células somáticas de um galo $\mathrm{kDNA}+$, mostrando bandas de 18 a 20kb; Nc, controle negativo. O controle positivo ( $T$. cruzi) mostra uma banda principal de 1.4 kb. Fonte: Doi:10.1371/jornal.pntd.0003384.g002. 


\subsection{Aves Gallus gallus como modelo experimental em doença de Chagas}

As aves são naturalmente refratárias à infecção por T. cruzi Nery-Guimarães e Lage, 1972). O desenvolvimento da infecção ativa por T. cruzi nas aves somente ocorre quando estas estão ainda em estágio embrionário, entre o primeiro e o décimo dia de incubação do ovo (Teixeira et al., 2011b). Durante este período, o parasito consegue se multiplicar e inserir o seu kDNA no DNA genômico do embrião. Com o desenvolvimento do embrião e do seu sistema imune, a infecção se extingue, permanecendo o kDNA do parasito nas células parasitadas (Teixeira et al., 2006b; Alves, 2010; Hecht et al., 2010; Teixeira et al., 2011b; Teixeira et al., 2012; Guimaro et al., 2014). Desta forma, este modelo animal permite avaliar o desenvolvimento e a progressão da doença desencadeada pela presença do kDNA exógeno proveniente do $T$. cruzi, sem a possibilidade da patogenia gerada pela presença do T. cruzi no organismo hospedeiro (Figura 2).

Pioneiro na linha de pesquisa da autoimunidade na doença de Chagas, o Laboratório Multidisciplinar de Pesquisa em Doença de Chagas (LMPDC) produziu uma série de pesquisas para elucidar e entender a patogenia da doença. O presente trabalho é uma extensão de outros que seguiram a mesma linha de raciocínio dos efeitos da autoimunidade na gênese da doença de Chagas. Devido a isso, os resultados desses estudos anteriores serão citados a seguir para melhor compreensão do todo. 

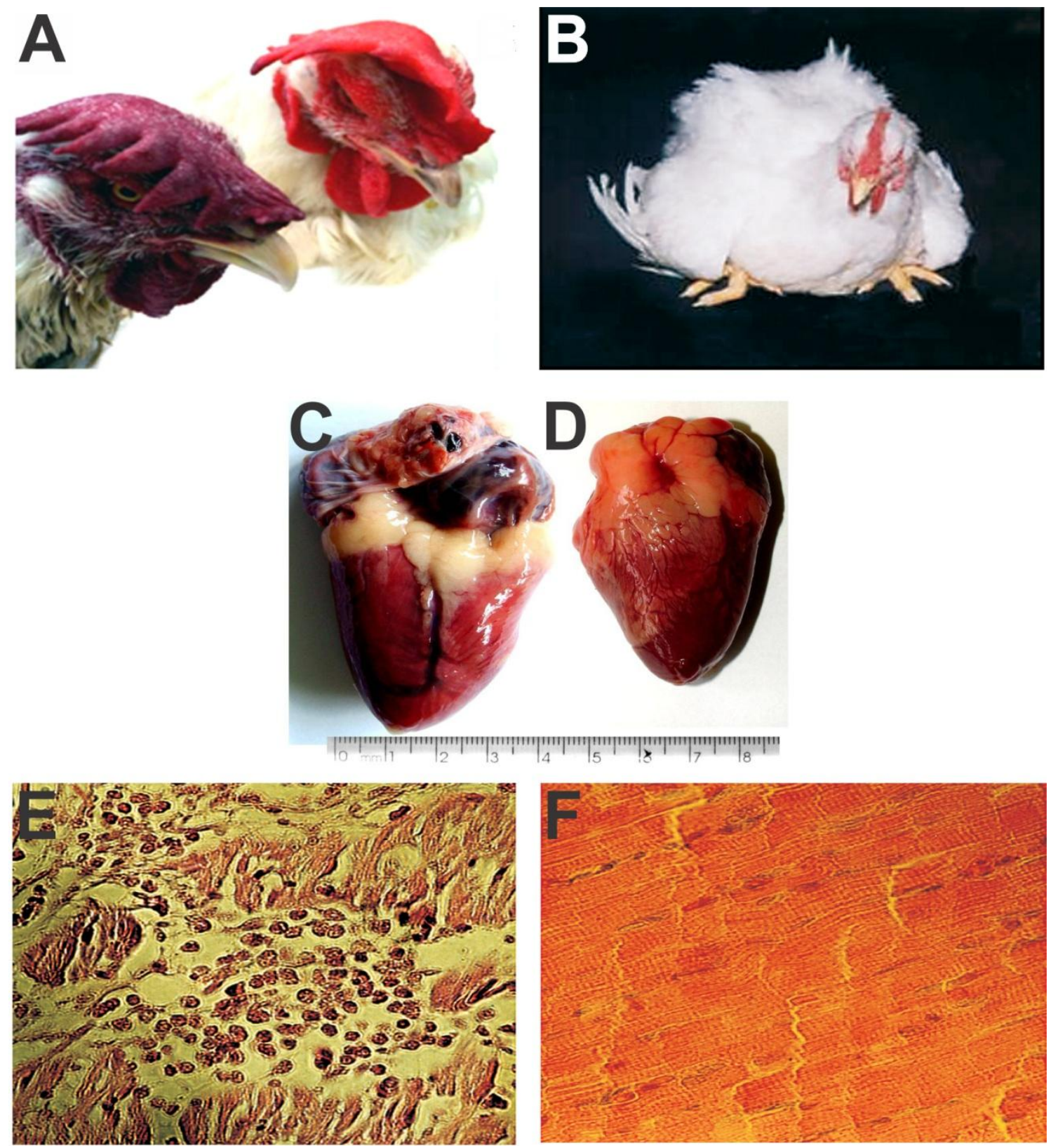

Figura 2. Aspectos clínicos da ave adulta infectada experimentalmente com T. cruzi ainda em estágio embrionário. A) Cianose; B) Fraqueza muscular; C) Coração de ave infectada experimentalmente com T. cruzi; D) Coração de ave saudável; E) Imagem microscópica mostrando intensa reação inflamatória no tecido cardíaco da ave experimentalmente infectada com T. cruzi; F) Imagem microscópica do tecido cardíaco de ave controle.

Fonte: Teixeira et al., 2006b; Teixeira et al., 2011b.

Para obtenção de animais kDNA positivos (kDNA+), é necessário a inoculação de $T$. cruzi no interior dos ovos embrionados, quando os embriões são ainda incapazes de debelar a infecção. A confirmação de que as aves nascidas de ovos 
inoculados com $T$. cruzi adquiriram sequências de kDNA do parasito foi demonstrada em trabalhos anteriores (Teixeira et al., 1991; Nitz et al., 2004; Teixeira et al.,2011b; 2012; Guimaro et al., 2014). Nesses estudos, o diagnóstico da retenção do kDNA foi obtido por meio de amplificação das bandas de minicírculos de kDNA de 330 pb, obtidas com os pares de primers S35/S36, isoladas de amostras de DNA extraído do sangue das aves cujos ovos foram inoculados com $T$. cruzi no primeiro dia de estágio embrionário. A confirmação de que o kDNA estava realmente integrado no genoma das aves, foi realizada por sequenciamento dos amplicons de $330 \mathrm{pb}$ (Teixeira et al., 2012).

\subsubsection{Sinais clínicos desenvolvidos pelas aves mutadas}

A patogênese da cardiopatia autoimune em aves mutadas com kDNA de $T$. cruzi foi descrita na tese de doutorado de Gomes, C., Universidade de Brasília, 2008. Sabendo que as aves são refratárias ao T. cruzi, é sugestivo admitir que o diagnóstico molecular positivo de kDNA determina que este material genético foi transferido e está integrado no genoma do animal, visto que as sequências de minicírculos de kDNA só podem persistir no organismo das aves se estiverem integradas em seu genoma.

A amplificação, seguida por sequenciamento do kDNA integrado mostrou que os minicírculos integram com maior frequência em elementos transponíveis CR1 no genoma das aves. Estes estudos também demonstraram que as sequências integradas de minicirculos de kDNA são transmitidas verticalmente dos parentais para as progênies, tal como ocorre nas mutações (Teixeira et al., 2011b; Guimaro et al., 2014).

Análises imunohistoquímicas do coração de aves adultas que foram inoculadas com $T$. cruzi em estágio embrionário demonstraram que havia rejeição no coração dessas aves, dados que evidenciaram uma origem genética para a cardiopatia desenvolvida por esses animais (Guimaro et al., 2014). Neste estudo, foi verificado que as lesões nas aves mutadas são produzidas predominantemente por linfócitos $T$ CD8 citotóxicos que destrói as fibras cardíacas do coração adulto. 
Os estudos conduzidos no Laboratório Multidisciplinar de doença de Chagas têm demonstrado que aves nascidas de ovos infectados experimentalmente com o T. cruzi podem ser assintomáticos ao longo da vida (Teixeira et al., 2011a). Porém, aves oriundas de ovos inoculados com $T$. cruzi, podem desenvolver cianose de crista e barbela, fraqueza muscular generalizada, e, nos casos mais severos, falecem com insuficiência cardíaca (Figura 2A e 2B). Estudos anteriores demonstraram que a autoimunidade está envolvida na patogenia da doença cardíaca na ausência do parasito, desenvolvida pelas aves com mutação de kDNA em seu genoma (Teixeira et al., 2011a; 2011b; Guimaro et al., 2014).

\subsection{Enxerto de tecido cardíaco}

Os experimentos dos enxertos de coração de pinto de um dia de vida foram conduzidos em trabalhos anteriores com o intuito de demonstrar que pequenas diferenças no genoma das aves, tais como presença ou não de fragmentos de kDNA, podem atuar como fator de rejeição e estimular células do sistema imune a atacar essas células modificadas (Teixeira et al., 2011b; Guimaro et al., 2014). Esses procedimentos foram conduzidos nas aves sob a anestesia com Cloridrato de xilazina $2 \%, 20 \mathrm{mg} / \mathrm{kg}\left(\right.$ Copazine $\left.^{\circledR}\right)$ e cloridrato de quetamina $10 \%, 10 \mathrm{mg} / \mathrm{kg}$, (Ketamine $^{\circledR}$ ) (Figura 3). 


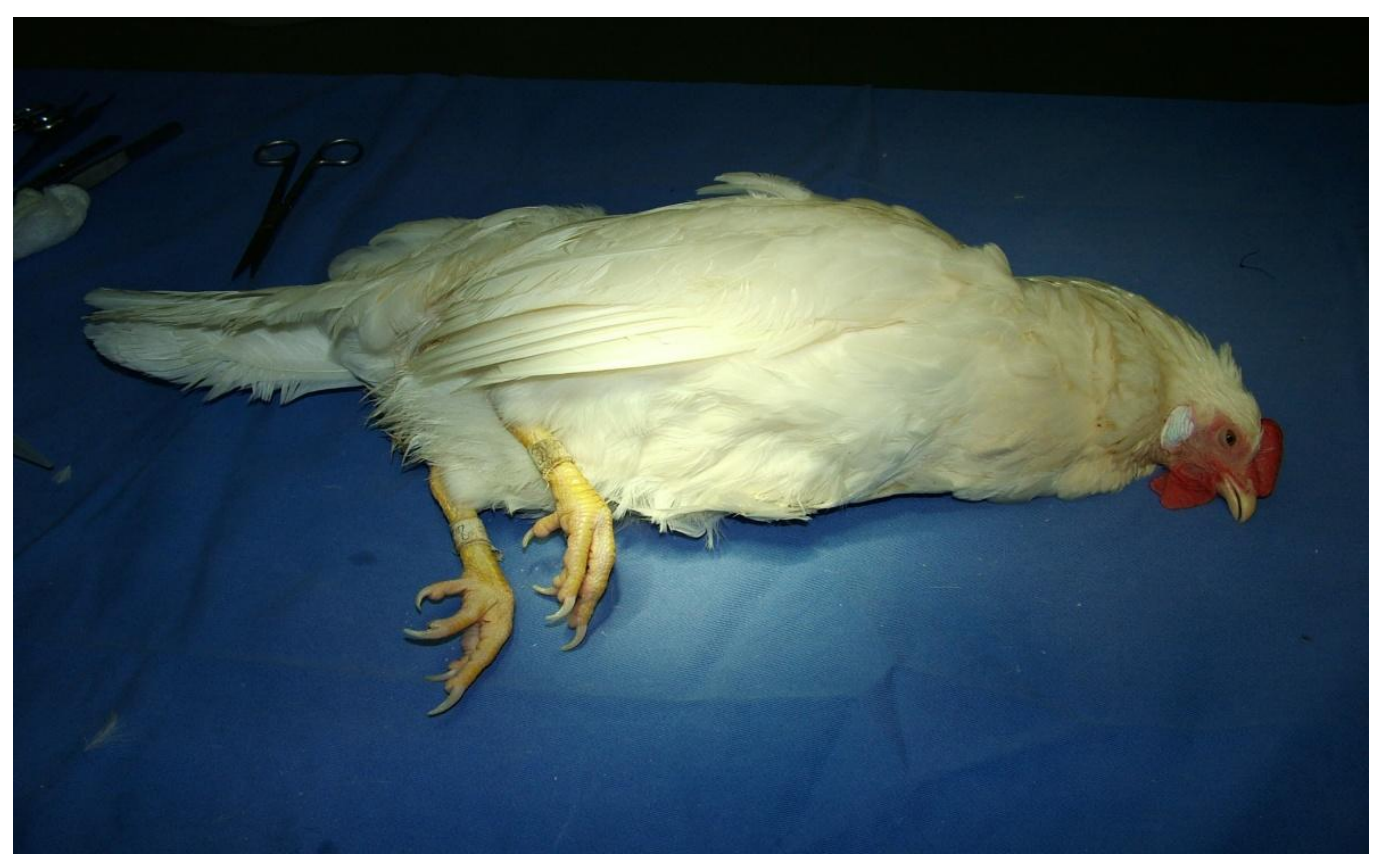

Figura 3. Ave sob anestesia com cloridrato de quetamina e cloridrato de xilazina administrados via intramuscular, previamente ao procedimento de enxerto de fragmento de coração de pinto de um dia de vida provenientes de ovos não-inoculados com $T$. cruzi (kDNA-).

Nestes experimentos uma metade do miocárdio de pinto isogênico de um dia de idade foi enxertado entre aves com haplótipos $C B\left(B^{12} / B^{12}\right)$ e entre aves com haplótipos $\mathrm{CC}\left(\mathrm{B}^{4} / \mathrm{B}^{4}\right)$ para demonstrar a integridade do mecanismo de tolerância na ausência de rejeição do enxerto singênico histocompatível, e sua ausência quando era acionada a rejeição autoimune do enxerto. Os enxertos foram implantados no tecido subcutâneo de aves com diferentes haplótipos (de CB para CC e de CC para CB) para mostrar o reconhecimento ativo do mecanismo de rejeição "non-self" na presença de genes MHC incompatíveis. Os enxertos foram inspecionados para avaliação e foram removidos nos dias 11,14 ou 17 pós-implante. A base conceitual desses experimentos está sustentada na hipótese de que a rejeição do coração chagásico é movida pelas mutações, fator genético que acirra a autoimunidade. Essa idéia levou-nos a pensar que a substituição da medula óssea da ave kDNA+ com células de medula óssea sadia de aves controle (não-mutadas) poderia inibir a autoimunidade. Para conduzir esse estudo foram usadas aves congênicas das linhagens $C B\left(B^{12} / B^{12}\right)$ e $C C\left(B^{4} / B^{4}\right)$ de forma a evitar rejeição de enxerto que pode ocorrer em modelos animais parcialmente isogênicos, ou mesmo em animais "outbred" resultantes de heterocruzamentos (Teixeira et al., 2011b; Guimaro et al., 2014). Essas linhagens de Gallus gallus são ditos congênicos poisas linhagens CB e 
CC diferem entre si apenas pelos genes do locus do complexo maior de histocompatibilidade (MHC). Entretanto, as aves de mesma linhagem são isogênicas entre sí. De maior importância, as diferenças de MHC fazem com que aves $\mathrm{CB}$ rejeitem enxerto $C C$ e vice-versa. Porém não há rejeição de enxerto de tecido entre aves da mesma linhagem. Neste experimento, as aves kDNA+ tinham perdido a tolerância imune ao tecido do seu próprio corpo e por isso rejeitaram os enxertos de coração de pinto de mesma linagem, ou isogênico. As aves kDNA- não rejeitaram os enxertos de coração de pintos de mesma linhagem.

A Figura 4 mostra a característica singênica, ou isogênica, de cada linhagem (CC ou $\mathrm{CB}$ ) de aves de Praga e mostra também a rejeição de enxertos incompatíveis entre linhagens diferentes de aves (de CB para CC ou vice-versa). Essas características entre linhagens $\mathrm{CC}$ e $\mathrm{CB}$ foram essenciais para caracterizar as respostas imunes normais e conduzir os experimentos visando à rejeição autoimune do coração de aves isogênicas mutadas com kDNA de $T$. cruzi. As modificações no genoma de aves de mesma linhagem foram introduzidas pela inoculação de $T$. cruzi nos ovos embrionados. 
A
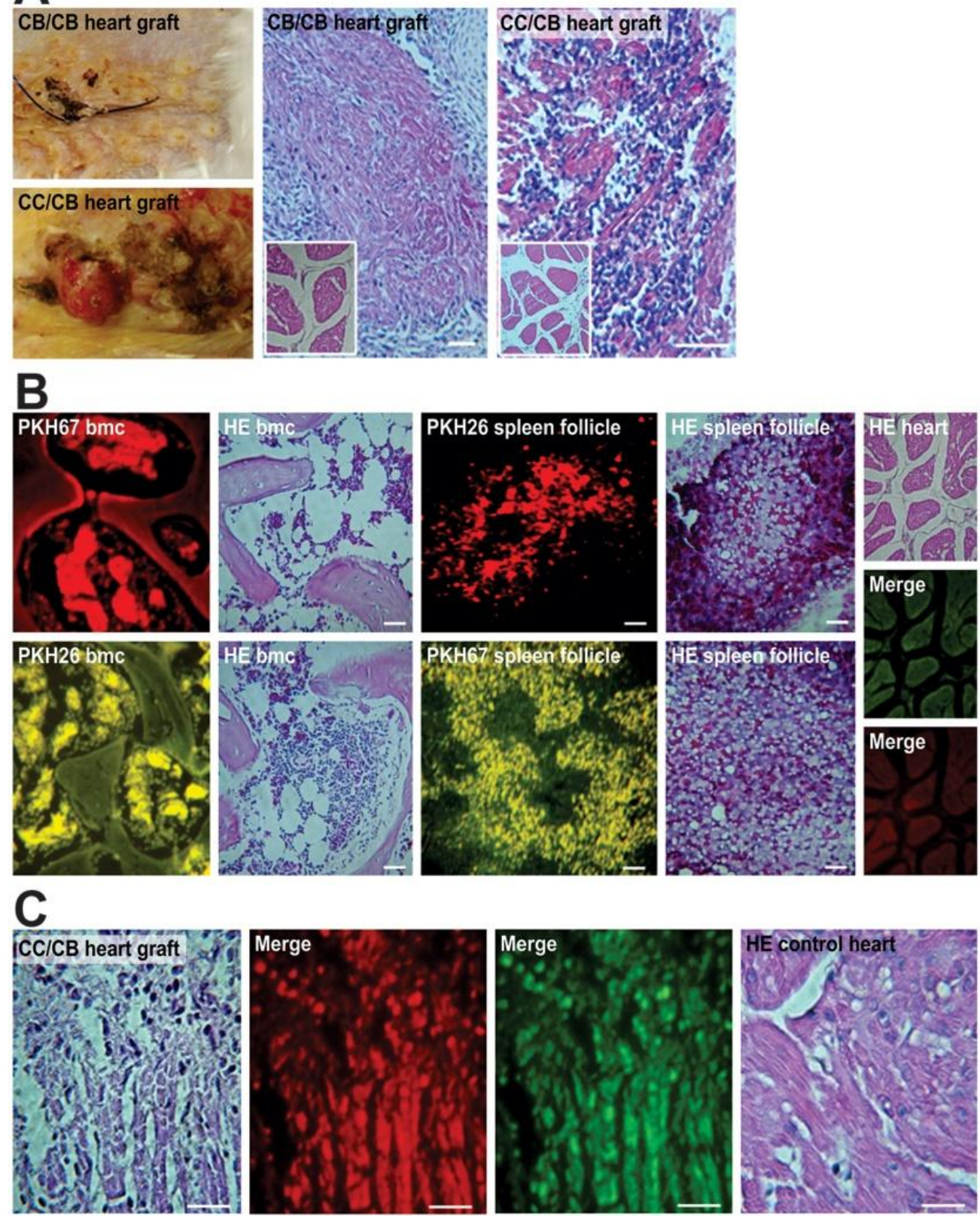

Figura 4. Reação autoimune durante a rejeição de enxertos. A) Aceitação de enxerto compatível de ave de mesma linhagem (CC ou $\mathrm{CB}$ ). Acima à esquerda, incisão cirúrgica cicatrizada e aceitação do coração repórter no tecido subcutâneo e ulceração do sítio de enxerto do coração repórter (abaixo). O miocárdio sadio compatível foi envolvido por tecido fibroso (centro) aos 17 dias. O coração incompatível exibiu necrose aos 14 dias (direita). B) Células imunes marcadas com fluorocromos. Fila de cima, células de medula óssea normais (kDNA-) e histologia de folículos linfóides do baço. Fila de baixo, células de medula óssea $\mathrm{kDNA}+$ e histologia de folículos linfóídes do baço mostrando hipercelularidade. Coluna à direita, histologia normal de coração de pinto de um dia de idade. Coloração: H-E, PkH26e PkH67. C) Rejeição de enxertode coração histoincompatível entre aves de diferentes linhagens (CB ou CC). $O$ enxerto do doador $\mathrm{CC}$ sofreu rejeição aguda pelas células imunes do receptor $\mathrm{CB}$, aos 11 dias. À esquerda, H-E, centro; Fluorocromos vermelho e verde. Direita, enxerto de coração de um dia com histologia normal. Barras, 10 $\mu \mathrm{m}$.

Fonte: http://dx.doi.org/10.1371/journal.pntd.0003384.g001 
No estudo de Guimaro et al., (2014), os autores marcaram células mononucleares do sangue de aves kDNA+ e de aves controles kDNA- com fluorocromo vermelho e verde para visualizar a distribuição de células mononucleares no organismo das aves mutadas. Para isso, foram feitas análises histopatológicas de tecidos de medula óssea, baço, e coração para avaliar a distribuição dessas células marcadas (Figura 5). Este experimento demonstrou o encontro de inflamação com linfócitos autoreativos associados com áreas de lesão no coração das aves mutadas, assim como seus efeitos na longevidade desses animais e no tamanho do coração. 

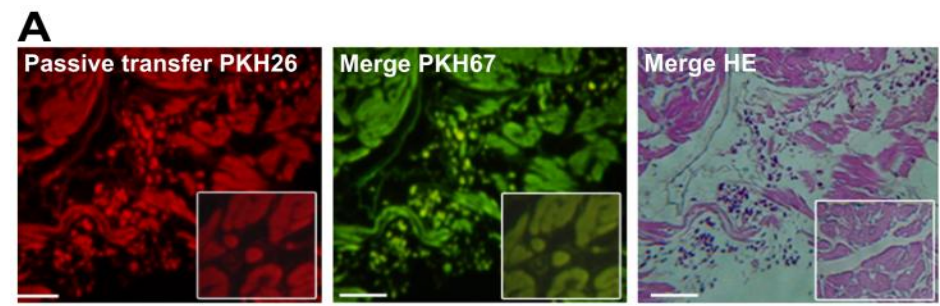

B
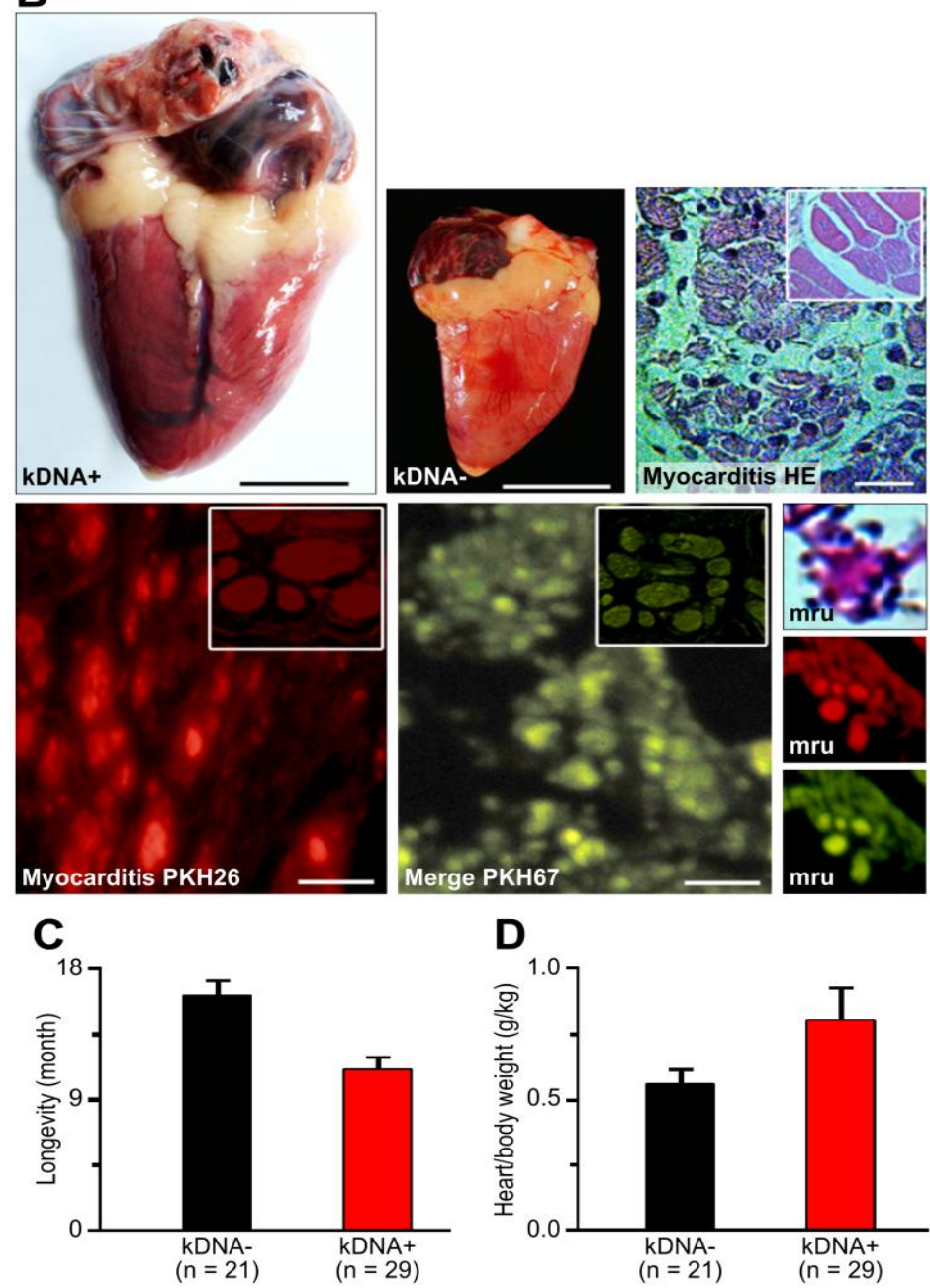

Figura 5. Patologia macro e microscópica no coração resultante das modificações do genoma de aves singênicas pelas mutações de sequências de kDNA de Trypanosoma cruzi. A) Transferência passiva de células imunes de aves singênicas marcadas com fluorocromos. As células imunes de aves kDNA+ foram encontradas em pequenos focos no coração da ave singênica receptora sadia. Barras, 5 um. B) Produção de patologia nas aves kDNA+ singênicas nascidas de ovos inoculados com $T$. cruzi, semelhante a cardiopatia chagásica em humanos. O coração da ave kDNA+ pesou 21,6 g, e o coração da ave kDNA- pesou 9,6 g. Miocardite severa estava presente no coração $\mathrm{kDNA}+(\mathrm{H}-\mathrm{E}$, à direita). A miocardite foi monitorada nas secções com marcação pelos fluorocromos (fila abaixo), e UMRs típicas estão presentes na foto do topo à direita $(\mathrm{H}-\mathrm{E})$. Barra, $10 \mu \mathrm{m}$. C) Sobrevivência (meses) de aves kDNA+e kDNA-, não mutadas. As diferenças são estatisticamente significativas $(p<0.005)$. D) Índices de peso do coração/peso corporal obtidos após a morte de aves kDNA+ e controles kDNA-. As diferenças são estatisticamente significativas. Barras: macro, $1 \mathrm{~cm}$; micro, $10 \mu \mathrm{m}$.

Fonte: Doi: 10.1371/jornal.pntd.0003384.g03. 


\subsection{Patologia nas aves e proposta de tratamento com transplante de medula óssea}

Em um estudo do grupo de pesquisa do LMPDC, a patologia foi examinada nos tecidos das aves parentais F0 e das progênies F1-F3. Secções histológicas foram confeccionadas com tecidos de coração, músculo esquelético, intestino grosso, fígado, rins e baço e corados com hematoxilina-eosina. Neste trabalho, a análise semiquantitativa da patologia inflamatória consistiu na observação do infiltrado de células imunes no coração, músculo esquelético, intestino grosso, fígado, rins, e baço de aves que morreram no curso da doença ou que foram eutanasiadas aos 10 e 20 meses de idade. A intensidade do infiltrado inflamatório nos tecidos foi avaliada pela unidade mínima de rejeição (UMR) que define a lise de célula alvo pelos linfócitos imunes (Alves, 2013).

As aves que eclodiram dos ovos inoculados com $T$. cruzi retiveram o kDNA mitocondrial do parasito em seu genoma e rejeitaram o coração, sem o parasito. O cruzamento desses parentais geraram descendentes kDNA+, e a doença cardíaca também foi documentada nessas progênies. As aves kDNA+ que morreram naturalmente ao longo dos experimentos tinham a patologia macro e microscópica. O desenvolvimento da patologia cardíaca ao longo do tempo resultou na morte precoce das aves kDNA+ aos 13,2 \pm 7 meses, enquanto as aves controles (kDNA-) sobreviveram 19,2 \pm 8 meses; esta diferença foi estatisticamente significativa (Alves, 2013).

Alternativamente ao fato da doença de Chagas ainda não possuir tratamento eficaz para eliminar o parasito, um novo conhecimento na medicina está abrindo perspectivas para o tratamento desta doença e de outras doenças crônicodegenerativas. É a chamada medicina regenerativa, que utiliza células tronco do próprio organismo para reparar tecidos e órgãos lesados, incluindo aqueles que eram considerados por muito tempo como incapazes de se regenerarem, como o cérebro e o coração. Os efeitos da terapia celular e sua utilização em pacientes cardiopatas chagásicos crônicos têm sido promissores experimentalmente e demonstram que podem levar a uma melhora funcional do coração e da qualidade de vida dos pacientes (Clarke et al., 2000; Krampera et al., 2003; Ribeiro dos Santos et al., 2004; Villas-Boas et al., 2004; Guarita-Souza et al., 2006; Guimaro et al., 2014). 
Portanto, considerando os resultados obtidos e publicados anteriormente por pesquisadores do LMPDC, neste trabalho procuramos elucidar os efeitos do transplante de medula óssea em aves singênicas. Para isso, induzimos nas aves a cardiopatia semelhante a que ocorre na doença de Chagas em humanos e monitoramos a função cardíaca de cada uma utilizando exames de ecocardiografia antes e após realizarmos o tratamento de transplante de medula óssea nestes animais. 


\section{Justificativa}

Mais de 100 anos após a descoberta da doença, ainda não há tratamento satisfatório para a doença de Chagas. Considerando a teoria de que a patogênese da cardiopatia tem como base a alteração genética que induz a autoimunidade, surge a possibilidade de interrupção no processo que causa a doença e a interrupção da gênese da autoimunidade. As modificações fenotípicas das células somáticas podem ser os principais fatores envolvidos no desenvolvimento dos processos de reconhecimento autoimune do hospedeiro, responsáveis pela produção de dano cardíaco durante a fase crônica da doença de Chagas. Seguindo o raciocínio da autoimunidade, supõe-se que a substituição de células infectadas e mutadas por células sadias a partir do transplante de medula óssea poderá ser uma importante estratégia na inibição dos sintomas da doença.

Se isso ocorre, então significa dizer que se substituirmos as células genotipicamente alteradas por células sadias (sem a inserção de kDNA exógeno proveniente do $T$. cruzi), cessará o reconhecimento da autoimunidade e, por consequência, a evolução da doença. 


\section{Objetivo Geral}

Avaliar o funcionamento do coração de aves (Gallus gallus) portadoras de kDNA exógeno de Trypanosoma cruzi submetidas ao tratamento com transplante de medula óssea.

\subsection{Objetivos específicos}

1) Induzir a mutação pela inserção de kDNA do T. cruzi no genoma das aves $k D N A+$, inoculando o parasito em ovos embrionados;

2) Acompanhar o desenvolvimento da cardiopatia chagásica nas aves kDNA+, nascidas de ovos inoculados com o T. cruzi;

3) Destruir a medula óssea das aves kDNA + com drogas citostática e antimetabólica, e substituí-las pela medula óssea proveniente de aves kDNA-sadias;

4) Destruir a medula óssea das aves kDNA- com drogas citostática e antimetabólica, e substituí-las pela medula óssea proveniente de aves kDNA+;

5) Monitorar com exames ecocardiográficos a inibição e/ou a indução do desenvolvimento da cardiopatia chagásica nas aves, antes e após o tratamento com transplante de medula óssea. 


\section{Material e métodos}

Os experimentos foram conduzidos após a obtenção da autorização do Comitê de Ética no Uso Animal (CEUA) da Universidade de Brasília, protocolo número 127989/2012.

\subsection{Modelo Animal}

O modelo animal escolhido para o desenvolvimento deste trabalho foi o de aves (Gallus gallus) refratárias ao T. cruzi (Dias, 1944; Nery-Guimarães e Lage, 1972; Kierszenbaum et al., 1976; Teixeira et al., 2011b; Roque e Jansen, 2014; Guimaro et al., 2014), ou seja, animais que não permitem a presença do parasito em seu organismo imunocompetente.

O modelo de aves (Gallus gallus) isogênicas derivadas da linhagem Leghorn foi adquirido a partir de parceria com o Instituto de Genética Molecular da Academia de Ciências de Praga, República Tcheca. Os ovos embrionados desta linhagem de aves foram gentilmente cedidos pelo professor Jiri Hejnar para serem inoculados com $T$. cruzi em nosso laboratório. Sabe-se que as aves são refratárias a infecção causada pelo $T$. cruzi, ou seja, o parasito só consegue multiplicar-se na primeira semana de desenvolvimento do embrião intra-ovo, mais precisamente até o oitavo dia de incubação, quando os animais amadurecem o sistema imune competente (Teixeira et al., 2006; Teixeira et al., 2011b).

Os ovos embrionados foram incubados em chocadeiras automáticas na Universidade de Brasília, em uma sala especialmente preparada no alojamento de animais da Faculdade de Medicina. Os primeiros animais nascidos desses ovos foram selecionados para serem matrizes das futuras gerações. Após o nascimento, estas aves foram criadas em gaiolas individuais para se desenvolverem até a idade adulta, com aproximadamente cinco meses de idade. Estes animais foram então selecionados para se tornarem matrizes, ou pais de futuras gerações F1, F2, etc. As aves foram mantidas em gaiolas individuais em sala com temperatura constante de $25^{\circ} \mathrm{C}$ e umidade a $55 \%$, e a reprodução foi obtida mediante inseminação artificial, dada a incapacidade desses animais se reproduzirem por monta natural. As aves da geração F1 foram selecionadas para formar os grupos experimentais deste estudo. 


\subsection{Reprodução das aves para formar grupos experimentais}

A inseminação artificial seguiu o método descrito por Burrows e Quinn, (1937), com adaptações. Esta técnica consiste na colheita de sêmen em tubo de vidro estéril, realizada após massagem no dorso do animal, seguida de inoculação de 0,1 $\mathrm{ml}$ desse sêmen fresco na cloaca da galinha. Esta operação é realizada manualmente por dois técnicos experientes, onde um deles segura as pernas e asas do animal enquanto o outro operador realiza o movimento de deslizar os dedos pelo dorso do animal até chegar próximo à cloaca, momento em que o animal ejacula; o sêmen é então coletado em recipiente de vidro estéril, posicionado abaixo da cloaca do animal. O conteúdo de sêmen fresco foi fracionado em doses de 0,2 $\mathrm{mL}$ aspirado com uso de seringa de $1 \mathrm{~mL}$ descartável. Cada dose de $0,1 \mathrm{~mL}$ foi injetada na cloaca da galinha. Este procedimento é realizado introduzindo a extremidade fina da seringa no interior da cloaca da galinha, que é exposta por um dos operadores com a movimentação das patas do animal em direção ao ventre, enquanto o outro operador injeta 0,1 a $0,2 \mathrm{~mL}$ do sêmen fresco. Esse procedimento foi realizado duas vezes na semana, com intervalos de 72 horas entre eles. Com este protocolo, foi obtido de cada galo um volume de ejaculado total de aproximadamente $1 \mathrm{~mL}$ e taxa de eclosão dos ovos de 60\%. É importante salientar que somente são inseminadas galinhas que estão em período reprodutivo, ou seja, ovipondo. O procedimento foi empregado para reprodução de aves controles (kDNA-) e de aves mutadas $(\mathrm{kDNA}+)$, mantidas em gaiolas colocadas em setores diferentes (Figura 6, A).

Os ovos oriundos de galinhas inseminadas foram então colhidos durante cinco dias consecutivos, de segunda a sexta-feira, tempo normalmente necessário para acumular um lote de 25 a 30 ovos. Os ovos acumulados durante uma semana foram levados até uma sala anexa à de reprodução das matrizes, a sala dos ovos. Nesta sala, os ovos foram incubados em chocadeiras do tipo automáticas, com giro dos ovos a cada 1 hora e reguladas para permanecer constantemente a $37,5^{\circ} \mathrm{C}$ e umidade do ar entre 50 e $65 \%$. Os ovos permaneceram dentro dessas chocadeiras durante 20 dias. No vigésimo dia de incubação esses ovos foram transferidos para eclodirem em outra máquina, chamada câmara de nascimento.

A câmara de nascimento foi ajustada para permanecer em $37^{\circ} \mathrm{C}$ e $60 \%$ de umidade do ar. Os pintos começam a nascer no dia seguinte, sendo que o último a 
nascer pode demorar até 48 horas após a colocação dos ovos na câmara de nascimento. Os pintos nascidos permaneceram nesse local por mais 24 horas, estando assim mais preparados fisiologicamente para manterem a homeotermia, assim como para se locomoverem, e se alimentarem. Portanto, após 48 horas do nascimento, os pintos foram transferidos para outra sala, com ciclo de luz de 12 horas, temperatura constante de $29^{\circ} \mathrm{C}$ e umidade do ar de $50 \%$. Os ovos eclodidos de aves controles eram chocados em incubadeira separada da outra que chocava apenas ovos eclodidos de aves kDNA+.

No interior desta sala, foram alocadas gaiolas de ferro de dimensão $50 \times 50 \mathrm{~cm}$, suspensas, com piso em tela de malha fina de metal. Colocou-se ainda no interior da gaiola uma lâmpada incandescente de cor verde ou vermelha de $5 \mathrm{w}$, de forma a ficar suspensa e próxima da altura dos pintos, para os animais se aquecerem se quisessem. Os pintos controles eram mantidos em gaiolas separadas das outras destinadas apenas aos pintos kDNA+. A ração foi ofertada ad libidum de acordo com faixa etária do animal: Do $1^{\circ}$ ao $30^{\circ}$ dia de vida as aves foram alimentadas com ração para frango inicial (Nutrina ${ }^{\circledR}$ inicial 210 ); do $31^{\circ}$ dia de vida até o terceiro mês de idade recebiam ração para crescimento (Nutrina ${ }^{\circledR}$ crescimento 190) e dos 3 meses de idade em diante receberam ração para poedeiras. A água era filtrada, oferecida em bebedouros suspensos, sempre a disposição dos animais.

Com um mês de idade os frangos foram selecionados e transferidos para 0 galinheiro experimental (Figura 6, B). Este galinheiro consiste em uma estrutura outdoor, toda telada, com telhado, e de piso suspenso em tela. As divisões internas de $1 \mathrm{~m}^{2}$ permitiama separação de 5 animais por compartimento. Os setores, ou Boxes do galinheiro eram separados para frangos controles (kDNA-) e outros para os frangos kDNA+.

Os frangos machos foram selecionados e transferidos em lotes de 5aves para cada box de galinheiro; dessa forma, foi mantida igual idade das aves de um mesmo grupo. Esses animais formaram os animais originalmente KDNA-, ou seja, que não possuem inserção do kDNA proveniente do T. cruzi.

Da mesma forma, os frangos que formaram o grupo dos animais kDNA positivos $(\mathrm{kDNA}+)$, foram selecionados e transferidos para outro box desse galinheiro, destinado exclusivamente às aves nascidas de ovos inoculados com o Trypanosoma cruzi. 
Portanto, os grupos experimentais $\mathrm{A}$ (controles ou kDNA-) e $\mathrm{B}(\mathrm{kDNA}+$ ) foram formados por cinco frangos de mesma idade, nascidos no mesmo dia, e com aproximadamente seis meses de idade, os galos foram submetidas ao experimento de transplante de medula óssea.

\subsection{Inoculação de Trypanosoma cruzi na câmara de ar de ovos embrionados}

Com o objetivo de produzirmos aves portadoras de kDNA exógeno, ou kDNA+, era necessário a inoculação de T. cruzi no ovo embrionado de Gallus gallus. A inoculação de $T$. cruzi em ovo fértil foi feita com formas tripomastigotas de $T$. cruzi Berenice, cultivados em meio DMEM suplementado com soro fetal bovino $5 \%$, e mantidos a $37^{\circ} \mathrm{C}$. O total de 100 tripomastigotas foi inoculado na câmara de ar de cada ovo. Para isso, a câmara de ar foi delimitada com um lápis, sob transluminação em ovoscópio (Figura 6, C). Os ovos foram então levados até uma câmara biológica e, com auxílio de instrumento em aço-inox de ponta fina esterilizado, foi feito um orifício de aproximadamente $1 \mathrm{~mm}$ na casca do ovo, sobre a câmara de ar. Então, com auxílio de uma pipeta de precisão, foram inoculados $5 \mu$ de solução salina $0,9 \%$ contendo 100 tripomastigotas através do orifício aberto na casca (Figura 6, E). Em seguida, o furo na casca do ovo foi tampado com fina camada de parafina derretida.

Essa mesma técnica de inoculação dos ovos de galinha foi descrita por Alves (2013), que obteve índice de integração do kDNA em 75\% dos animais que nasceram de ovos inoculados com $T$. cruzi. As sequências híbridas kDNA-DNA de G. gallus foram identificadas nas células somáticas (Guimaro, 2014). Nos experimentos controles, os ovos não foram manipulados, e todos os grupos experimentais seguiram o mesmo procedimento básico de incubação a $37,5^{\circ} \mathrm{C}$, com ciclos de rotação a cada duas horas em atmosfera com umidade de $65 \%$.

\subsection{Grupos experimentais}

O estudo das alterações ecocardiográficas foi conduzido em quatro grupos experimentais, contendo cinco aves cada, conforme descrito abaixo: 
- Grupo 1, Controle negativo: aves $\operatorname{kDNA}(-)$, não submetidos ao tratamento de supressão e transplante de medula óssea;

- Grupo 2, Controle do tratamento: aves $\operatorname{kDNA}(-)$ que receberam tratamento para destruir a medula óssea, e, dois dias após, receberam medula óssea de aves kDNA(-);

- Grupo 3, Indução da doença: aves $\operatorname{kDNA}(-)$ que receberam tratamento para destruir a medula óssea, e, dois dias após, receberam medula óssea de aves $\operatorname{kDNA}(+)$;

- Grupo 4, Inibição da doença: aves kDNA(+) que receberam tratamento para destruir a medula óssea, e, dois dias após, receberam medula óssea de aves $\operatorname{kDNA}(-)$. 

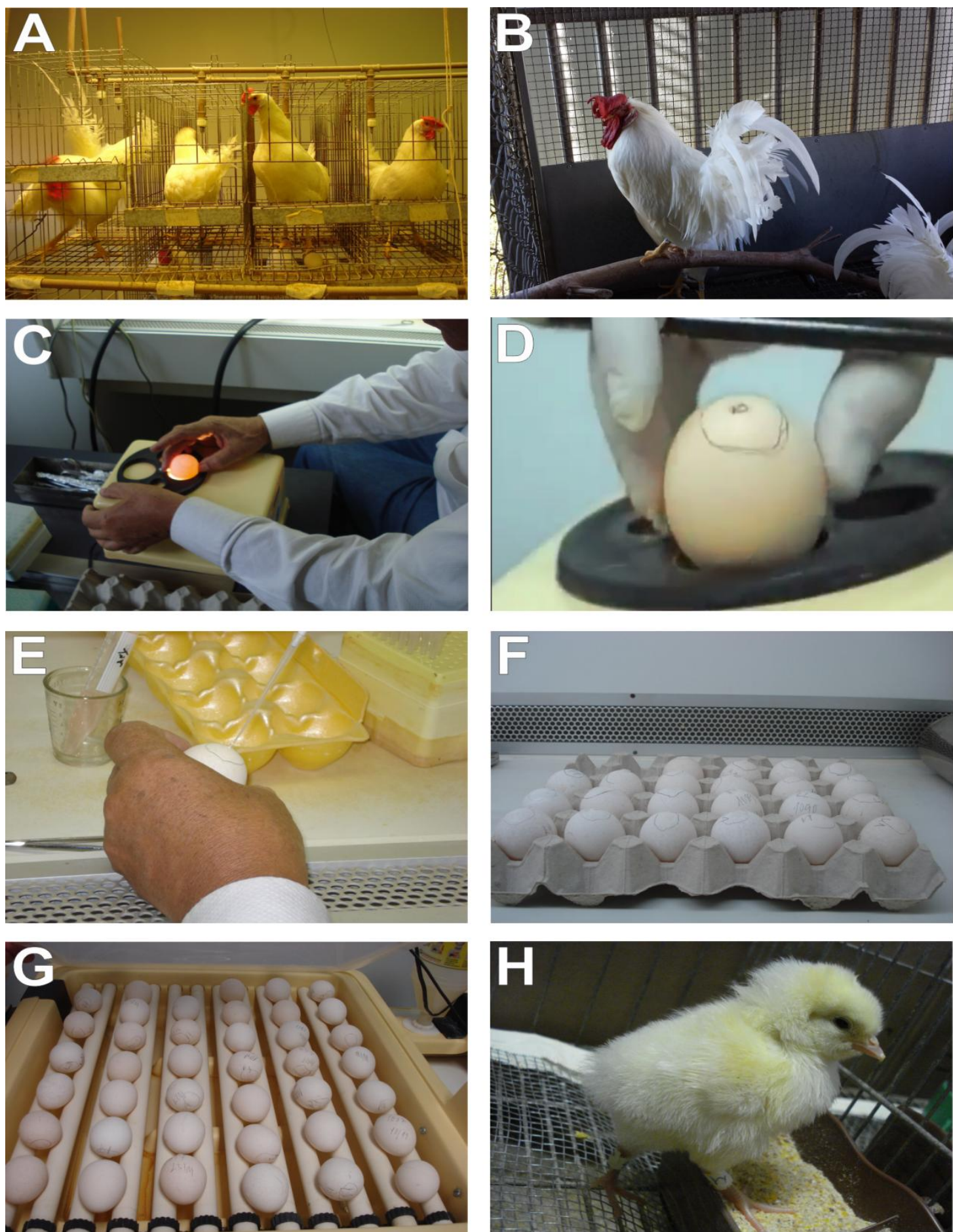

Figura 6. Inoculação dos ovos embrionados e formação dos grupos experimentais.

A) Animais matrizes (F0) em gaiolas individuais; B) Animais F1 divididos em grupos experimentais; C) Ovoscopia para visualização da câmara de ar; D) Delimitação da câmara de ar do ovo; E) Inoculação de 100 unidades de T. cruzi em cada ovo; F) Ovos inoculados com T. cruzi e ocluídos com parafina; G) Ovos inoculados em chocadeiras automáticas; H) Animal F1 oriundo de ovo infectado com T. cruzi. 


\subsection{Diagnóstico Molecular}

\subsubsection{Extração de DNA das Aves}

Com o objetivo de confirmar se a ave nascida de ovos inoculados com T. cruzi reteve o kDNA do parasito, foram feitos testes moleculares de PCR e hibridização de sondas homólogas de kDNA para identificar sua presença. A operação de punção sanguínea das aves se inicia com a contenção física das aves, realizada por um operador que segura a ave gentilmente pelas patas e asas. Um segundo operador realiza a punção a partir da veia ulnar, após assepsia do local com álcool $70 \%$, sendo coletado aproximadamente $5 \mathrm{ml}$ de sangue de cada ave.

A extração do DNA do sangue foi realizada segundo o método descrito por Sambrook e Russel, (2001). Segundo esse protocolo, as células brancas são separadas por gradiente de Ficoll-PaqueTM Plus (GE Healthcare), por centrifugação a 5000 rpm durante 30 minutos. A fração obtida foi lavada com PBS 1X pH 7,4 (3,2 $\mathrm{mM} \mathrm{Na2HPO4,} \mathrm{0,5} \mathrm{mM} \mathrm{KH2PO4;} \mathrm{1,3} \mathrm{mM} \mathrm{KCl;} 135 \mathrm{mM} \mathrm{NaCl}$ ), sendo obtido um sedimento de células lisadas, que foi suspenso em tampão de extração (1 mM TRIS$\mathrm{HCl} \mathrm{pH} \mathrm{8,0;0,1} \mathrm{M} \mathrm{EDTA} \mathrm{pH} \mathrm{8,0;} \mathrm{0,5 \%} \mathrm{SDS)} \mathrm{acrescido} \mathrm{com} \mathrm{proteinase} \mathrm{K}(100 \mu \mathrm{g} / \mathrm{mL})$, ficando incubado a $37{ }^{\circ} \mathrm{C}$ por $12 \mathrm{~h}$. Do material obtido, foi submetido à extração por três vezes com igual volume de clorofane (fenol: clorofórmio: álcool isoamílico, na proporção $25: 24: 1$ ) e uma vez com igual volume de clorofil (clorofórmio : álcool isoamílico, na proporção $24: 1$ ).

Esse procedimento foi realizado à temperatura ambiente, sob leve agitação. Após, a separação das duas fases formadas, orgânica e aquosa, realizada por centrifugação a $5000 \mathrm{rpm}$ por 15 minutos. O DNA foi precipitado em 5V de etanol $100 \%$ gelado, seguido por duas lavagens com etanol $70 \%$ gelado. Após secagem em câmara biológica, o material (DNA) é visível no fundo do tubo. Este DNA foi ressuspenso em $200 \mu \mathrm{L}$ de tampão TE (10 mM Tris-HCl pH 8,0; 1 mM EDTA pH 8,0) e RNAse $(20 \mu \mathrm{g} / \mathrm{mL})$, ficando incubado a $37{ }^{\circ} \mathrm{C}$ por $12 \mathrm{~h}$. Em seguida, o material foi guardado em freezer, a $-20{ }^{\circ} \mathrm{C}$. Os procedimentos de diagnóstico molecular e identificação das mutações nas aves parentais e nas progênies foram descritos por Alves (2013) e Guimaro et al., (2014). 


\subsubsection{Extração de kDNA de Trypanosoma cruzi}

O DNA do cinetoplasto (kDNA) extraído do T. cruzi foi utilizado com o objetivo de produzir a sonda radioativa de kDNA, necessário para realizar a hibridização, e possibilitar a confirmação da presença do kDNA nas aves nascidas de ovos inoculados com T. cruzi. Além disso, $2 \mu \mathrm{L}$ de kDNA era utilizado como amostra de controle para as reações de PCR. Para extraí-lo, o kDNA era isolado segundo metodologia descrita por Pérez-Morgan e Englund, (1993). O protocolo começa com a centrifugação do meio LIT contendo formas epimastigotas a 1.500x g por 15 min, onde era obtido um sedimento com cerca de $5 \times 10^{7}$ formas de cultivo, e lavado duas vezes com PBS. O sedimento formado foi suspenso em $630 \mu \mathrm{L}$ de tampão NET-100 (10mM de Tris-HCl pH 8,0; 100mM de EDTA pH 8,0; $100 \mathrm{mM}$ de $\mathrm{NaCl}$ ). Para lisar as células, era adicionado $71 \mu \mathrm{L}$ de SDS $10 \%$ e $7 \mu \mathrm{L}$ de proteinase $\mathrm{K}(20 \mu \mathrm{g} / \mathrm{ml})$. Essa solução foi incubada a $37^{\circ} \mathrm{C}$ por 12 horas. Após a incubação, a solução foi homogeneizada com o auxílio de uma pipeta P1000, e foram acrescentados $690 \mu \mathrm{L}$ de tampão NET-100 com sacarose a $20 \%$. Essa solução foi então centrifugada a 14000 rpm por 15 minutos. O sobrenadante obtido foi removido com auxílio de uma pipeta. Novamente foi adicionado mais $690 \mu \mathrm{L}$ de NET-100 com sacarose $20 \%$, repetindo-se a centrifugação e a remoção do sobrenadante. Em seguida, o material genético foi ressuspenso em $1000 \mu \mathrm{L}$ de água destilada. Após, a solução obtida foi submetida a uma extração com clorofane e outra com clorofil. O material genético resultante, o kDNA, foi precipitado com 2,5 V de etanol $100 \%$ gelado e $0,1 \mathrm{~V}$ de acetato de sódio $3 \mathrm{M}, \mathrm{pH} 8,0$, lavado duas vezes com etanol 70\% gelado e ressuspenso em $200 \mu \mathrm{L}$ de tampão TE. Os tubos foram devidamente identificados e estocados em freezer a $-20^{\circ} \mathrm{C}$.

\subsubsection{Quantificação e teste de qualidade do DNA}

O material genético obtido da extração de DNA de células sanguíneas das aves foi quantificado em espectofotômetro NanoVue (GE). A concentração de cada amostra do tubo "estoque" foi documentada para posterior diluição em amostras de uso, com concentração de $200 \mathrm{ng} / \mu \mathrm{L}$. A integridade do DNA foi testada pelo teste PCR específico para o gene constitutivo de $\beta$-actina. 


\subsubsection{Reação em Cadeia da Polimerase (PCR)}

Para testar o DNA de cada ave quanto a presença de kDNA exógeno inserido foi realizada a reação em cadeia da polimerase de cada amostra de DNA extraído do sangue das aves. Para isso, as PCRs foram conduzidas com iniciadores (primers) específicos para kDNA de T. cruzi. Posteriormente, para confirmação, os fragmentos de kDNA amplificados (amplicons) de kDNA foram identificadas por hibridização com sonda específica de kDNA.

Para realizar o teste da Reação em Cadeia da Polimerase (PCR) e amplificar fragmentos de kDNA, utilizamos primers específicos para a região conservada de minicírculos de kDNA, denominados $\mathrm{S} 35$ e S36. Esses primers permitem a amplificação de duas regiões conservadas de kDNA com uma região variável inteira entre elas; essa reação amplifica fragmentos de tamanho aproximado de $330 \mathrm{pb}$ (Sturm et al., 1989). Todas as reações de amplificação foram realizadas em triplicata, e, além dos 200ng de DNA das amostras a serem analisadas, utilizou-se um controle branco (sem DNA), controle negativo (com 200ng de DNA de uma ave sem inoculação com o $T$. cruzi, denominada kDNA negativa ou kDNA-), controle positivo (com 200ng de DNA de uma ave kDNA positiva), e controle com 200ng de DNA total de T. cruzi.

Tabela 1. Sequência dos primers S35 e S36 kDNA de T. cruzi 5' ATAATG TAC GGG (T/G)GA GAT GC 3' 
A PCR foi realizada nas seguintes condições: tampão de reação 10X para PCR da Invitrogen ${ }^{\circledR}(20 \mathrm{mM}$ de Tris- $\mathrm{HCl} \mathrm{pH}$ 8.4, $50 \mathrm{mM}$ de $\mathrm{KCl}$ ); $2 \mathrm{mM}$ de $\mathrm{MgCl} 2 ; 0,2 \mu \mathrm{M}$ de cada primer, 0,2 mM de dNTPs e 2,5 unidades de Taq DNA polimerase $\left(\right.$ Invitrogen $\left.{ }^{\circledR}\right)$. A amplificação seguiu o seguinte programa:

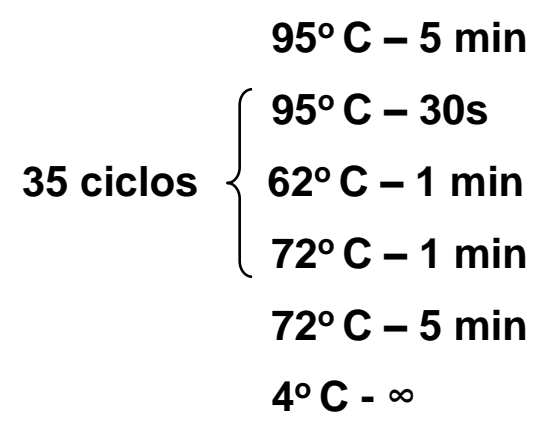

\subsubsection{Southern Blot}

O Southern Blot é um método que serve para transferir o DNA do gel de agarose para uma membrana de nylon que servirá para confirmar a presença de uma determinada sequência conhecida de DNA na amostra. Para realizar o Southern Blot das amostras, os amplicons, ou produtos resultantes das PCRs, foram submetidos à eletroforese em gel de agarose 1,5\% e corados com brometo de etídio $0,5 \mathrm{mg} / \mathrm{ml}$, utilizando-se tampão TAE 1X. A presença de DNA no gel foi observada em luz ultravioleta, e, caso confirmado sua presença, o DNA era transferido para membrana de nylon positivamente carregada, pela técnica de transferência alcalina por capilaridade (Sambrook e Russel, 2001). Conforme este protocolo, o gel resultante da eletroforese foi tratado com $\mathrm{NaOH} 0,4 \mathrm{M}$ por 20 min para promover a desnaturaçãodo DNA, separando-o em fita simples. Desta forma, por capilaridade, os amplicons migravam para a membrana de nylon positivamente carregada (HybondTM-N+, Amersham GE Healthcare ${ }^{\circledR}$ ). O processo de transferência ocorria durante 8 a 12 h. Após este tempo, as membranas contendo o DNA transferido foram secas em cabine biológica e submetidas à hibridização com sonda radioativa específica para kDNA. 


\subsubsection{Marcação de sondas radioativas}

Uma sonda de DNA de fita simples, marcada com um isótopo radioativo, visa a encontrar o trecho do DNA complementar e identificá-lo, posteriormente, com a exposição dessa sonda radioativa ao filme radiográfico. O 'kit' Random Primer Labelling System (Invitrogen ${ }^{\circledR}$ ) foi utilizado para marcar radioativamente fragmentos de kDNA do T. cruzi amplificados com os primers S35 e S36. Esse protocolo utiliza a enzima Klenow, primers randômicos, e um dATP radiomarcado [a-32P]. A enzima Klenow possui atividade semelhante a da enzima polimerase, dessa forma, quando a fita de DNA é sintetizada, são inseridos dATPs radiomarcados na sequência.

Seguindo o protocolo do fabricante, são usados na reação $30 \mathrm{ng}$ de DNA amplicons, produtos da PCR de kDNA, com volume final de $25 \mu \mathrm{L}$ completado com água Milli-Q. Estes fragmentos de kDNA são então desnaturados a $100{ }^{\circ} \mathrm{C}$ por 10 min e imediatamente incubados em gelo, sendo adicionados $2 \mu \mathrm{L}$ de dCTP, $2 \mu \mathrm{L}$ de dGTP, $2 \mu \mathrm{L}$ de dTTP, $15 \mu \mathrm{L}$ de tampão, $5 \mu \mathrm{L}$ de [a-32P] dATP $(3000 \mu \mathrm{Ci})$ e $1 \mu \mathrm{L}$ da enzima Klenow.

A reação ocorreu a temperatura ambiente por um período de aproximadamente três horas e foi finalizada com a adição de $5 \mu \mathrm{L}$ de tampão de parada.

\subsubsection{Purificação de sondas radioativas}

Para purificar as sondas radiomarcadas foram utilizadas Colunas de Sephadex G50 com lã de vidro, conforme protocolo descrito por Sambrook e Russel, (2001). nível de incorporação radioativa foi medida por cintilografia e as sondas produzidas respeitavam o limite de concentração de 1 a $2 \times 10^{6} \mathrm{cpm} / \mathrm{mL}$ de solução de hibridização. As atividades específicas exigidas foram iguais ou superiores a $10^{8} \mathrm{cpm} / \mu \mathrm{g}$ de DNA.

\subsubsection{Hibridização com sondas radioativas}

Neste estudo, a hibridização com sondas radioativas foi realizada para aumentar a sensibilidade do diagnóstico de presença de kDNA, ou seja, para comprovar que esses amplicons de 330pb eram realmente provenientes do kDNA de 
T. cruzi. Para realizarmos a hibridização do DNA, as membranas positivamente carregadas contendo o DNA transferido foram bloqueadas, ou seja, foram gentilmente fixadas na parede interna de cilindro de vidro, preenchido e tampado com $100 \mathrm{ml}$ de solução de pré-hibridização (PEG 800 10\%, SDS 7\%, SSPE 1,5\% e $100 \mu \mathrm{g} / \mathrm{ml}$ de DNA de esperma de salmão). Os cilindros foram acondicionados em forno de hibridização durante duas horas, com velocidade de rotação constante e com temperatura a $65^{\circ} \mathrm{C}$.

Aproximadamente 20 minutos antes de terminar o tempo das sondas no interior do forno, as sondas radioativas eram preparadas para adicionar à solução de préhibridização no interior do cilindro. Para isso, as sondas radiomarcadas foram submetidas a $100^{\circ} \mathrm{C}$ por 10 minutos para desnaturá-las. Em seguida, as sondas radiomarcadas, agora desnaturadas, eram adicionadas à solução de préhibridização e foi novamente mantida dentro do forno de hibridização, desta vez, por 12 horas a $65^{\circ} \mathrm{C}$. Para o próximo passo, a solução de hibridização era retirada completamente de dentro do cilindro para as membranas serem lavadas. As membranas eram lavadas quatro vezes: as duas primeiras lavagens eram realizadas a $65^{\circ} \mathrm{C}$ por 15 minutos com solução de SSC $2 X$ / 0,1\% SDS. As duas últimas eram realizadas também a $65^{\circ} \mathrm{C}$ durante 15 minutos, mas com solução de SSC $0,1 \mathrm{X} /$ $0,1 \%$ SDS. Para fazer essas lavagens, a membrana contendo o DNA e previamente submetidas à ação da sonda radioativa eram ajustadas dentro do mesmo cilindro de vidro, e mantido em movimento circulatório constante.

Todas estas etapas foram realizadas dentro de forno específico para hibridização, com temperatura e velocidade de rotação ajustável. Imediatamente após as lavagens, as membranas eram retiradas de dentro do tubo de vidro, revestidas com filme plástico de PVC, e fixadas em uma estrutura metálica, denominada cassete, próprio para exposição a filme sensível a raios $X$ (Kodak T$\left.M A T^{\circledR}\right)$.

Após, em uma câmara escura, um filme de raio-x era ajustado dentro do cassete juntamente com a membrana pré-fixada na outra lateral do cassete, para exposição à radiação das sondas. Os cassetes eram então identificados e acondicionados em ultrafreezer, a $-80^{\circ} \mathrm{C}$. $\mathrm{O}$ tempo de exposição do filme dentro do cassete era de três dias. A revelação dos filmes foi realizada em sala escura utilizando solução comercial de revelação e fixação $\left(\operatorname{Kodak}^{\circledR}\right)$. 


\subsection{Transplante de medula óssea}

Os animais F1, machos, com seis meses de idade, devidamente identificados com numeração individual, e previamente separados em grupos de cinco animais, foram selecionados para serem receptores de medula óssea.

Nesse experimento, as aves candidatas ao transplante de medula óssea foram submetidas à supressão prévia, 48 horas antesdo transplante. A ablação da medula óssea consistiu na administração sequencial de metotrexato - Fauldmetro ${ }^{\circledR} 10 \%$, 150 mg/kg, I.V., lentamente pela veia ulnar (Figura 7, A e B), e do bussulfano -

Myleran ${ }^{\circledR} 2 \mathrm{mg}, 7 \mathrm{mg} / \mathrm{kg}$, via oral, administrado através de sonda uretral $\mathrm{n}^{\circ} 8$ (Figura 7, C). Na dosagem administrada não houve reação adversa ou morte dos animais e era obtida a ablação da medula óssea nas aves. 

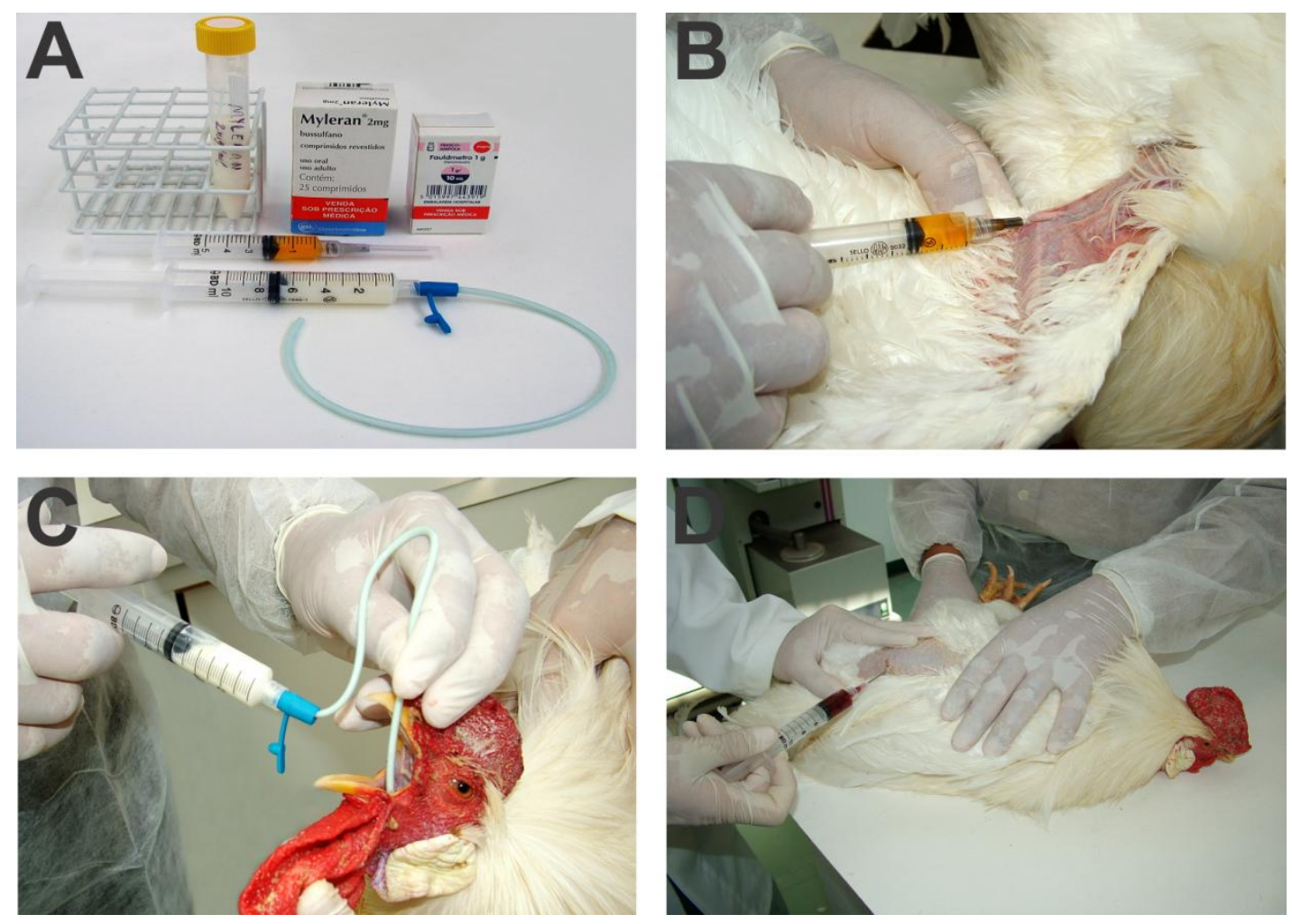

Figura 7. Tratamento para supressão e transplante da medula óssea. A) Quimioterápicos utilizados no tratamento para supressão medular nas aves; B) Administração de metotrexato; C) Administração de bussulfano; D) Punção de medula óssea da tíbia da ave doadora.

Após 48 horas do tratamento com as drogas citadas, as aves receberam o transplante de medula óssea, de acordo com o planejamento para cada grupo experimental. As aves doadoras ou receptoras de medula óssea foram contidas manualmente para retirada das penas na região sobre a articulação femoro-tíbiopatelar das aves e a assepsia da pele era feita com álcool iodado. Em seguida à aplicação da anestesia local $(0,1 \mathrm{~mL}$ de lidocaína a $2 \%)$, injetada no subcutâneo, logo acima da crista tibial. Dois minutos após, introduzia-se agulha 40×12 previamente molhada com heparina em ângulo de 90 graus com movimentos de rotação sobre a crista da tíbia, até adentrar no canal medular. O conteúdo intramedular era então puncionado com uso de uma seringa de $20 \mathrm{ml}$ (Figura 7, D). De cada ave era obtida aproximadamente $1,0 \mathrm{ml}$ de medula óssea, que fluía lentamente, e tinha aspecto de sangue aerado, viscoso e gorduroso. Logo em 
seguida, transplantava-se a medula óssea aspirada na ave receptora que tinha tido sua medula óssea previamente destruída pelas drogas metotrexato e bussulfano.

Nenhum dos animais submetidos ao protocolo experimental apresentou reação adversa de rejeição da medula óssea enxertada.

\subsubsection{Bussulfano}

O bussulfano é um medicamento quimioterápico, alquilante, citotóxico, que inibe a síntese do DNA provocando a morte das células. É comumente utilizado no tratamento de pacientes humanos com leucemia granulocítica crônica. O bussulfano possui um tempo de meia-vida entre 2,3 a 2,8 horas e a toxicidade é dosedependente comumente caracterizada pelo aparecimento de efeitos adversos como cistite hemorrágica, catarata, convulsão, mucosite e doença venoclusiva hepática (Dulley et al., 2004). O mecanismo de ação do efeito seletivo desse medicamento sobre a granulocitopoiese não é ainda elucidado, mas sabe-se que ele é bastante efetivo na redução de massa total dos granulócitos.

Nos humanos a superdosagem aguda com 0 bussulfano causa mielossupressão, e, como consequência, a pancitopenia.

\subsubsection{Metotrexato}

O metotrexato é um anti-metabólico, citostático, análogo do ácido fólico. A droga entra nas células por transporte ativo, pela mesma via utilizada por folatos reduzidos, onde inibe a enzima di-hidrofolato redutase e impede a replicação celular. Em humanos, o metotrexato apresenta eliminação total em oito a quinze horas. É utilizado no tratamento de algumas neoplasias como a leucemia linfocítica aguda, linfoma, câncer de mama, sarcoma ósseo, entre outras. Possui efeito supressor da medula óssea, inibindo a hematopoiese e promovendo a pancitopenia.

\subsection{Ecocardiografia}

A função miocárdica das aves foi avaliada clinicamente, visando a identificação de modificações na estrutura e função miocárdica, antes e após o transplante de 
medula óssea. Os exames ecocardiográficos foram realizados na mesma ocasião em todos os grupos experimentais. Antes do exame as aves eram mantidas em jejum de 4 horas. Uma semana antes do procedimento de transplante de medula óssea, as aves foram submetidas ao exame ecocardiográfico pré-tratamento. Esse exame foi realizado no Hospital Veterinário de Pequenos Animais da Universidade de Brasília, por um único operador especialista em ecocardiografia, o qual não tinha conhecimento dos grupos experimentais

Com o intuito de monitorar a evolução da cardiomiopatia chagásica, os animais foram submetidos a outros dois exames ecocardiográficos, aos 3 meses, e aos 10 meses pós-tratamento com transplante de medula óssea.

No dia da realização dos exames, os animais foram apanhados nos galinheiros, colocados em caixas de papelão, e transportados de carro até o Hospital Veterinário de Pequenos Animais da Universidade de Brasília, à distância de $2 \mathrm{~km}$. No hospital, as aves foram submetidas aos exames ecocardiográficos. Na sala de exame, cada ave foi contida pelas asas e pernas, com auxílio de um ajudante, e posicionadas em decúbito lateral direito sobre a mesa de procedimentos, com o transdutor posicionado no acesso paraesternal.

A função miocárdica global foi avaliada pelo exame ecocardiográfico no modo(B) bidimensional e modo $(M)$, com transdutor microconvexo de frequência $5 \mathrm{MHz}$, posicionado na porção ventromedial da ave como demonstra a Figura 8.

No exame ecocardiográfico foram avaliadas 8 variáveis:

1) SIVd: Espessura do septo interventricular em diástole;

2) SIVs: Espessura do septo interventricular em sístole;

3) DIVEd: Diâmetro interno do Ventrículo Esquerdo em diástole;

4) DIVEs: Diâmetro Interno do Ventrículo Esquerdo em sístole;

5) PLVEd: Espessura da Parede Livre do Ventrículo Esquerdo em diástole;

6) PLVEs: Espessura da Parede Livre do Ventrículo Esquerdo em sístole;

7) FS: Fração de Encurtamento do ventrículo esquerdo;

8) EF: Fração de Ejeção do ventrículo esquerdo. 
Para tal análise, a fração de ejeção (EF) e fração de encurtamento (FS) foram calculadas pelo método de Teichholz, a partir da janela paraesternal esquerda. Este método estima a fração de ejeção de sangue do ventrículo esquerdo a partir das medidas do diâmetro diastólico final e do diâmetro sistólico final do ventrículo esquerdo (Teichholz et al., 1976).

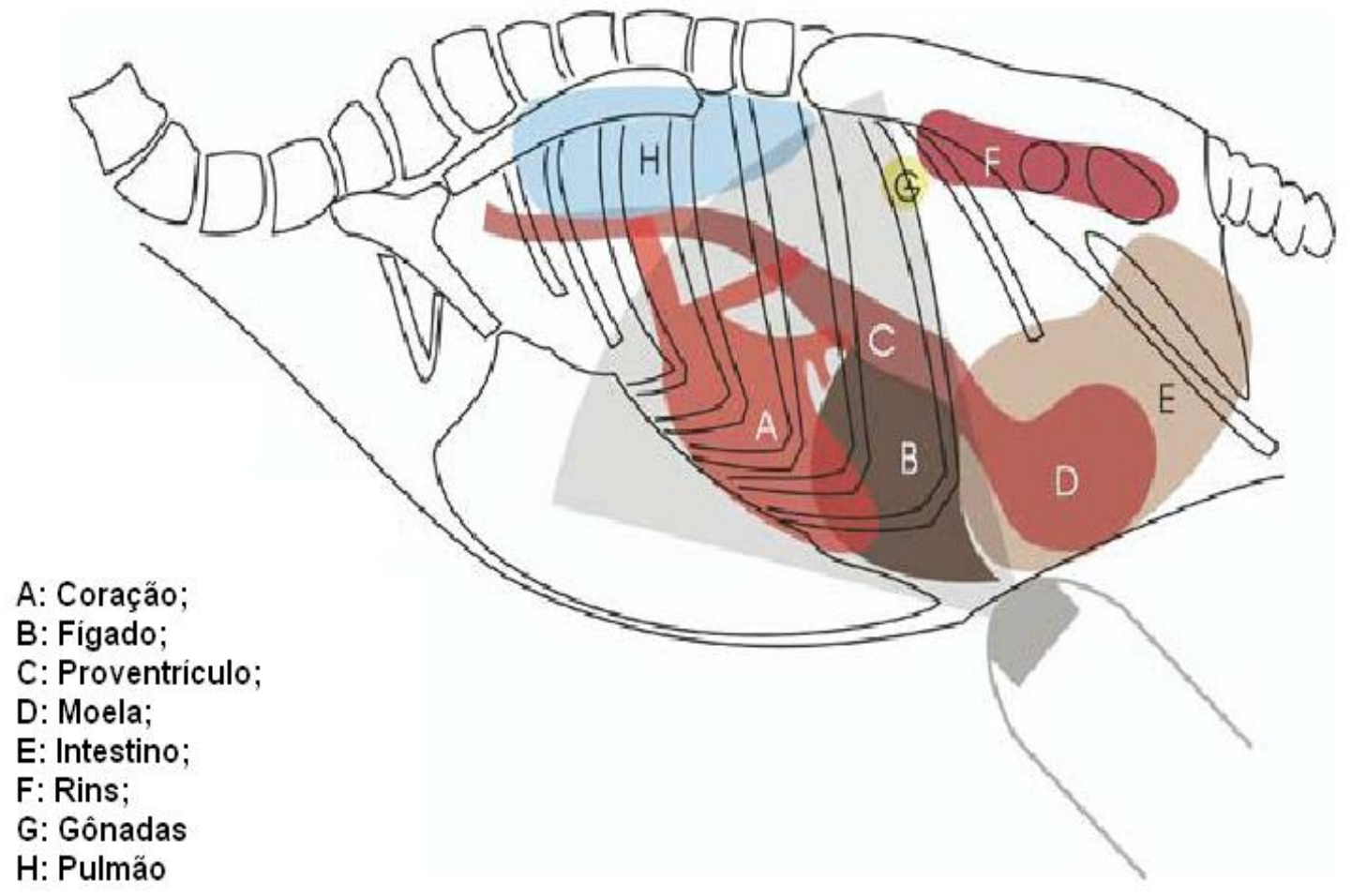

Figura 8. Visualização do coração da ave em decúbito lateral direito e posicionamento de probe na janela paraesternal.

Fonte: Pees e Krautwald-Junghanns (2005), com modificação.

\subsection{Análise Estatística}

Cada variável ecocardiográfica obtida foi comparada entre os grupos experimentais utilizando o teste não paramétrico de Kruskal-Wallis. As comparações entre os quatro grupos experimentais foram realizadas antes e após a intervenção. Além disso, as variáveis ecocardiogáficas das aves de um mesmo grupo antes e após o transplante de medula foram comparadas utilizando o teste não paramétrico de Wilcoxon. Em ambos os testes foi considerado um nível de significância de $p<0,05$. Os valores das variáveis ecocardiogáficas dos grupos experimentais foram 
apresentados por meio de gráficos box plot com medianas, percentis, valores mínimos e máximos. Todos os testes foram realizados no programa Statistica®. 


\section{Resultados}

\subsection{Modificação dos genomas das aves pela integração de sequências de minicírculos de kDNA de Trypanosoma cruzi}

Os testes de hibridização após Southern blot documentaram a integração de sequências de minicirculos de kDNA no genoma das aves. Neste teste, a presença de fragmentos de kDNA exógeno de aves nascidas de ovos inoculados com T. cruzi e das aves controle foram identificados com sonda de kDNA radiomarcado. Esta análise revelou a presença de banda de kDNA de 330pb apenas nas amostras colhidas das aves que foram nascidas de ovos inoculados com T. cruzi, mostrando que houve a integração do DNA exógeno no genoma dessas aves (Figura 9, A e B). Estudos anteriores (Teixeira et al., 2011b; Guimaro et al., 2014) demonstraram a partir de sequenciamento, que estes fragmentos de 330pb são originários de minicírculos de kDNA de Trypanosoma cruzi. A frequência de integração do kDNA no grupo das aves cujos embriões foram expostos com inoculação de 100 formas de tripomastigotas de T. cruzi no ovo, revela que $80 \%$ das aves nascidas dos ovos embrionados inoculados com 100 formas tripomastigotas de $T$. cruzi retiveram fragmentos de kDNA em seu genoma. 

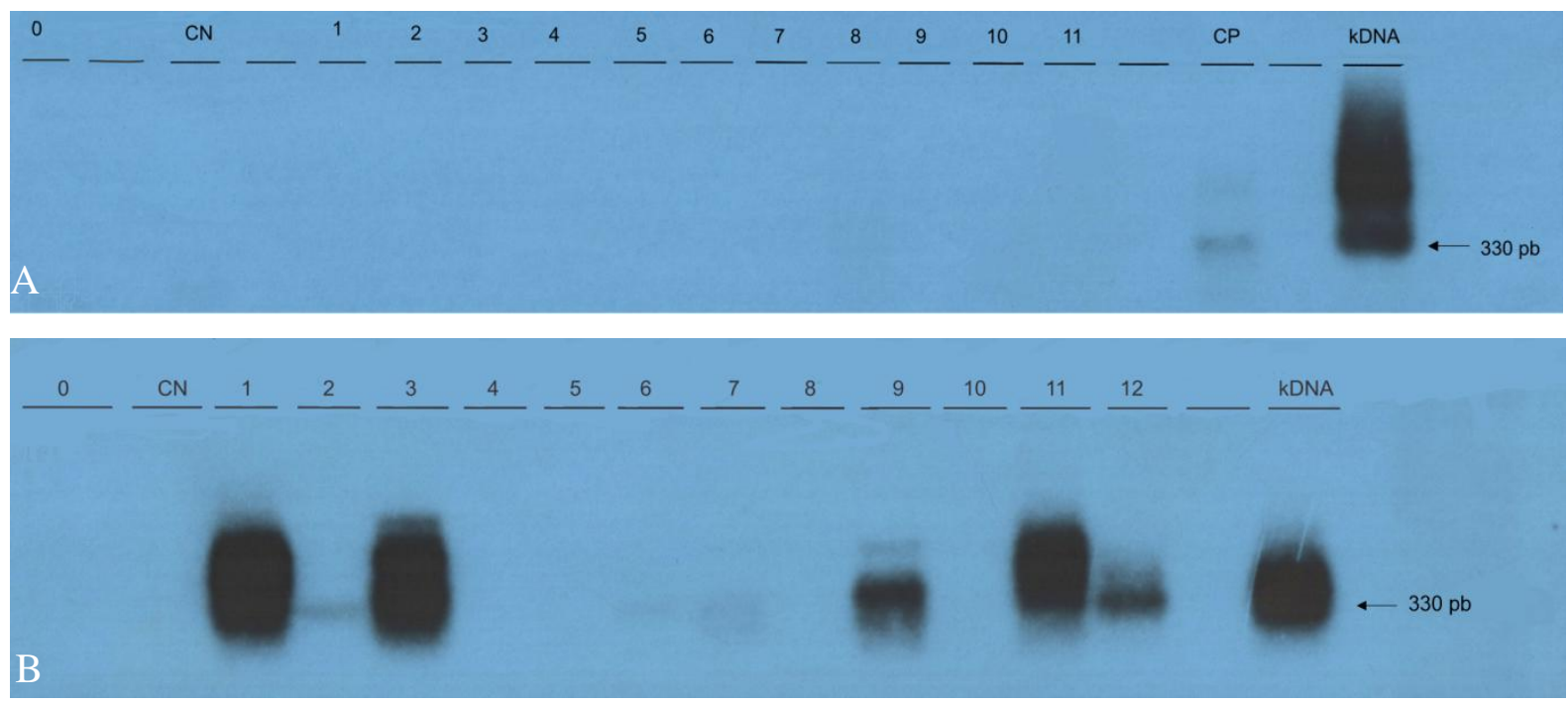

Figura 9. Filme radiográfico resultado de hibridização com sonda radioativa de kDNA de amostras de DNA de aves controle e amostras de DNA de aves oriundas de ovos inoculados com $T$. cruzi respectivamente $\mathrm{A}$ e B. A) Amostras oriundas de ovos embrionados controle, sem inoculação do $T$. cruzi. 0, amostra branco, sem DNA; CN, amostra de DNA de ave controle negativo (kDNA-); 1 a 11, amostras de aves controle, produtos de PCR com primer S35 e S36 seguido por hibridização com sonda radioativa; $\mathrm{CP}$, ave controle positivo, oriundo de DNA extraído de ave kDNA+; kDNA, amostra produto de PCR utilizando kDNA diretamente extraído de cultura de T. cruzi. B) Amostras de DNA de aves nascidas de ovos embrionados inoculados com T. cruzi. 0 amostra branco, sem DNA; CN, Controle Negativo; 1 a 12, amostras de DNA extraídas de aves nascidas de ovos inoculados com $T$. cruzi; kDNA, amostra de kDNA extraída diretamente de cultura de T. cruzi.

\subsection{Ecocardiografia}

Tendo modificado o genoma das aves de linhagem isogênica pela integração de sequências de minicírculos de kDNA do T. cruzi inoculado no ovo embrionado, deu-se continuidade ao estudo clínico que consistiu na observação das aves dos grupos controles (sadias, kDNA-) e teste ( $\mathrm{kDNA}+$ ) e do estudo ecocardiográfico. Cada um dos oito parâmetros ecocardiográficos analisados foi obtido pela mediana das aves que compõem cada grupo experimental. $O$ mesmo foi feito na segunda e terceira avaliações ecocardiográficas, três meses (T3) e 10 meses (T10) após o transplante de medula óssea, respectivamente (Apêndice 1).

Os grupos 1 e 2, controles, não sofreram alterações significativas de funcionamento cardíaco ao longo desses dez meses de análise. Das oito variáveis ecocardiográficas analisadas, seis (DIVEd, DIVEs, PLVEd, PLVEs, SIVd e SIVs) não apresentaram variação significativa entre os grupos experimentais. Ao comparar os quatro grupos antes do tratamento, observamos que não houve diferença significativa 
entre os parâmetros. Após o tratamento, apenas duas variáveis (fração de encurtamento e fração de ejeção) apresentaram diferenças significativas entre os grupos (Tabela 2).

Ao comparar as aves de um mesmo grupo antes e após o tratamento, foramobservadas diferenças significativas estatisticamente apenas para o grupo 4 de inibição da doença (Tabela 3). Nesse grupo houve diminuição da fração de encurtamento (FS) e fração de ejeção (EF) do ventrículo esquerdo (Figura 10A-B), e aumento do diâmetro interno do ventrículo esquerdo em sístole (DIVEs), após 10 meses da intervenção (Figura 11B).

Apesar disso, algumas tendências puderam ser observadas. Primeiro, analisando os resultados obtidos no grupo 3 (Figura 7, A-B), sugere-seque a transferência de medula óssea proveniente de ave com kDNA de T. cruzi (kDNA+) para outra não mutada (kDNA-) foi capaz de induzir a cardiopatia em algumas aves. As aves originalmente saudáveis que receberammedula óssea proveniente de aves kDNA+ apresentou substancial decréscimo da fração de ejeção $(E F)$ e também na fração de encurtamento (FS). Porém não foram observadas diferenças estatísticas significativas para afirmar que a transferência de medula óssea proveniente de ave com kDNA de T. cruzi (kDNA+) para outra não mutada (kDNA-) foi capaz de induzir a cardiopatia nas aves. O mesmo ocorreu ao analisar a variável DIVEs (Figura 11B). 
Tabela 2. Dados estatísticos resultantes das comparações entre os quatro grupos experimentais de acordo com as oito variáveis ecocardiográficas analisadas pelo teste de Kruskal-Wallis. Os valores em negrito indicam diferenças significativas considerando $p<0,05$.

\begin{tabular}{lrrrr}
\hline Variável $^{*}$ & $\begin{array}{l}\text { Antes do tratamento } \\
\text { Kruskal-Wallis }\end{array}$ & \multicolumn{2}{c}{$\begin{array}{c}10 \text { meses após tratamento } \\
\text { Kruskal-Wallis }\end{array}$} & \begin{tabular}{l} 
p-valor \\
\hline SIVd
\end{tabular} \\
SIVs & 6,296 & 0,098 & 3,564 & 0,313 \\
DIVEd & 4,259 & 0,235 & 5,183 & 0,159 \\
DIVEs & 0,896 & 0,826 & 1,702 & 0,636 \\
PLVEd & 1,263 & 0,738 & 4,799 & 0,187 \\
PLVEs & 3,875 & 0,275 & 0,175 & 0,982 \\
FS & 3,490 & 0,322 & 5,537 & 0,137 \\
EF & 2,611 & 0,456 & $\mathbf{8 , 6 2 3}$ & $\mathbf{0 , 0 3 5}$ \\
\hline
\end{tabular}

SIVd: Espessura do Septo interventricular em diástole; SIVs: Espessura do Septo interventricular em sístole; DIVEd: Diâmetro Interno do Ventrículo Esquerdo em diástole; DIVEs: Diâmetro Interno do Ventrículo Esquerdo em sístole; PLVEd: Espessura da Parede Livre do Ventrículo Esquerdo em diástole; PLVEs: Espessura da Parede Livre do Ventrículo Esquerdo em sístole; FS: Fração de Encurtamento; EF: Fração de Ejeção do ventrículo esquerdo. 

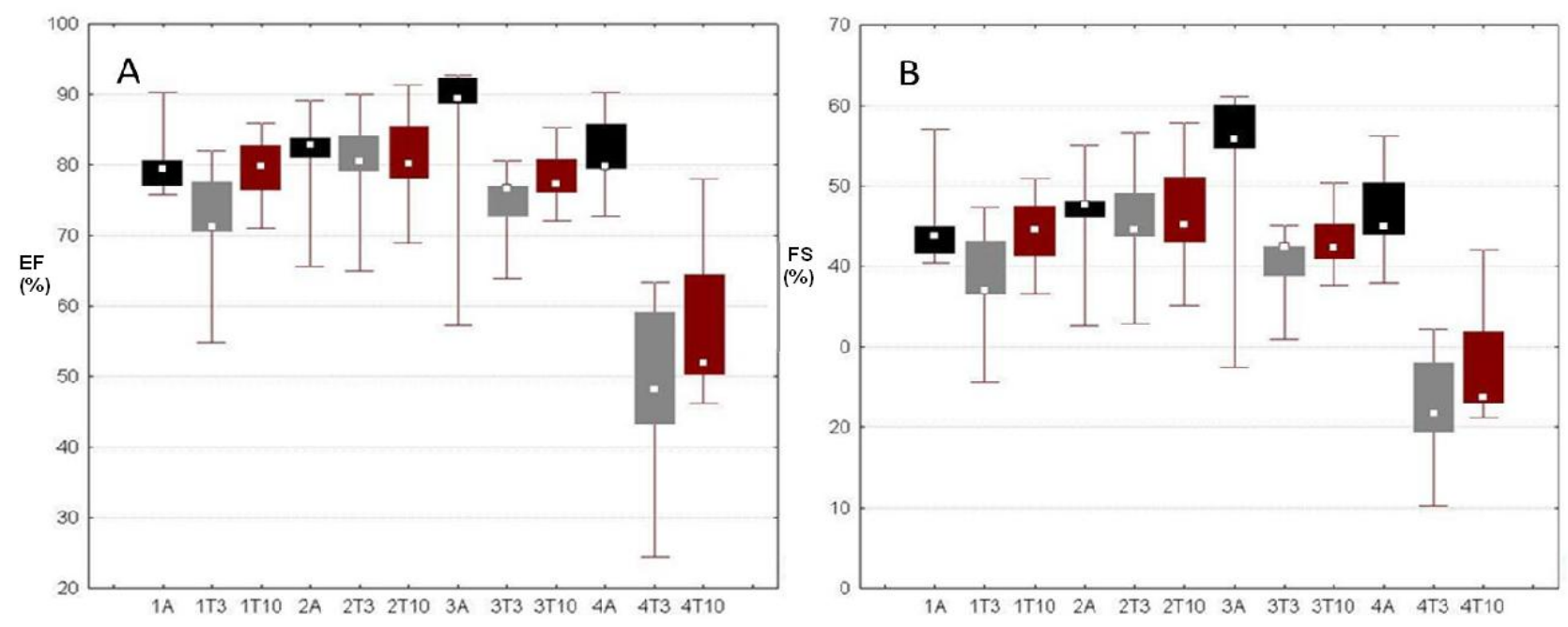

Figura 10. Gráficos em Box-plot demonstrando os valores das variáveis ecocardiográficas Fração de Ejeção do ventrículo esquerdo (EF) e Fração de Encurtamento (FS) do ventrículo esquerdo dos 4 grupos de aves (1: sem tratamento, 2: controle do tratamento, 3: indução da patologia, 4: inibição da patologia) em três momentos distintos: antes do transplante de medula, $A$, preto; três meses após o transplante de medula, T3, cinza; e dez meses após o transplante de medula óssea, T10, vermelho. Em cada gráfico são apresentadas as medianas (quadrado branco no centro de cada caixa), os percentis $25-75 \%$ (caixas) e valores máximos e mínimos (linhas). Legenda. A) Fração de Ejeção do ventrículo esquerdo (EF). B) Fração de Encurtamento do ventrículo esquerdo (FS). 

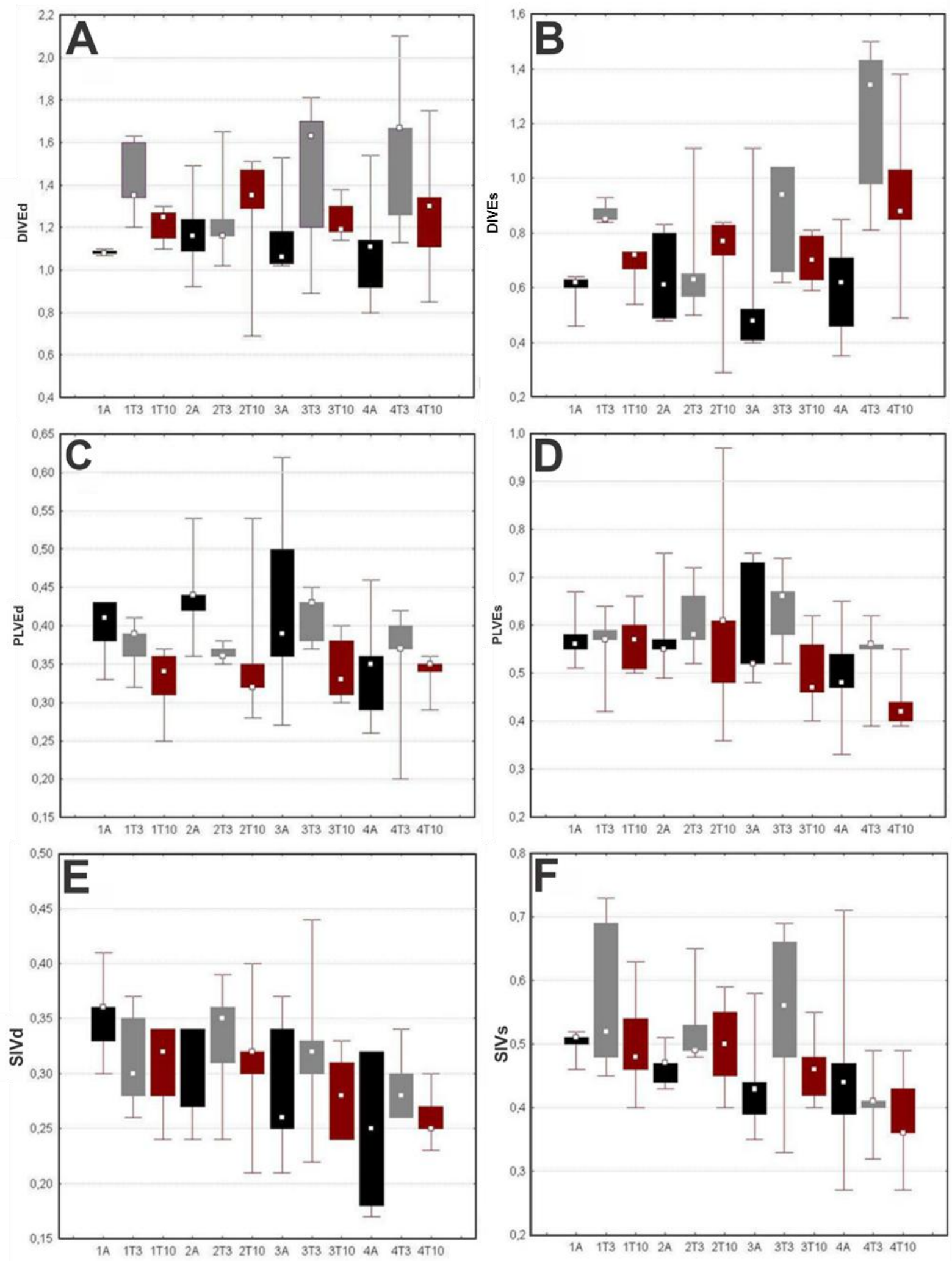

Figura 11. Gráficos em Box-plot demonstrando os valores em centímetros das variáveis ecocardiográficas dos 4 grupos de aves (1: sem tratamento, 2: controle do tratamento, 3: indução da patologia, 4: inibição da patologia) em três momentos distintos: antes do transplante de medula, $\mathrm{A}$, (preto); três meses após o transplante de medula, T3, (cinza); e dez meses após o transplante de medula, T10, (vermelho). Em cada gráfico são apresentadas as medianas, representadas por quadrado branco no 
centro de cada caixa, os percentís, que representam $75 \%$ das amostras, (caixas); e valores máximos e mínimos (linhas). A) Diâmetro Interno do Ventrículo Esquerdo em diástole (DIVEd). B) Diâmetro Interno do Ventrículo Esquerdo em sístole (DIVEs). C) Espessura da Parede Livre do Ventrículo Esquerdo em diástole (PLVEd). D) Espessura da Parede Livre do Ventrículo Esquerdo em sístole (PLVEs). E) Espessura do Septo Interventricular em diástole (SIVd). F) Espessura do Septo Interventricular em sístole (SIVs).

Tabela 3. Estatísticas resultantes das comparações entre aves de um mesmo grupo experimental antes e após o tratamento (grupos 2 a 4) de acordo com as oito variáveis ecocardiográficas analisadas pelo teste de Wilxocon. Os valores em negrito indicam diferenças significativas considerando $p<0,05$.

\begin{tabular}{lccc}
\hline Variável & Grupo & Wilcoxon & $p$ \\
\hline SIVd & 2 & 0,365 & 0,715 \\
& 3 & 0,135 & 0,893 \\
SIVs & 4 & 0,730 & 0,465 \\
& 2 & 1,214 & 0,225 \\
DIVEd & 3 & 1,753 & 0,080 \\
& 4 & 1,826 & 0,068 \\
DIVEs & 2 & 0,809 & 0,418 \\
& 3 & 1,079 & 0,281 \\
PLVEd & 4 & 1,753 & 0,080 \\
& 2 & 0,674 & 0,500 \\
PLVEs & 3 & 0,944 & 0,345 \\
& 4 & $\mathbf{2 , 0 2 3}$ & $\mathbf{0 , 0 4 3}$ \\
& 2 & 1,826 & 0,068 \\
FS & 3 & 1,214 & 0,225 \\
& 4 & 0,365 & 0,715 \\
& 2 & 0,135 & 0,893 \\
EF & 3 & 1,214 & 0,225 \\
& 4 & 0,674 & 0,500 \\
& 2 & 0,135 & 0,893 \\
& 3 & 1,214 & 0,225 \\
& 4 & $\mathbf{2 , 0 2 3}$ & $\mathbf{0 , 0 4 3}$ \\
& 2 & 0,135 & 0,893 \\
& 3 & 0,944 & 0,345 \\
& 4 & $\mathbf{2 , 0 2 3}$ & $\mathbf{0 , 0 4 3}$ \\
\hline
\end{tabular}

O grupo 4, ou o grupo das aves kDNA+ que receberam tratamento com transplante de medula óssea, apresentou piora clínica evidenciada pelo decréscimo da Fração de Ejeção (EF) e da Fração de Encurtamento (FS) nos três primeiros meses pós-tratamento (T3). Entretanto, na terceira e última análise da ecocardiografia (T10), os indivíduos desse grupo apresentaram uma tendência de melhora desses parâmetros (Figuras 10, A e B). O mesmo ocorreu com DIVEs, (Figura 11, B). 


\section{Discussão}

As aves congênicas de Praga são consideradas o melhor modelo animal geneticamente definido para estudos da patogenia da doença de Chagas na ausência do parasito, ou seja, sem infecção ativa com T. cruzi (Guimaro et al., 2014). Em cada uma das linhagens CB isogênicas empregadas neste estudo foram introduzidas modificações no genoma mediante a integração de kDNA do T. cruzi inoculado no ovo embrionado antes da incubação. As aves nascidas desses ovos embrionados e infectados tiveram as mutações de kDNA comprovadas pelos testes de PCR que amplifica banda de minicírculos de $330 \mathrm{pb}$. A ausência de bandas de nDNA de T. cruzi confirma que aves imunocompetentes são refratárias a infecção por T. cruzi. As sequências de kDNA integraram em vários cromossomos, e as quimeras estavam presentes em elementos repetitivos, principalmente em transposon CR1 (82\%) amplamente distribuído no genoma da ave (Teixeira et al., 2011b; Guimaro et al., 2014).

As linhagens de aves CB e CC que alcançaram a isogenicidade ao longo de várias décadas de reprodução por inseminação programada de aves irmãs, oriundas da variedade leghorn, foram empregadas nesses estudos devido ao reconhecimento da sua identidade genômica, pois numa mesma linhagem as aves são verdadeiras cópias idênticas. Por outro lado, há indicação de que a variedade leghorn possui menos possibilidade de adquirirem espontaneamente cardiopatia do que linhagens de frango de corte (broiler); segundo Martinez-Lemus et al., (1998), os frangos de corte possuem mais rápido desenvolvimento muscular, sem que haja o acompanhamento proporcional da estrutura cardíaca, e por isso possuem maior casuística de insuficiência cardíaca em animais adultos. Esses autores observaram a partir da ecocardiografia que a variedade broiler possui estruturas cardíacas de maior dimensão, comparativamente com a variedade leghorn.

As aves geneticamente modificadas pelas mutações de kDNA atingiram a maturidade sexual e foram submetidas a uma série de experimentos que demonstraram o papel central das modificações genômicas induzidas pela integração do kDNA do parasito na patogênese da miocardiopatia observada nas aves mutadas (Guimaro et al., 2014). Esses experimentos demonstraram a proliferação das células imunes que alcançaram os vasos sanguíneos e linfáticos e chegaram ao miocárdio das aves mu- 
tadas. As células imunes, em especial, os linfócitos CD-8, produziram a miocardite difusa em aves kDNA+. No conjunto, os resultados sugerem que o sistema imune das aves geneticamente modificadas pelas mutações passa por alterações cíclicas de rearranjos que explicam a evolução longa da doença, com fases de recrudescência e de silêncio com melhora clínica.

Trabalhos prévios do Laboratório Multidisciplinar de Pesquisa em Doença de Chagas, Faculdade de Medicina da Universidade de Brasília descreveram sobre vários aspectos da autoimunidade de origem genética em aves mutadas pelo kDNA do T. cruzi (Teixeira et al., 2011a; 2011b; 2012; Guimaro, et al., 2014) e a presente tese de doutorado é parte dessas investigações que foram feitas ao longo de mais de 14 anos de pesquisa multidisciplinar, representando verdadeiro esforço de construção coletiva do conhecimento.

De Wit e Schoemaker (2005) afirmaram que a ecocardiografia é a melhor ferramenta para o diagnóstico de cardiomiopatias nas espécies de aves. No presente trabalho das oito variáveis ecocardiográficas medidas três apresentaram variação significativa entre os grupos experimentais: fração de encurtamento, fração de ejeção do ventrículo esquerdo e diâmetro interno do ventrículo esquerdo em sístole. Segundo Sánchez-Montalvá et al., (2016), são perspectivas de mal prognóstico, pacientes com baixa Fração de Ejeção (<40\%), e diâmetro diastólico do ventrículo esquerdo aumentado; os autores afirmam que quando essas alterações cardíacas estão presentes, as lesões estarão amplamente difundidas pelo tecido cardíaco do paciente.

Nossos resultados demonstram que não houve melhora significativa da função miocárdica das aves contendo a mutação ou kDNA+ logo nos 3 primeiros meses após tratamento com células provenientes de medula óssea de aves saudáveis (aves do grupo 4). Pelo contrário, houve uma piora significativa da fração de ejeção, da fração de encurtamento e dodiâmetro interno do ventrículo esquerdo em sístole 3 meses após o transplante. Porém, os resultados apontam uma tendência de melhora da função do miocárdio na análise aos 10 meses pós-transplante, sugerindo que possa haver uma recuperação nessas aves tratadas com medula óssea sadia. Este fato pode ter ocorrido em decorrência da necessidade de maior tempo para as novas células de medula óssea sadia transplantada recolonizar a medula óssea da ave recipiente, até gerar e propagar novas células sadias no organismo das aves 
tratadas. Desta forma, enquanto as novas células de medula óssea estariam em processo de recolonização, a inflamação já estabelecida no coração kDNA+ estaria levando a progressão da patologia chagásica nestas aves, mesmo nos três primeiros meses pós-transplante. Além disso, o transplante de medula óssea foi realizado uma única vez em cada ave no presente trabalho.

Adicionalmente, os dados ecocardiográficos sugerem que as aves do grupo tratado (grupo 4) apresentaram menores valores de fração de ejeção (EF) e de fração de encurtamento (FS) indicando que essas aves já possuíam função miocárdica comprometida em decorrência das mutações de kDNA aos seis meses de idade, antes do transplante de medula óssea. Os resultados indicam que a cardiomiopatia das aves deste grupo foi de fato desenvolvida na ausência do parasito, ou infecção ativa. Porém, ao longo dos 10 meses de monitoramento ecocardiográfico o funcionamento do coração ficou agravado, quando comparado com os valores obtidos antes do transplante (T0) e 10 meses após (T10). Entretanto, ao analisarmos a diferença destes mesmos parâmetros (EF e FS) notamos que houve uma melhora da função miocárdica em ambos, quando comparados os resultados de 3 meses após o transplante (T3) e dez meses após (T10). Este resultado sugere que a recuperação da função miocárdica comprometida pela miocardite autoimune ocorre lentamente ao longo dos meses pós transplante de medula óssea.

Em outro estudo, que envolveu o transplante de medula óssea em camundongos na fase crônica da doença de Chagas, Soares et. al., (2004) injetaram medula óssea singênica via endovenosa 6 meses após inoculação dos animais com - T. cruzi e concluíram que os benefícios do tratamento apareceram dois a três meses após o transplante. Neste estudo, a equipe demonstrou que no grupo tratado houve uma significante diminuição de infiltrado inflamatório e de fibrose intersticial, características comuns no coração chagásico.

Em um estudo pioneiro, Villas-Boas et al., (2004) realizaram transplante de medula óssea autóloga intracoronariana em paciente portador de insuficiência cardíaca chagásica crônica. Após 30 dias do transplante, os autores constataram melhora significativa da fração de ejeção (EF) de $24 \%$ para $32 \%$ e diminuição do diâmetro do ventrículo esquerdo em diástole (DIVEd), de $82 \mathrm{~mm}$ para $76 \mathrm{~mm}$. 
Nossos resultados demonstram que as aves kDNA+ (grupo 4), tiveram aumento do diâmetro do ventrículo esquerdo, diminuição da fração de encurtamento, e menores índices de fração de ejeção de sangue do ventrículo esquerdo logo nos três meses subseqüentes ao transplante, com melhora discreta na avaliação ecocardiográfica de 10 meses. Esses resultados sugerem que o tratamento com células pluripotentes da medula óssea em aves com sintomatologia da cardiomiopatia autoimune pode ser efetiva na melhora clínica da função miocárdica mais tardiamente.

Nas últimas décadas a terapia celular tem se demonstrado promissora no tratamento de cardiomiopatias e surgiu como uma opção no tratamento de casos avançados de insuficiência cardíaca. Orlic et al., (2001) demonstraram que após a realização do transplante de células de medula óssea de camundongos infectados por T. cruzi, ocorria o reparo do miocárdio a partir da formação de novas fibras cardíacas e também da neoangiogênese no tecido infartado. Strauer et al., (2002) foram os primeiros a demonstrar a segurança da infusão intracoronariana de células tronco de medula óssea para o tratamento de pacientes com miocardiopatia isquêmica. Perin et al., (2003) demonstraram a transferência de células mononucleares de medula óssea autóloga diretamente no endocárdio de pacientes com insuficiência cardíaca isquêmica severa. Para isso, as células mononucleares eram instiladas via cateter dentro da câmara do ventrículo esquerdo, próxima a lesões isquêmicas, e resultou em angiogênese e diminuição das áreas isquêmicas.

Os resultados obtidos nos exames ecocardiográficos confirmaram a nossa hipótese de que as modificações genômicas produzem seus efeitos no aparecimento das manifestações clínicas, e sugerem a possibilidade de tratamento da miocardiopatia autoimune no modelo de aves singênicas.

Em estudo anterior, o transplante de medula óssea sadia em aves kDNA+ que tiveram a medula óssea destruída com metotrexato e bussulfano mostrou ausência de rejeição dos enxertos de coração, sem infiltrado inflamatório e patologia cardíaca nas aves adultas (Guimaro et al., 2014). No presente estudo, o transplante de células de medula óssea de ave kDNA+ doente em aves sadias, kDNA-, que tiveram a medula óssea destruída pelas drogas, produziram sinais clínicos de redução da Fração de Ejeção (EF) e de Fração de Encurtamento (FS) evidenciados no ecocardiograma, e sugerem o desenvolvimento da cardiomiopatia a partir do transplante de células tronco mesenquimais mutadas com o kDNA. 
A reconhecida refratariedade das aves ao $T$. cruzi foi conveniente ao estudo, já que neste modelo animal não há a necessidade de erradicar a infecção pelo parasito. Portanto, a inibição da doença autoimune do coração pela substituição de medula óssea doente (kDNA+) por medula óssea sadia (kDNA-) de ave singênica sugere a possibilidade de tratamento da miocardiopatia chagásica pelo transplante de medula óssea, porém são necessários experimentos com maior número de animais, com repetições de tratamentos de transplante em uma mesma ave e com mais tempo de acompanhamento para que seja avaliada a recuperação da função miocárdica pós-transplante. Após comprovação nesse modelo animal ainda há necessidade de experimentos em modelos experimentais não refratários ao $T$. cruzi, pois, para que o tratamento da doença de Chagas em humanos seja bem sucedido, existe a necessidade de uma nova droga para erradicação da infecção residual pelo T. cruzi. Finalmente, nós consideramos que o tratamento da miocardiopatia chagásica autoimune pode ser um objetivo alcançável ao médio e longo prazo. 


\section{Conclusões}

1. Foi comprovada a modificação dos genomas das aves experimentais pela integração de sequências de minicírculos de kDNA de T. cruzi.

2. As aves originalmente saudáveis que receberam medula óssea proveniente de aves mutadas (kDNA+) (grupo de indução da patologia) apresentou substancial decréscimo da fração de ejeção (EF) e também na fração de encurtamento (FS). Porém, não foram observadas diferenças estatísticas significativas para afirmar que a transferência de medula óssea proveniente de ave com kDNA de T. cruzi (kDNA+) para outra não mutada (kDNA-) foi capaz de induzir a cardiopatia.

3. Não houve melhora significativa dos principais parâmetros de função miocárdica (fração de ejeção, fração de encurtamento e diâmetro interno do ventrículo esquerdo em sístole) das aves mutadas $(\mathrm{kDNA}+)$ logo nos 3 primeiros meses após tratamento com células provenientes de medula óssea de aves saudáveis. Porém, foi observada uma tendência de melhora da função miocárdica na análise aos 10 meses pós-transplante, indicando uma possível recuperação de parâmetros da função miocárdica nessas aves tratadas com medula óssea sadia. 


\section{Referências bibliográficas}

ABAD-FRANCH, F.; DIOTAIUTI, L.; GURGEL-GONÇALVES, R.; GURTLER, R. Certifying the Interruption of Chagas Disease Transmission by Native Vectors: Cui Bono? Mem Inst Oswaldo Cruz. v.108(2), p.251-254, 2013.

ABDUCH, M.C.D.; ASSAD, R.S.; MATHIAS JR. W.; ABDUCH, V.D.A.; AIELO, V.D. A Ecocardiografia no Laboratório Cardiovascular: Um Guia para a Pesquisa com Animais. Arq Bras Cardiol. v.102(1), p.97-103, 2014.

ALVES, R.A. Tratamento Da Cardiopatia Autoimune de Aves Mutadas com o kDNA de Trypanosoma cruzi pela Transferência de Medula Óssea. Tese, Universidade de Brasília, 2013.

AMES, C. T.; QUAN, S. F.; RYCKMAN, R. E. Triatominae in Experimental Transmission of Plague. Am J Trop Med Hyg. v.3(5), p.890-896, 1954.

ANDERSSON, J. O. Gene Transfer and Diversification of Microbial Eukaryotes.Annual Reviews in Microbiology. v.63, p.177-193, 2009.

ANDRADE, J. A.; MARIN-NETO, J. A.; PAOLA, A. A. V.; VILAS-BOAS, F.; OLIVEIRA, G. M. M.; BACAL, F.; BOCCHI, E. A.; ALMEIDA, D. R.; FRAGATA, A. A.; MOREIRA, M. C. V.; XAVIER, S. S.; OLIVEIRA Jr, W. A.; DIAS, J. C. P. I Diretriz Latino Americana para o Diagnóstico e Tratamento da Cardiopatia Chagásica. Sociedade Brasileira de Cardiologia. Arq Bras Cardiol. v.97(2), p.1-48, 2011.

ARGAÑARAZ, E.R. Integração de Sequências de Minicírculo de kDNA de Trypanosoma cruziem Elemento L1 no Genoma da Célula Hospedeira. Tese, Universidade de Brasília, 1996.

AUFDERHEIDE, A.C.; SALO, W.; MADDEN, M.; STREITZ, J.; BUIKSTRA, J.; GUHL, F.; ARRIAZA, B.; RENIER, C.; WITTMERS, L.E.; FORNACIARI, G.J.; ALLISON, M. A 9000-year Record of Chagas Disease. Proc Natl Acad Sci U S A. v.101(7), p.2034-2039, 2003.

BAHN, P. G. ARCHAEOLOGY. 50.000-Years-Old Americans of Pedra Furada. Nature. v.362(6416), p.114-115, 1993.

BERN, C.; MONTGOMERY, S. P.; HERWALD, B.L. Evaluation and Treatment of Chagas Disease in the United States: a Systematic Review. JAMA. v.298, p. 2171-2181, 2007.

BERN, C. Antitrypanosomal Therapy for Chronic Chagas Disease. The New England Journal of Medicine. v.364, p.2527-2534, 2011.

BIOLO, A.; RIBEIRO, A.L.; CLAUSELL, N. Chagas Cardiomyopathy-Where do We Stand After a Hundred Years? Prog.Cardiovasc. Dis. v.52(4), p.300-316, 2010. 
BONNEY, K. M.; ENGMAN, D. M. Chagas Heart Disease Pathogenesis: One Mechanism or Many? Curr. Mol. Med. v.8(6), p.510-518, 2008.

BRASIL. Ministério da Saúde. Secretaria de Vigilância em Saúde. Departamento de Vigilância Epidemiológica. Doenças infecciosas e Parasitárias: Guia de Bolso. 8. ed. rev. - Brasília: Ministério da Saúde, 2010.

BROWN, J. R. Ancient Horizontal Gene Transfer. Nature - Genetics. v.4, p.121-132, 2003.

BURLEIGH, B.A. Probing Trypanosoma cruzi Biology with DNA Microarrays. Parasitology. v.128, p.3-10, 2004.

BURROWS, H; QUINN, J.P. The Collection of Spermatozoa From the Domestic Fowl and Turkey. Poultry Science, Amsterdam, v.16, p.19-24, 1937.

CHAGAS, C. New Human Trypanossomiasis.Morphology and Life Cycle of Schyzotrypanum cruzi, the Cause of a New Human Disease.Mem. Inst. Oswaldo Cruz. v.1, p.159-218, 1909.

CARVALHO, M.O. Análise Filogenômica de Transferência Horizontal em Genomas de Drosophila. Tese, Universidade Federal do Rio Grande do Sul, 2013.

CLARKE, D.L; JOHANSSON, C.; WILBERTZ, J.; VERESS, B.; NILSSON, E.; KALSTROM, H.; LENDAHL, U.; FRISÉN, J. Generalized Potential of Adult Neural Stem Cells. Science. v.288, p.1660-1663, 2000.

CORDEIRO, C, D. Identificação, Clonagem e Seqüenciamento de ProteínaQuinases na Saliva de Triatoma infestans. Dissertação, Universidade de Brasília, 2011.

COURA, J. R. Chagas Disease: What is Known and What is Needed - A Background Article. Mem.Inst. Oswaldo Cruz. v.102(1), p.113-122, 2007.

COURA, J. R.; BORGES-PEREIRA, J. Chagas Disease: 100 Years After its Discovery. A systemic Review. Acta Tropica. v.115(1-2), p.5-13, 2010.

COURA, J. R.; DIAS, J. C. P. Epidemiologia, Controle e Vigilância da Doença de Chagas - 100 anos Após sua Descoberta. Mem.Inst. Oswaldo Cruz. v.104(1), p.31-40, 2009.

DE WIT, M.; SCHOEMAKER, N. J. Clinical Approach to Avian Cardiac Disease.Seminars in Avian and Exotic Pet Medicine. v.14(1), p.6-13, 2005.

DIAS, E. Non-Receptivity of the Domestic Pigeon to the Schizotrypanum Infection. Mem. Inst. Oswaldo Cruz. v.40(2), p.191-193, 1944.

DIAS, J. C. P. Doença de Chagas e Transfusão de Sangue no Brasil: Vigilância e Desafios. Rev. bras. hematol. hemoter. v.28(2), p.81-87, 2006. 
DIAS, J. C. P.; SCHOFIELD, C. J. History of Chagas Disease as a Public Health Problem in Latin America. In: Chagas Disease, Bentham e-books, p.1-9, 2009.

DIAS, J. C. P.; PRATA, A.; CORREIA, D. Problems and Perpectives for Chagas Disease Control: in Search of a Realistic Analysis. Rev. Soc. Bras. Med. Trop. v.41(3), p.193-196, 2008.

DIAS, J. C. P.; NETO, V. A. Prevention Concerning the Different Alternative Routes for Transmission of Trypanosoma Cruzi in Brazil. Rev. Soc. Bras. Med. Trop. v. 44(2), p.68-72, 2011.

DIOTAIUTI, L. Triatomine-Vector of Trypanosoma cruzi Infection. Emerging Chagas Disease.TEIXEIRA, A. R.; VINAUD, M. C.; CASTRO, A. M. New York, NY: Bentham Science Publishers, 2009.

DULLEY, F. L.; VIGORITO, A. C.; STURARO, A. D.; RUIZ, M.A.; SABOYA, R.; MACEDO, M. C.M.; DA SILVA, R. L.; CHAMONE, D.A.; MEHTA, J.; BACIGALUPO, A.; DE SOUZA, C. A. Addition of Low-Dose Busulfan to Cyclophosphamide in Aplastic Anemia Patients Prior to Allogeneic Bone Marrow Transplantation to Reduce Rejection. Nature, Bone Marrow Transplantation. v.33, p.9-13, 2004.

DUNN, C. W.; RYAN, J. F. The Evolution of animal Genomes.Current Opinion in Genetics and Development. v. 35, p.25-32, 2015.

DUTRA, W. O.; MENEZES, C. A. S.; MAGALHÃES, L. M. D.; GOLLOB, K. J. Immunoregulatory Networks in Human Chagas Disease. Parasite Immunol. v.36(8), p.377-387, 2014.

FALCHETTO, E. B.; COSTA, S. C. S.; ROCHITTE, C. E. Diagnostic Challenges of Chagas Cardiomyopathy and CMR Imaging. Review.Global Heart. v.10(3), p.181187, 2015.

FERRARI, G.; CUSELLA, G.; ANGELLIS, D.; COLETTA, M.; PAOLUCCI, E.; STORNAIUOLO, A.; COSSU, G.; MAVILIO, F. Muscle Regeneration by Bone MarrowDerived Myogenic Progenitors. Science. v. 279(5356), p.1528-1530, 1998.

FIDALGO, L. M.; GILLE, L. Mitochondria and Trypanosomatids: Targets and Drugs.Pharmaceutical Research. v.28(11), p.2758-2770, 2011.

FONSECA-BERZAL, C.; IBANEZ-ESCRIBANO, A.; REVIRIEGO, F.; CUMELLA, J.; MORALES, P.; JAGEROVIC, N.; NOGAL-RUIZ, J.J.; ESCARIO, J. A.; SILVA, P. B.; SOEIRO, M.N.; GOMEZ-BARRIO, A.; ARAN, V. Antichagasic and Trichomonacidal Activity of 1-Substituted 2-Benzyl- 5-Nitroindazolin-3-Ones and 3-Alkoxy-2Benzyl-5-Nitro-2Hindazoles. Eur J Med Chem. v.115, p.295-310, 2016.

FUTUYMA, D. J. 2013. Evolution. 2nd ed. Sunderland, MA: Sinauer.

GADELHA, A. A. M.; VERÇOSA, A. F. A.; LORENA, V.M.B.; NAKAZAWA, M.; CARVALHO, A.B.; SOUZA, W. V.; FERREIRA, A. G. P.; SILVA, E. D.; KRIEGER, 
M. A.; GOLDENBERG, S.; GOMES, Y.M. Chagas' Disease Diagnosis: Comparative Analysis of Recombinant ELISA and the Haemaglutination Test. Vox Sanguinis. v.85, p.165-170, 2003.

GALVÃO, C., org. Vetores da doença de chagas no Brasil [online]. Curitiba: Sociedade Brasileira de Zoologia, 2014. 289p. Zoologia: Guias e Manuais de Identificação Series.

GALVÃO, C.; Gurgel-Gonçalves R. Vetores conhecidos no Brasil. In: Galvão, C. Vetores da Doença de Chagas no Brasil. Soc Bras Zoo. 2014; 88-170. Zoologia: Guias e Manuais de Identificação Series.

GAUNT, M. W.; YEO, M.; FRAME, I. A.; STOTHARD, J. R.; CARRASCO, H. J.; TAYLOR, M. C.; MENA, S. S.; VEAZEY, P.; MILES, G. A.; ACOSTA, N.; ARIAS, A. R.; MILES, M. A. Mechanism of Genetic Exchange in American trypanosomes. Nature. v.421(6926), p.936-939, 2003.

GOBBI, F.; ANGHEBEN, A.; ANSELMI, M.; POSTIGLIONE, C.; REPETTO, E.; BUONFRATE, D.; MAROCCO, S.; TAIS, S.; CHIAMPAN, A.; MAINARDI, P.; BISOFFI, Z. Profile of Trypanosoma cruzi Infection in a Tropical Medicine Reference Center, Northern Italy. Plos Neglected Diseases. v.8(12), p.1-6, 2014.

GOLDENFELD, N.; WOESE, C. Biology's Next Revolution.Nature. v.445, 2007.

GOMES, C. C. Lesões Típicas da Doença de Chagas em Aves com Genoma Alterado por Integração de Sequências de Minicírculos de kDNA de Trypanosoma cruzi. Tese, Universidade de Brasília, 2006.

GUARITA-SOUZA, L.C.; CARVALHO, K.A.T.; WOITOWICZ, V.; REBELATTO, C.; SENEGAGLIA, A.; HANSEN, P.; MIYAGUE, N.; FRANCISCO, J.C.; OLANDOSKI, M.; FARIA-NETO, J.R.; BROFMAN, P.; Simultaneous Autologous Transplantation of Cocultured Mesenchymal Stem Cells and Skeletal Myoblasts Improves Ventricular Function in a Murine Model of Chagas Disease. Circulation. v.114(1), p.120-124, 2006.

GUIMARO, M. C.; ALVES, R. M.; ROSE, E.; SOUSA, A. O.; ROSA, A. C.; HECHT, M. M.; SOUSA, M. V.; ANDRADE, R. R.; VITAL, T.; PLACHY, J.; NITZ, N.; HEJNAR, J.; GOMES, C. C.; TEIXEIRA, A. R. L. Inhibition of Autoimune Chagas-Like Heart Disease by Bone Marrow Transplantation. Plos Neglected Diseases. v.8(12), 2014.

GULH, F.; PINTO, N.; AGUILERA, G. Sylvatic Triatominae: a New Challenge in Vector Control Transmission. Mem. Inst. Oswaldo Cruz, v.104(I), p.71-75, 2009.

GURGEL-GONÇALVES, R. Filogeografia, Morfometria e Distribuição Geográfica Potencial de Populações de Rhodnius neglectus (Hemiptera, Reduviidae) no Brasil. Tese, Universidade de Brasília, 2008. 
GURGEL-GONÇALVES, R.; GALVÃO, C.; COSTA, J.; PETERSON, T. Geographic Distribution of Chagas Disease Vectors in Brazil Based on Ecological Niche Modeling.J Trop Med. v.2012, p.1-15, 2012.

GUTIERREZ, F. R.; GUEDES, P. M.; GAZZINELLI, R. T.; SILVA, J. S.The Role of Parasite Persistence in Pathogenesis of Chagas Heart Disease.Parasite Immunol. v.31(11), p.673-685, 2009.

HECHT, M. M.; NITZ, N.; ARAÚJO, P. F.; SOUSA, A. O.; ROSA, A. C.; GOMES, D. A.; LEONARDECZ, E.; TEIXEIRA, A. R. L. Inheritance of DNA Transferred from American Trypanosomes to Human Hosts. PLoS One. v.5(2), e.9181, p.1-16, 2010.

IMAI, K.; MAEDA, T.; SAYAMA, Y.; OSA, M.; MIKITA, K.; KURANE, I.; MIYAHIRA, Y.; KAWANA, A.; MIURA, S. Chronic Chagas Disease With Advanced Cardiac Complications in Japan: Case Report and Literature Review. Parasitology International. v.64, p.240-242, 2015.

JANSEN, A. M.; XAVIER, S. C. C.; ROQUE, A. L. R.The Multiple and Complex and Changeable Scenarios of the Trypanosoma cruzi Transmission Cycle in the Sylvatic Environment.Acta Tropica. v.151, p.1-15, 2015.

JUNQUEIRA, A, C, V.; DEGRAVE, W.; BRANDÃO, A. Minicircle Organization and Diversity in Trypanosoma cruziPopulations. Trends in Parasitology. v.21(6), p.270272, 2005.

KEELING, P. J.; PALMER, J. D. Horizontal Gene Transfer in Eukaryotic Evolution. Nature Reviews, Genetics. v.9, p.605-618, 2008.

KIERSZENBAUM, F.; IVANYI, J.; BUDZKO, D. B. Mechanisms of Natural Resistance to Trypanosomal Infection. Role of Complement in Avian Resistance to Trypanosoma cruzi Infection.Immunology. v.30, p.1-6, 1976.

KLINGBEIL, M. M.; ENGLUND, P. T. Closing the Gaps in Kinetoplast DNA Network Replication. v. 101(13), p.4333-4334, 2004.

Krampera M, Glennie S, Dyson J, Scott D, Laylor R, Simpson E, Dazzi F. Bone Marrow Mesenchymal Stem Cells Inhibit the Response of Naïve and Memory Antigen-Specific T Cells to Their Cognate Peptide.Blood. v.101, p.3722-3729, 2003.

KURLAND, C. G.; CANBACK, B.; BERG, O. G. Horizontal Gene Transfer: a Critical View. Proc Natl Acad Sci U.S.A. v.100(17), p. 9658-9662, 2003.

LAGUENS, R.P.; CARBEZA-MECKERT, P.M. \& VIGLIANO, C.A. Patogenia de la Miocarditis Chagasica Crônica Humana. Medicina, Buenos Aires, 59(2), p.3-68, 1999.

LAURIA-PIRES, I.; BRAGA, M.S.; VEXENAT, A.C.; NITZ, N.; SIMÕES-BARBOSA, A.; TINOCO, D.L.; TEIXEIRA, A.R.L. Progressive Chronic Chagas Heart Disease 
Ten Years After Treatment With Anti-Trypanosoma Cruzi Nitroderivatives. Am. J. Trop. Med. Hyg. v.63(3), p.111-118, 2010.

LIBBY, P.; BONOW, R. O.; MANN, D. L.; ZIPES, D. P. Braunwald, Tratado de Doenças Cardiovasculares. 8 ed. Elsevier, Rio de Janeiro. p.2183, 2008.

LIMA, L.; ESPINOSA-ÁlVAREZ, O.; TREIO-VARÓN, J. A.; CARRANZA, J. C.; PINTO, C. M.; SERRANO, M. G.; BUCK, G. A.; CAMARGO, E. P.; TEIXEIRA, M. M. Genetic Diversity of Trypanosoma cruzi in Bats, and Multilocus Phylogenetic and Phylogeographical Analyses Supporting Tcbat as an Independent DTU (Discrete Typing Unit). Acta trop. v.151, p.166-177, 2015.

LIMA, M. M.; SARQUISA, O.; OLIVEIRA, T. G.; GOMESA, T. F.; COUTINHO, C.; DAFLON-TEIXEIRA, N. F.; TOMAB, H. K.; BRITTO, C.; TEIXEIRA, B. R.; D'ANDREAD, P. S.; JANSENE, A. M.; BÓIAD, M. N.; CARVALHO-COSTAF, F. A. Investigation of Chagas Disease in Four Periurban Areas in Northeastern Brazil: Epidemiologic Survey in Man, Vectors, Non-human Hosts and Reservoirs. Trans R Soc Trop Med Hyg. v.106, p.143-149, 2012.

LIMA, C. T. O.; MARTINEZ, E. F.; FRANKEN, J. L.; JACOB, W. A.; OLIVEIRA Jr.; ORTIZ, J.; MORCEF, F. A.; MACHADO, F. S.; CASTILLO, J. M.; ANDRADE, J. L.; Consenso SOCESP-SBC sobre Ecocardiografia; Anatomia Patológica da Doença de Chagas Humana. Arq Bras Cardiol. v.65(5),1995.

LIU, B.; LIU, Y.; MOTYKA, S. A.; AGBO, E. E. C.; ENGLUND, P. T. Fellowship of the Rings: the Replication of kinetoplast DNA. Trends on Parasitology. v.21(8), p.363369, 2005.

LOPES, E. R.; CHAPADEIRO E. Anatomia Patológica da Doença de Chagas Humana. [online]. Rio de Janeiro: Editora FIOCRUZ, 1997. 486 p.

MARTIN, W.; BORST, P. Secondary loss of chloroplasts in Trypanosomes.Proceedings of the National Academy of Sciences of the United States of America. v.100(3), p.765-767, 2003.

MARTINEZ-LEMUS, L. A.; MILLER, M. W.; JEFFREY, J. S.; ODOM, T. W. Echocardiographic Evaluation of Cardiac Structure and Function in Broiler and Leghorn Chickens. Poultry Science, v.77, p.1045-1050, 1998.

MARTINS-MELO, F.R.; RAMOS Jr. A. N.; ALENCAR, C.H.; HEUKELBACH, J. Prevalence of Chagas disease in Brazil: a Systematic Review and Meta-Analysis. Acta Trop. v.130, p.167-174, 2014.

MIRANDA, C. G.; SOLANA, M. E.; CURTO, M. L.; SCHIJMAN, A. G.; ALBA, S. C. D. A Flow Cytometer-based Method to Simultaneously Assess Activity and Selectivity of Compounds Against the Intracellular Forms of Trypanosoma cruzi. Acta Trop. v.152, p.8-16, 2015.

MORILLO, C. A.; MARIN-NETO, J. A.; AVEZUM, A.; SOSA-ESTANI, S.; RASSI Jr., A.; ROSAS, F.; VILLENA, E.; QUIROZ, R.; BONILLA, R.; Britto, C.; GUHL, F.; 
VELAZQUEZ, E.; BONILLA, L.; MEEKS, B.; RAO-MELACINI, P.; POGUE, J.; MATTOS, A.; LAZDINS, J.; RASSI, A.; CONNOLLY, S. J.; S. YUSUF, S. Randomized Trial of Benznidazole for Chronic Chagas' Cardiomyopathy. The New England Journal of Medicine. v.373, p.1295-1306, 2015.

NEGRETE, O.A.; MORA, M.C.; BASOMBRÍO, M.A. High Prevalence of Congenital Trypanossoma cruzi Infection and Family Clustering in Salta, Argentina.Pediatrics. v.115(6), p.668-672, 2005.

NERY-GUIMARÃES, F.; LAGE, H. A. A Refratariedade das Aves ao Trypanosoma (Schizotrypanum) cruzi. Refratariedade das Galinhas Desde o Nascimento; Persistência da Refratariedade Após Bursectomia; Infecções em Ovos Embrionados. Mem. Inst. Oswaldo Cruz. v.70(1), p.97-107, 1972.

NEVES, D. P.; DE CASTRO, A. M. Behaviour of Trypanosoma cruzi in Various Species of Lizards. Revista Brasileira de Biologia, v.30(1), p.111-114, 1970.

NITZ, N.; GOMES, C.; ROSA, A. C.; D' SOUSA-AULT, M. R.; MORENO, F.; LAURAPIRES, L.; NASCIMENTO, R. J.; TEIXEIRA, A. R. L. Heritable Integration of kDNA Minicircle Sequences From Trypanosoma cruzi Into the Avian Genome: Insights Into Human Chagas Disease. Cell. v.118, p.175-186, 2004.

NUNES, M. C. P.; DONES, W.; MORILLO, C. A.; ENCINA, J. J.; RIBEIRO, A. L. Chagas Disease. An Overview of Clinical and Epidemiological Aspects. J Am Coll Cardiol. v.62(9), p.767-776, 2013.

OLIVARES-VILLAGÓMEZ, D.; MCCURLEY, T. L.; VNENCAK-JONES, C. L.; CORREA-OLIVEIRA, R.; COLLEY, D. G.; CARTER, C. E. Polymerase Chain Reaction Amplification of Three Different Trypanosoma Cruzi DNA Sequences From Human Chagasic Cardiac Tissue. Am. J. Trop. Med. Hyg. v.59(4), p. 563570, 1998.

OLIVEIRA, M. F.; NAGAO-DIAS, A. T.; PONTES, V. M. O.; SOUSA Jr., A. S.; COELHO, H. L. L.; COELHO, I. C. B. Tratamento Etiológico da Doença de Chagas no Brasil. Revista de Patologia Tropical. v.3(3), p.209-228, 2008.

ORLIC, D.; KAJSTURA, J.; CHIMENTI, S.; JAKONIUK, I.; ANDERSON, S.M.; LI, B.; PICKEL, J.; McKAY, R.; NADAL-GINARD, B.; BODINE, D.M.; LERI, A.; ANVERSA, P. Bone Marrow Cells Regenerate Infarcted Myocardium. Nature. v.410, p.701-705, 2001.

OSteRMAYER, A. L.; PASSOS, A. D. C.; SILVEIRA, A. C.; FERREIRA, A. W.; MACEDO, V.; PRATA, A. R. The National Survey of Seroprevalence for Evaluation of the Control of Chagas Disease in Brazil (2001-2008). Rev. Soc. Bras. Med. Trop. v.44(2). p.108-121, 2011.

PEES, M.; KRAUTWALD-JUNGHANNS, M. E. Seminars in Avian and Exotic Pet Medicine. v.14(1), p.14-21, 2005. 
PÉREZ-MORGA, D.; ENGLUND, P. T.The Structure of Replicating Kinetoplast DNA Networks.J. Cell Biol. v.123(5), p.1069-1079, 1993.

PERIN, E. C.; DOHMANN, H. F. R.; BOROEVIC, R.; SILVA, S. A.; SOUSA, A. L. S.; MESQUITA, C. T.; ROSSI, M. I. D.; CARVALHO, A. C.; DUTRA, H. S.; DOHMANN, H. J. F.; SILVA, G. V.; BELÉM, L.; VIVACQUA, R.; RANGEL, F. O. D.; ESPORCATTE, R.; GENG, Y. J.; VAUGHN, W. K.; ASSAD, M. D.; MESQUITA, E. T.; WILLERSON, J. T. Transendocardial, Autologous Bone Marrow Cell Transplantation for Severe, Chronic Ischemic Heart Failure. Circulation. v.107(18), p.2294-2302, 2003.

PONTES, V.M.O.; JÚNIOR, A.S.S.; CRUZ, F.M.T.; COELHO, H.L.L.; DIAS, A.T.N.; COÊLHO, I. C. B.; OLIVEIRA, M. F. Reações Adversas em Pacientes com Doença de Chagas Tratados com Benzonidazol, no Estado do Ceará. Revista da Sociedade Brasileira de Medicina Tropical. v.43(2), p.182-187, 2010.

RASSI, A. JR.; RASSI, A.; MARIN-NETO, J.A. Chagas Disease. The Lancet. v.375, p.1388-1402, 2010.

RASSI, A. JR.; RASSI, A.; REZENDE, J. M. American Trypanosomiasis (Chagas Disease). Infect. Dis. Clin. N. Am. v.26(2), p.275-291, 2012.

RIBEIRO DOS SANTOS, R. R.; ROSSI, M.; LAUS, J. L.; SILVA, J. S.; SAVINO, W.; MENGEL, J. Anti-CD4 Abrogates Rejection and Reestablishes Long-Term Tolerance to Syngeneic Newborn Heartys Grafted in Mice Chronically Infected with Trypanosoma cruzi. Am. J. Trop. Med. Hyg. v.50, p.261-268, 1992.

RIBEIRO, M.; NITZ, N.; SANTANA, C.; MORAES, A.; HAGSTROM, L.; ANDRADE, R.; RIOS, A.; SOUSA, A.; DALLAGO, B.; GURGEL-GONÇALVES, R.; HECHT, M. Sexual Transmission of Trypanosoma cruzi in Murine Model. Experimental Parasitology. v.162, p.1-6, 2016.

RODRIGUEZ-MORALES, A. J. Chagas Disease: an Emerging Food-Borne Entity? Journal of Infection in Developing Countries. v.2(2), p.149-150, 2008.

ROQUE, A. L. R.; JANSEN, A. M. Reservatórios do Trypanosoma cruzi e sua Relação com os Vetores. In: GALVÃO, C., org. Vetores da Doença de Chagas no Brasil [online]. Zoologia: Guias e Manuais de Identificação Series. Curitiba: Sociedade Brasileira de Zoologia, p.75-87, 2014.

SALGADO, J. A. O Centenário de Carlos Chagas e a Menina Berenice. Mem. Inst. Oswaldo Cruz. v.75(1-2), p.193-195, 1980.

SANCHEZ-MONTALVÁ, A.; SALVADOR, F.; RODRÍGUEZ-PALOMARES, J.; SULLEIRO, E.; SAO-AVILÉS, A.; ROURE, S.; VALERIO, L.; EVANGELISTA, A.; MOLINA, I. Chagas Cardiomyopathy: Usefulness of EKG and Echocardiogram in a Non-Endemic Country. PlosOne. v.11(6), p.1-13, 2016. 
SANTOS-BUCH, C. A.; TEIXEIRA, A. R. The Immunology of Experimental Chagas' Disease. Rejection of Allogeneic Heart Cells in vitro. The Journal of Experimental Medicine. v.140(1), p.38-53, 1974.

SARQUIS, O.; SPOSINA, R.; OLIVEIRA, T. G.; CORD, J. R. M.; CABELLO, P. H.; BORGES-PEREIRA, J.; LIMA, M. M. Aspects of Peridomiciliary Ecotopes in Rural Areas of Northeastern Brazil Associated to Triatomine (Hemiptera, Reduviidae) Infestation, Vectors of Chagas Disease. Mem. Inst. Oswaldo Cruz. v.101(2), p.143-147, 2006.

SBC- SOCIEDADE BRASILEIRA DE CARDIOLOGIA. I Diretriz Latino-Americana para o Diagnóstico e Tratamento da Cardiopatia Chagásica. Arquivos Brasileiros de Cardiologia. v.97(2), Supl. 3, Agosto 2011.

SCHMUNIS, G. A. Epidemiology of Chagas Disease in Non-Endemic Countries: the Role of International Migration. Mem.Inst. Oswaldo Cruz. v.102(1), p.75-85, 2007.

SCHOFIELD, C. J.; GALVAO, C. Classification, Evolution, and species groups within the Triatominae. Acta Trop. v.110(2-3), p.88-100, 2009.

SHAPIRO, T.A.; ENGLUND, P.T. The Structure and Replication of Kinetoplast DNA.Annual Reviews in Microbiology. v.49, p.117-143, 1995.

SHIKANAI-YASUDA, M. A.; CARVALHO, N. B. Oral Transmission of Chagas Disease.Clin. Infect. Dis. v.54, p.845-852, 2012.

SILVEIRA, A. C.; DIAS, J. C. P. The Control of Vectorial Transmission.Rev Soc Bras Med Trop, v. 44(2), p.52-63, 2011.

SIMÕES-BARBOSA, A. M.; BARROS, A. M.; NITZ, N.; ARGAÑARAZ, E. R.; TEIXEIRA,A. R. L. Integration of Trypanosoma cruzi kDNA Minicircle Sequence in the Host Genome May Be Associated with Autoimmune Serum Factors in Chagas Disease Patients. Mem. Inst. Oswaldo Cruz, v.94(1), p.249-252, 1999.

SIMÕES-BARBOSA, A. M. Transferência Horizontal de Sequência de Minicírculo de kDNA de Trypanosoma cruzi para Transposon LINE-1 e Alteração da Expressão do Gene p9 na Célula Hospedeira. Tese, Universidade de Brasília, 2000.

SIMONTI, C. N.; CAPRA, J. A. The Evolution of the Human Genome.Current Opinions in Genetics and Development. v.35, p.9-15, 2015.

SOARES, M.B.P.; RIBEIRO DOS SANTOS, R. Immunopathology of Cardiomyophaty in Experimental Chagas Disease. Mem. Inst. Oswaldo Cruz, Rio de Janeiro, 94(1), p.257-262, 1999.

SOARES, M. B. P.; LIMA, R. S.; ROCHA, L.L.; TAKYIA, C.M.; PONTES DE CARVALHO, L.; CARVALHO, A.C.C.; RIBEIRO DOS SANTOS, R. Transplanted Bone Marrow Cells Repair Heart Tissue and Reduce Myocarditis in Chronic Chagasic Mice. The American Journal of Pathology. v.164(2), p.441-447, 2004. 
SOUZA, W.; CARVALHO, T. M. U.; BARRIAS, E. S. Review on Trypanosoma cruzi: Host Cell Interaction. International Journal of Cell Biology. v.2010, p.1-18, 2010.

STEVERDING, D.The History of Chagas Disease.Parasites \& Vectors. v.317(7), p.18, 2014.

STRAUER, B. E.; BREHM, M.; ZEUS, T.; KOSTERING, M.; HERNANDEZ, A.; SORG, R.V.; KOGLER, G.; WERNET, P. Repair of Infarcted Myocardium by Autologous Intracoronary Mononuclear Bone Marrow Cell Transplantation in Humans. Circulation. v.106(15), p.1913-1918, 2002.

TANOWITZ H. B.; MACHADO F.S.; JELICKS L. A.; SHIRANI J.; Carvalho A.C. Perspectives on Trypanosoma cruzi-Induced Heart Disease (Chagas disease). Progress in Cardiovascular Diseases. v.51(6), p.524-539, 2009.

TEICHHOLZ, L. E.; KREULEN, T.; HERMAN, M.V. GORLIN, R. Problems in Echocardiographic Volume Determinations: Echocardiographic-Angiographic Correlations in the Presence or Absence of Asynergy. American of Journal Cardiology. v.37(1), p.7-11, 1976.

TEIXEIRA, A.R.L.; LACAVA, Z.G.M.; SANTANA, J. M. \& LUNA, H. Insertion of Trypanosoma cruzi DNA in the Genome of Mammal Host Cell Through Infection. Rev. Soc. Bras. Med. Trop. v.24(1), p.55-58, 1991.

TEIXEIRA, A. R. L.; ARGAÑARAZ, E.R.; FREITAS, Jr.; LACAVA, Z. G. M.; SANTANA,J. M. \& LUNA, H. Possible Integration of Trypanosoma cruzi kDNA Minicircles Into the Host Cell Genome by Infection. Mut.Res. v.305, p.197-209, 1994.

TEIXEIRA, A. R. L.; HECTH, M. M.; GUIMARO, M.C.; SOUSA, A. O.; NITZ, N. Pathogenesis of Chagas' Disease: Parasite Persistence and Autoimmunity. Clinical Microbiology Reviews. v.24(3), p.592-630, 2011 a.

TEIXEIRA, A. R. L.; GOMES, C.; NITZ, N.; SOUSA, A.O.; ALVES, R.M.; GUIMARO, M.C.; CORDEIRO, C.; BERNAL, F.M.; ROSA, A.C.; HEJNAR, J.; LEONARDECZ, E.; HECHT, M.M. Trypanosoma Cruzi in the Chicken Model: Chagas-Like Heart Disease in the Absence of Parasitism. PLoS Neglected Tropical Disease. v.5(3), p.1-18, 2011b.

TEIXEIRA, A.R.L; NITZ, N; BERNAL, F. M.; HECHT, M. M. Parasite Induced Genetically Driven Autoimmune Chagas Heart Disease in the Chicken Model. Journal of Visualized Experiments. v.65(3716), p.1-9, 2012.

TEIXEIRA, A. R. L; NITZ, N.; GUIMARO, M. C.; GOMES, C.; SANTOS-BUCH, C. A. Chagas disease. Postgrad Med. J. v.82(974), p.788-798, 2006a.

TEIXEIRA, A. R. L.; NASCIMENTO, R. J.; STURM, N. R. Evolution and Pathology in Chagas Disease - a Review.Mem. Inst. Oswaldo Cruz. v.101(5), p. 463-491, 2006b. 
TEIXEIRA, M. G. L. C. Doença de Chagas. Estudo da Forma Aguda Inaparente. Dissertação. Universidade Federal do Rio de Janeiro, Rio de Janeiro, 1997.

URBINA, J. A.; DOCAMPO, R. Specific Chemotherapy of Chagas Disease: Controversies and Advances. Trends in Parasitology. v.19(11), p.495-501, 2003.

VALENTE, S. A. S.; VALENTE, V. C.; NETO, H. F. Considerations on the Epidemiology and Transmission of Chagas Disease in the Brazilian Amazon. Mem. Inst. Oswaldo Cruz, v.94(1), p.395-398, 1999.

VEXENAT, AC. Diagnóstico Sorológico Diferencial de Infecções Causadas por Trypanosoma cruzi, Leishmania (Viannia) braziliensis, Leishmania chagasi e Outras Doenças Crônicas. Dissertação. Universidade de Brasília, 1993.

VIA, S. Natural Selection in Action During Speciation. Proc Natl Acad Sci U.S.A. v.106(1), p.9939-9946, 2009.

VILAS-BOAS, F.; FEITOSA, G. S.; SOARES, M. B. P.; PINHO-FILHO, J. A.; MOTA, A.; ALMEIDA, A. J. G.; CARVALHO, C.; CARVALHO, H. G.; OLIVEIRA, A. D. SANTOS, R. R. Bone Marrow Cell Transplantation to the Myocardium of a Patient with Heart Failure Due to Chagas Disease. Arq Bras Cardiol, v.82(2), p.185187, 2004.

VINHAES, M. C.; OLIVEIRA, S. V.; REIS, O. O.; , SOUSA, A. C. L.; SILVA, R. A.; OBARAC, M. T.; BEZERRA, C. M.; COSTA, V. M. C.; ALVES, R. V.; GURGELGONÇALVES, R. Assessing the Vulnerability of Brazilian Municipalities to the Vectorial Transmission of Trypanosoma cruzi Using Multi-Criteria Decision Analysis. Acta Tropica, v.137, p.105-110, 2014.

WORLD HEALTH ORGANIZATION.Control of Chagas Disease.Second Report of a WHO Expert Committee. p. 905, 2002.

WORLD HEALTH ORGANIZATION.Reporte Sobre la Enfermedad de Chagas.Grupo de Trabajo Científico.2005 - Atualizado em 2007.

WORLD HEALTH ORGANIZATION.Consultation on International Biological Reference Preparations for Chagas Diagnostic Tests. Who Techincal Report Series, Geneva, p.2-3, jul. 2007.

WORLD HEALTH ORGANIZATION. Chagas Disease (American Trypanosomiasis). Fact Sheet. v.340. Atualizado em Março de 2015.

ZINGALES, B.; MILES, M. A.; CAMPBELL, D. A.; TYBAYRENC, M.; MACEDO, A. M.; TEIXEIRA, M. M. G.; SCHIJMAN, A. G.; LLEWELLYN, M. S.; LAGES-SILVA, E.; MACHADO, C. R.; ANDRADE, S, G.; STURM, N. R. The Revised Trypanosoma cruzi Subspecific Nomenclature: Rationale, Epidemiological Relevance and Research Applications. Infection, Genetics and Evolution. v.12, p.240-253, 2012. 


\section{Apêndice}

Mediana das medidas ecocardiográficas para cada variável dos quatro grupos experimentais das aves $(n=5)$ antes, 3 meses e 10 meses após transplante de medula óssea.

\begin{tabular}{|c|c|c|c|c|c|c|c|c|c|c|c|c|}
\hline \multirow[t]{2}{*}{ Variável* $^{*}$} & \multicolumn{4}{|c|}{ Antes do tratamento } & \multicolumn{4}{|c|}{3 meses após tratamento } & \multicolumn{4}{|c|}{10 meses após tratamento } \\
\hline & G1 & G2 & G3 & G4 & G1 & G2 & G3 & G4 & G1 & G2 & G3 & G4 \\
\hline PLVEd (cm) & 0,41 & 0,44 & 0,39 & 0,35 & 0,39 & 0,36 & 0,43 & 0,37 & 0,34 & 0,32 & 0,33 & 0,35 \\
\hline SIVd (cm) & 0,36 & 0,32 & 0,26 & 0,25 & 0,30 & 0,35 & 0,32 & 0,28 & 0,32 & 0,32 & 0,28 & 0,25 \\
\hline DIVEd (cm) & 1,08 & 1,16 & 1,06 & 1,11 & 1,35 & 1,16 & 1,63 & 1,67 & 1,25 & 1,35 & 1,19 & 1,30 \\
\hline SIVs (cm) & 0,51 & 0,47 & 0,43 & 0,44 & 0,52 & 0,49 & 0,56 & 0,41 & 0,48 & 0,50 & 0,46 & 0,36 \\
\hline DIVEs (cm) & 0,62 & 0,61 & 0,48 & 0,62 & 0,85 & 0,63 & 0,94 & 1,34 & 0,72 & 0,77 & 0,70 & 0,88 \\
\hline PLVEs (cm) & 0,56 & 0,55 & 0,52 & 0,48 & 0,57 & 0,58 & 0,66 & 0,56 & 0,57 & 0,61 & 0,47 & 0,42 \\
\hline FS (\%) & 43,75 & 47,56 & 55,81 & 45,02 & 37,05 & 44,61 & 42,45 & 21,75 & 44,62 & 45,25 & 42,30 & 23,72 \\
\hline EF (\%) & 79,38 & 82,93 & 89,43 & 79,83 & 71,23 & 80,40 & 76,69 & 48,22 & 79,85 & 80,12 & 77,29 & 52,02 \\
\hline
\end{tabular}

* Espessura da Parede Livre do Ventrículo Esquerdo em diástole (PLVEd); Espessura do Septo Interventricular em diástole (SIVd); Diâmetro Interno do Ventrículo Esquerdo em diástole (DIVEd); Espessura do Septo Interventricular em sístole (SIVs); Diâmetro Interno do Ventrículo Esquerdo em sístole (DIVEs); Espessura da Parede Livre do Ventrículo Esquerdo em sístole (PLVEs); Fração de Encurtamento (FS) e Fração de Ejeção (EF). 
